\title{
Ruthenium-Aminoallenylidene Complexes from Butatrienylidene Intermediates via an Aza-Cope Rearrangement: Synthetic, Spectroscopic, Electrochemical, Spectroelectrochemical, and Computational Studies
}

\author{
Rainer F. Winter* and Karl-Wilhelm Klinkhammer \\ Institut für Anorganische Chemie der Universität Stuttgart, Pfaffenwaldring 55, \\ D-70569 Stuttgart, Germany \\ Stanislav Záliš* \\ J . Heyrovský Institute of Physical Chemistry, Academy of Sciences of the Czech Republic, \\ Dolejškova 3, Prague, Czech Republic
}

Received October 31, 2000

\begin{abstract}
Ruthenium-aminoallenylidene complexes trans- $\left[\mathrm{Cl}\left(\mathrm{L}_{2}\right)_{2} \mathrm{RuCCC}\left(\mathrm{NR}_{2}\right) \mathrm{CH}_{2} \mathrm{R}^{\prime}\right]^{+} \mathrm{EF}_{6}{ }^{-}(\mathbf{4 a}-$ f; $\mathrm{E}=\mathrm{P}, \mathrm{Sb}, \mathrm{L}_{2}=$ chelating diphosphine) are accessible from the respective dichloro precursors, $\mathrm{NaEF}_{6}$, butadiyne, and an allylic amine in a one-pot procedure. The reactions proceed via the primary butatrienylidene intermediate trans- $\left[\mathrm{Cl}\left(\mathrm{L}_{2}\right)_{2} \mathrm{Ru}=\mathrm{C}=\mathrm{C}=\mathrm{C}=\mathrm{CH}_{2}\right]^{+}$ and the initial addition products trans- $\left[\mathrm{Cl}\left(\mathrm{L}_{2}\right)_{2} \mathrm{Ru}-\mathrm{C} \equiv \mathrm{CC}\left(\mathrm{NR}_{2} \mathrm{R}^{\prime}\right)=\mathrm{CH}_{2}\right]^{+}$via an Aza-Cope type rearrangement. Amine adducts have been isolated for (dimethylamino)-2-pentyne (3f) and 1-methyl-1,2,5,6-tetrahydropyridine (3g). The former cleanly converts to its aminoallenylidene isomer upon warming. All products have been characterized by various spectroscopic techniques, including NMR, IR, and UV/vis spectroscopy and cyclic voltammetry; complex $\mathbf{4 b}$ was also characterized by X-ray crystallography. Most notable are the considerable bond length alternations along the unsaturated $C_{3}$ ligand and the trigonalplanar nitrogen, indicative of its $\mathrm{sp}^{2}$ character. Aminoallenylidene complexes of this type are best described as a hybrid between true cumulenic and iminium alkynyl resonance forms, with major contributions of the latter, as is also evident from the high energy barriers for rotation around the iminium type $\mathrm{C}=\mathrm{N}$ bond. The effect of the electron density on the metal on the spectroscopic and electrochemical properties of the cations in $\mathbf{4}$ has been probed for the dimethylallylamine-derived complexes trans- $\left[\mathrm{Cl}\left(\mathrm{L}_{2}\right)_{2} \mathrm{RuCCC}\left(\mathrm{NMe}_{2}\right) \mathrm{C}_{4} \mathrm{H}_{7}\right]^{+} \mathrm{EF}_{6}{ }^{-}(\mathbf{4 a}-\mathbf{c})$, which only differ in the nature of the chelating diphosphine ligand. Aminoallenylidene complexes 4 undergo reversible one-electron oxidation. In contrast, their reduction is irreversible at room temperature but partially reversible at temperatures between 233 and $195 \mathrm{~K}$. The spectroscopic changes accompanying oxidation were monitored by in situ UV/ vis, IR, and EPR techniques. DFT calculations have been performed on the model complexes trans- $\left[\mathrm{Cl}\left(\mathrm{L}_{2}\right)_{2} \mathrm{Ru}=\mathrm{C}=\mathrm{C}=\mathrm{C}=\mathrm{CH}_{2}\right]^{+}$and trans- $\left[\mathrm{Cl}\left(\mathrm{L}_{2}\right)_{2} \mathrm{RuC}{ }_{3}\left\{\mathrm{~N}\left(\mathrm{CH}_{3}\right)_{2}\right\} \mathrm{CH}_{3}\right]^{+}$. Our results explain the regioselectivity of nucleophilic addition to the proposed butatrienylidene intermediate and the spectroscopic and el ectrochemical properties of aminoallenylidene complexes 4. Both orbital and steric effects are equally important in the regioselective addition to $C_{3}$. The cal culations further indicate primarily metal-based oxidation and ligand-based reduction of complexes 4, in accordance with experimental observations. They also let us assign the experimental UV/vis bands and the two main IR absorptions in the $2000-1500 \mathrm{~cm}^{-1}$ region.
\end{abstract}

\section{Introduction}

Within the context of transition-metal complexes containing higher homologues of the carbene ligand, the chemistry of butatrienylidene complexes has emerged as a fascinating research field on its own right. In

* To whom correspondence should be addressed. R.F.W.: e-mail, winter@iac.uni-stuttgart.de; fax, +49711 685 4065. S.Z.: e-mail, stanislav.zalis@j-inst.cas.cz; fax, +4202 8582307. principle, a cumulated $\mathrm{C}_{4}$ ligand can function in several bonding modes, either as a bridging ligand in dimetal complexes or higher nuclearity transition-metal clusters or in mononuclear complexes in either the side-on $\left(\eta^{2}\right)$ or end-on $\left(\eta^{1}\right)$ binding mode. Cumulenic "naked" $\mathrm{C}_{4}$ bridges as part of a more extended 1,6-dimetallahexapentaenylidene are present in the dianionic molybdenum and tungsten complexes $\left[\left\{\mathrm{Tp}^{\prime}(\mathrm{CO})_{2} \mathrm{M}\right\}_{2}\left(\mu, \eta^{1}: \eta^{1-}\right.\right.$ $\left.\left.\mathrm{C}_{4}\right)\right]^{2-}\left(\mathrm{Tp}^{\prime}=\right.$ hydridotris(3,5-dimethylpyrazolyl)borate, 
$M=M o, W)^{1}$ or in various oxidized forms of butadiynediyl-bridged dirhenium, ${ }^{2 a-c}$ dimanganese, ${ }^{2 \mathrm{~d}}$ diiron, ${ }^{3}$ or diruthenium ${ }^{4}$ complexes. Cumulenic butatrienylidene entities have also been invoked as significant contributors in a trioxidized, diynediyl-derived diiron complex ${ }^{5}$ and the zwitterionic resonance form of a $\mathrm{C}_{4}$-bridged rhenium-triosmium cluster. ${ }^{6}$ The diiron complexes $\left[\left\{\mathrm{Cp}^{*} \mathrm{~L}_{2} \mathrm{Fe}\right\}=\mathrm{C}=\mathrm{C}=\mathrm{C}=\mathrm{C}(\mathrm{R})\left\{\mathrm{Fe}(\mathrm{CO})_{2} \mathrm{Cp}^{*}\right\}\right] \quad\left(\mathrm{L}={ }^{\mathrm{i}} \mathrm{Pr}_{2^{-}}\right.$ $\mathrm{PC}_{2} \mathrm{H}_{4} \mathrm{PiPr}_{2}$, dppe; $\mathrm{R}=\mathrm{H}, \mathrm{Me}$ ), where butatrienylidene ligands span two different iron centers, were reported to arise from the protonation or methylation of the respective diynediyl-bridged precursor. ${ }^{7}$ Butatrienylidene ligands $\mathrm{C}_{4} \mathrm{RH}\left(\mathrm{R}=\mathrm{SiMe}_{3}, \mathrm{H}\right)$ have al so been found in pentanuclear ruthenium clusters, where they employ two $\mathrm{C}=\mathrm{C} \pi$ bonds for additional side-on coordination and thus act as six-electron donors. ${ }^{8}$

Two more general approaches to stable mononuclear complexes with an end-on butatrienylidene ligand are now available. The first consists of the activation of terminal alkynyl keto complexes $\{\mathrm{M}\}-\mathrm{C} \equiv \mathrm{CC}(\mathrm{O}) \mathrm{CHRR}^{\prime}$ (or enol ethers thereof) with a formally $\mathrm{OH}$-abstracting agent such as trifluoroacetic acid anhydride. ${ }^{9,10}$ This method, as originally introduced by Selegue, ${ }^{10}$ has ultimately rendered $\mathrm{Cl}\left(\mathrm{P}^{\mathrm{i}} \mathrm{Pr}_{3}\right)_{2} \mathrm{I} \mathrm{r}=\mathrm{C}=\mathrm{C}=\mathrm{C}=\mathrm{CPh}_{2}$ as the first stable butatrienylidene complex that also lends itself to structural characterization by X-ray methods. ${ }^{9}$ This compound owes its stability to protection of the terminal $\mathrm{sp}^{2}$ carbon by aryl substituents, which is also the key to stable pentatetraenylidene complexes. ${ }^{11} \mathrm{~A}$ more direct access route consists of the activation of terminal diynes by coordinatively unsaturated yet electron-rich transition-metal fragments. ${ }^{12-15}$ This methodology is akin to the well-known alkyne to vinylidene tautomerization. ${ }^{16}$ Although this approach has not

(1) Woodworth, B. E.; White, P. S.; Templeton, J . L. J . Am. Chem. Soc. 1997, 119, 828

(2) (a) Seyler, J. W.; Weng, W.; Zhou, Y.; Gladysz, J . A. Organome tallics 1993, 12, 3802. (b) Zhou, Y.; Seyler, J . W.; Weng, W.; Arif, A. M.; Gladysz, J. A. J . Am. Chem. Soc. 1993, 115, 8509. (c) Brady, M.; Weng, W.; Zhou, Y.; Seyler, J . W.; Amoroso, A. J .; Arif, A. M.; Böhme M.; Frenking, G.; Gladysz, J . A. J. Am. Chem. Soc. 1997, 119, 775. (d) Kheradmandan, S.; Heinze, K.; Schmalle, H. W.; Berke, H. Angew. Chem. 1999, 111, 2412; Angew. Chem., Int. Ed. 1999, 38, 2270.

(3) Coat, F.; Guillemot, M.; Paul, F.; Lapinte, C. J . Organomet. Chem. 1999, 578, 76.

(4) (a) Bruce, M. I.; Denisovich, L. I.; Peregudova, S. M.; Ustynyuk, N. A. Mendeleev Commun. 1996, 200. (b) Bruce, M. I.; Low, P. J . Costuas, K.; Halet, J .-F.; Best, S. P.; Heath, G. A. J . Am. Chem. Soc 2000, 122, 1949

(5) Guillemot, M.; Toupet, L.; Lapinte, C. Organometallics 1998, 17 1928. 629

(6) Falloon, S. B.; Arif, A. M.; Gladysz, J . A. Chem. Commun. 1997,

(7) Coat, F.; Guillemot, M.; Paul, F.; Lapinte, C. J . Organomet. Chem. 1999, 578, 76.

(8) (a) Adams, C. J .; Bruce, M. I.; Skelton, B. W.; White, A. H. J Chem. Soc., Chem. Commun. 1996, 2663. (b) Adams, C. J ; Bruce, M.

I.; Skelton, B. W.; White, A. H. J . Organomet. Chem. 1999, 584, 254.

(9) Ilg, K.; Werner, H. Angew. Chem. 2000, 112, 1991; Angew. Chem. Int. Ed. 2000, 39, 1632.

(10) Lomprey, J . R.; Selegue, J . P. Organometallics 1993, 12, 616. (11) (a) Romero, A.; Peron, D.; Dixneuf, P. H. J . Chem. Soc., Chem. Commun. 1990, 1410. (b) Touchard, D.; Haquette, P.; Daridor, A. Toupet, L.; Dixneuf, P. H. J . Am. Chem. Soc. 1994, 116, 11157. (c) Lass, R. W.; Steinert, P.; Wolf, J .; Werner, H. Chem. Eur. J . 1996, 2 , 19. (b) Kovacik, I.; Laubender, M.; Werner, H. Organometallics 1997 16, 5607.

(12) (a) Bruce, M. I.; Hinterding, P.; Low, P. J .; Skelton, B. W.; White, A. H. J . Chem. Soc., Chem. Commun. 1996, 1009. (b) Bruce, M. I.; Hinterding, P.; Low, P.J .; Skelton, B. W.; White, A. H. J . Chem. Soc., Dalton Trans. 1998, 467. (c) Bruce, M. I.; Hinterding, P.; Ke, M.; Low, P.J .; Skelton, B. W.; White, A. H.J . Chem. Soc., Chem. Commun 1997, 715. (d) Bruce, M. I.; Ke, M.; Kelly, B. D.; Low, P. J .; Smith, M E.; Skelton, B. W.; White, A. H. J . Organomet. Chem. 1999, 590, 184201. produced any stable butatrienylidene species to date, the outcome of diverse trapping reactions convincingly supports their presence as reactive intermediates.

With regard to the reactivity of the terminal butatrienylidene ligand, the primary system derived from butadiyne has received the most attention and seems to differ substantially from that of its mono- and disubstituted secondary or tertiary analogues. Its reactivity patterns have initially been rationalized by the alternating of electrophilic $\left(C_{1}, C_{3}\right)$ and nucleophilic $\left(C_{2}\right)$ carbon centers along the cumulenic chain, as was suggested by semiempirical calculati ons. ${ }^{17}$ DFT calculations on the neutral el ectron-poor $d^{6}$ complexes (CO) $5^{-}$ $\mathrm{Cr}=\mathrm{C}_{n}=\mathrm{CH}_{2}(\mathrm{n}=1-8)$, however, showed that polarization of the carbon chain is almost negligible and the observed regioselectivity is explained by frontier orbital control. ${ }^{18}$ Thus, the $\mathrm{C}_{4} \mathrm{H}_{2}$ ligand regioselectively adds aprotic nucleophiles such as amines and phosphines to $\mathrm{C}_{3}, \mathrm{C}_{1}$ being sterically protected by the bulky coligands (usually tertiary phosphines) on the metal.12a,c,13a,d The protic nucleophiles $\mathrm{ER}_{n} \mathrm{H}$ regioselectively add to the terminal $\mathrm{C}=\mathrm{C}$ double bond to give substituted alle nylidene complexes $\left[\{M\}=C=C=C\left(E R_{n}\right) C H_{3}\right]^{n+}\left(E R_{n}=\right.$ $\mathrm{NR}_{2}$, ${ }^{12 a, b} \mathrm{OR}$, ${ }^{12 a, b, 15} \mathrm{SR}$, ${ }^{13 d}$ 2-(N-methylpyrrol $\left.{ }^{12 a, b}\right)$, in which the nucleophilic center is again attached to $C_{3}$. In contrast, a secondary butatrienylidene complex derived from phenylbutadiyne is deprotonated by $\mathrm{NEt}_{3}$ to give the phenyl butadiynyl compl ex, ${ }^{14}$ while the tertiary butatrienylidene complex $\mathrm{Cl}\left(\mathrm{PiPr}_{3}\right)_{2} \mathrm{I}=\mathrm{C}=\mathrm{C}=\mathrm{C}=\mathrm{CPh}_{2}$ adds trifluoroacetic acid to the internal $\mathrm{C}_{2}-\mathrm{C}_{3}$ double bond. ${ }^{9}$

The high synthetic potential of the primary butatrie nylidene intermediates is highlighted by their cycloaddition/cycloreversion sequences with aromatic imines, yielding 4-ethynylquinolidine or vinyl-substituted 1-azabuta-1,3-diene complexes, depending on the substituents on the imine. ${ }^{12 c, d}$ We have already communicated an instance where the transient butenynyl complexes [Cl$\left.\left(\mathrm{L}_{2}\right)_{2} \mathrm{Ru}-\mathrm{C} \equiv \mathrm{CC}\left(\mathrm{NMe}_{2} \mathrm{allyl}\right)=\mathrm{CH}_{2}\right]^{+}$, derived from amine addition to the respective butatrienylidene precursors $\left(\mathrm{L}_{2}=\mathrm{Ph}_{2} \mathrm{PCH}_{2} \mathrm{Ph}_{2}\right.$ (dppm), $\mathrm{Et}_{2} \mathrm{PC}_{2} \mathrm{H}_{4} \mathrm{PEt}_{2}$ (depe)), rearrange under very mild conditions via an Aza-Cope type process to the aminoallenylidene isomers $\left[\mathrm{Cl}\left(\mathrm{L}_{2}\right)_{2} \mathrm{Ru}=\right.$ $\left.\mathrm{C}=\mathrm{C}=\mathrm{C}\left(\mathrm{NMe}_{2}\right) \mathrm{C}_{4} \mathrm{H}_{7}\right]^{+}$. As such, this presents a rare example of a sigmatropic rearrangement occurring within the coordination sphere of a transition-metal

(13) (a) Winter, R. F.; Hornung, F. M. Organometallics 1997, 16 4248. (b) Winter, R. F. J . Chem. Soc., Chem. Commun. 1998, 2209. (c) Winter, R. F. Eur. J . Inorg. Chem. 1999, 2121. (d) Winter, R. F.; Hornung, F. M. Organometallics 1999, 18, 4005.

(14) Haquette, P.; Touchard, D.; Toupet, D.; Dixneuf, P. J . Organomet. Chem. 1998, 565, 67.

(15) Guillaume, V.; Thominot, P.; Coat, F.; Mari, A.; Lapinte, C. J Organomet. Chem. 1998, 565, 75.

(16) (a) Lomprey, J . R.; Selegue, J . P. J . Am. Chem. Soc. 1992, 114, 5518. (b) Bullock, R. M. J . Chem. Soc., Chem. Commun. 1989, 165. (c) Haquette, P.; Pirio, N.; Toupet, L.; Dixneuf, P. H. J . Chem. Soc., Chem. Commun. 1993, 163. (d) Touchard, D.; Haquette, P.; Pirio, N.; Toupet, L.: Dixneuf, P. H. Organometallics 1993, 12, 3132. (e) Werner, H. Rappert, T.; Wiedemann, R.; Wolf, J .; Mahr, N. Organometallics 1994 13, 2721 (f) Whittall, I. R.; Humphrey, M. G.; Hockless, D. C. R.; Skelton, B. W.; White, A. H. Organometallics 1995, 14, 3970. (g) de los Ríos, I.: Jiménez-Tenorio, M.: Puerta, M. C.: Valerga, P. J. Am. Chem. Soc. 1997, 119, 6529. (h) Werner, H.; Lass, R. W.; Gevert, O.; Wolf, J . Organometallics 1997, 16, 4077.

(17) (a) Kostić, N. M.: Fenske, R. F. Organometallics 1992, 1, 974 (b) Schilling, B. E. R.; Hoffmann, R.; Lichtenberger, D. L. J . Am. Chem. Soc. 1979, 101, 585. 1115 
fragment. ${ }^{19}$ Herein we present a full account of this work, including (i) an extension of this reaction to propargylic and functionalized allylic amines, (ii) the rearrangement of an isolable primary adduct to its aminoallenylidene isomer, (iii) full spectroscopic and electrochemical characterization of the products, (iv) the UV/vis, IR, and EPR spectroscopic characterization of some of the oxidized forms derived from the monocationic aminoallenylidene complexes, and (v) the results of DFT calculations on the $\left[\mathrm{Cl}\left(\mathrm{PH}_{3}\right)_{4} \mathrm{Ru}=\mathrm{C}=\mathrm{C}=\mathrm{C}=\right.$ $\left.\mathrm{CH}_{2}\right]^{+}$and $\left[\mathrm{Cl}\left(\mathrm{PH}_{3}\right)_{4} \mathrm{RuCCC}(\mathrm{NMe})_{2} \mathrm{CH}_{3}\right]^{+/ 2+}$ model complexes, which complement previous calculations on butatrienylidene ${ }^{17,18}$ and related allenylidene ${ }^{20}$ compounds and aid in rationalizing the observed reactivity and spectroscopic properties of these systems in their closed- and open-shell forms.

\section{Results and Discussion}

Synthesis. We ${ }^{13 a, d}$ and others ${ }^{12 a, b}$ have previously reported on the trapping of ruthenium-butatrienylidene intermediates $\left[\{\mathrm{Ru}\}=\mathrm{C}=\mathrm{C}=\mathrm{C}=\mathrm{CH}_{2}\right]^{+}(\{\mathrm{Ru}\}=\mathrm{CpRu}$ $\left.\left(\mathrm{PPh}_{3}\right)_{2}{ }^{12 a, b}\right)$ and trans-[Cl(dppm) $\left.)_{2} \mathrm{Ru}\right]\left(\mathrm{dppm}=\mathrm{Ph}_{2} \mathrm{CH}_{2}-\right.$ $\left.\mathrm{PPh}_{2}{ }^{13 a}, \mathrm{~d}\right)$ generated in situ from the respective chloro precursors and excess butadiyne with tertiary amines. The stable 2-ammoniobutenynyl complexes [Cl$\left.(\mathrm{dppm})_{2} \mathrm{Ru}-\mathrm{C} \equiv \mathrm{CC}\left(\mathrm{NR}_{2} \mathrm{R}^{\prime}\right)=\mathrm{CH}_{2}\right]^{+}$(3) are obtained from a broad variety of aliphatic or benzylic amines or electron-rich pyridines by regioselective addition to carbon atom $\mathrm{C}_{3}$ of the cumulated $\mathrm{C}_{4}$ chain. If $\mathrm{R}^{\prime}$ is an allylic moi ety, the primary addition products constitute quaternary vinyl allylammonium salts. Their purely organic counterparts may readily undergo 3-Aza-Cope (or 3-Amino-Claisen) rearrangements to their 1-azonia1,5-hexadiene isomers. Although in many cases this process requires substantial thermal activation, such rearrangements have occasional ly been observed under ambient or subambient conditions. ${ }^{21}$ We have recently communicated that the dimethylallylamine-derived adducts $\left[\mathrm{Cl}\left(\mathrm{L}_{2}\right)_{2} \mathrm{Ru}-\mathrm{C} \equiv \mathrm{CC}\left(\mathrm{NMe}_{2} \mathrm{C}_{3} \mathrm{H}_{5}\right)=\mathrm{CH}_{2}\right]^{+}\left(\mathrm{L}_{2}=\mathrm{Ph}_{2^{-}}\right.$ $\mathrm{PCH}_{2} \mathrm{Ph}_{2}$ (dppm), $\mathrm{Et}_{2} \mathrm{PC}_{2} \mathrm{H}_{4} \mathrm{PEt}_{2}$ (depe)) also behave in this manner, providing rare examples of a sigmatropic rearrangement within the coordination sphere of a transition-metal complex. ${ }^{19}$ The overall reaction sequence, i.e., addition of an aprotic, allyl-substituted nucleophile to butatrienylidene intermediates $\mathbf{2}$ followed by Cope- or Claisen-type rearrangements also constitutes one possible route to novel thio-13c or selenosubstituted $^{22}$ allenylidene complexes. We have now extended this protocol to a broader variety of allylic amines and a propargylic amine to expl ore its scope and limitations.

cis- $\mathrm{RuCl}_{2}(\mathrm{dppm})_{2}$, excess butadiyne, and an appropriate allylic amine produce the respective amino-substi-

(19) Barrett, A. G. M.; Carpenter, N. E. Organometallics 1987, 6 , 2249.

(20) (a) Cadierno, V.; Gamasa, M. P.; Gimeno, J .; González-Cueva, M.; Lastra, E.; Borge, J .; García-Granda, S.; Pérez-Carreňo, E. Organometallics 1996, 15, 2137. (b) Esteruelas, M. A.; Gómez, A. V.; López, A. M.; Modrego, J .; Oňate, E. Organometallics 1997, 16, 5826. (c) Baya M.; Crochet, P.; Esteruelas, M. A.; Gutiérrez-Puebla, E.; López, A. M.; Modrego, J .; Oñate, E.; Vela, N. Organometallics 2000, 19, 2585. (d) Berke, H.; Huttner, G.; von Seyerl, J. Z. Naturforsch., B 1981, 36B, 1277.

(21) (a) Vedejs, E.; Gingras, M. J. Am. Chem. Soc. 1994, 116, 579 (b) Walters, M. A.; Hoem, A. B.; McDonough, C. S. J . Org. Chem. 1996, 55. (c) Walters, M. A. J . Org. Chem. 1996, 978.

(22) Hartmann, S.; Winter, R. F.; Scheiring, T.; Wanner, M. J . Organomet. Chem., in press. tuted allenylidene complexes $\mathbf{4 a , d , e ~ i n ~ g o o d ~ t o ~ e x c e l l e n t ~}$ yields in a one-pot synthesis with the concomitant formation of a ruthenium-carbon, a carbon-nitrogen, and a carbon-carbon bond and the cleavage of the nitrogen-allyl carbon bond (see Scheme 1). Simple allylic amines were successfully employed, but tris(2methyl)allylamine failed to give any isolable product, most likely due to its steric bulk. Likewise, attempts to employ 1-benzyl-3-pyrroline as the trapping reagent gave a mixture of products from which the known cis$\left[(\mathrm{dppm})_{2} \mathrm{RuCl}\left(\mathrm{CH}_{3} \mathrm{CN}\right)\right]^{+}$slowly crystallized. Since this complex is formed in the absence of any other nitrogen source, we feel that the nitrile ligand arises from the degradation of the amine. To probe for the effect of the electron density on the metal on the spectroscopic and electrochemical properties of complexes 4, dimethylalIylamine-derived analogues of $\mathbf{4 a}$ with $L_{2}=$ dppe (4b), depe (4c) were also prepared, whereas the respective 1,2-bis(dicyclohexylphosphino)ethane derivative could not be obtained in this manner.

The primary adducts trans-[Cl(dppm $)_{2} \mathrm{Ru}-\mathrm{C} \equiv \mathrm{CC}$ $\left.\left(\mathrm{NR}_{2} \mathrm{R}^{\prime}\right)=\mathrm{CH}_{2}\right]^{+}$were frequently identified at some early stage of these reactions by virtue of their characteristic IR band at $2032-2038 \mathrm{~cm}^{-1}, 13 a, \mathrm{~d}$ but not isolated. This proved, however, possible for (dimethylamino)pent-2yne as an example of a propargylic amine and 1-methyl1,2,5,6-tetrahydropyridine, where the allylic moiety is confined to a heterocyclic ring. The respective 2 -ammoni obutenynyl complexes $\mathbf{3 f , g}$ were obtained in moderate yields after chromatographic workup. At somewhat elevated temperatures $\mathbf{3 f}$ (above $60^{\circ} \mathrm{C}$ ) and $\mathbf{3 g}$ (above $85{ }^{\circ} \mathrm{C}$ ) react smoothly to the rearranged counterpart $4 \mathbf{f}$ and an as yet unidentified product arising from 3g. No clean rearrangement occurred for the ammoniobutenynyl complexes trans-[Cl(dppm $)_{2} \mathrm{Ru}-\mathrm{C} \equiv \mathrm{CC}$ $\left.\left(\mathrm{NMe}_{2} \mathrm{CH}_{2} \mathrm{C}_{6} \mathrm{H}_{4} \mathrm{R}\right)=\mathrm{CH}_{2}\right]^{+}\left(\mathrm{R}=\mathrm{H}\right.$, 3-OMe), ${ }^{13 \mathrm{~d}}$ where the aromatic double bond constitutes the allylic component. This contrasts to the numerous examples for thermally induced Amino-Claisen rearrangements of allyl-substituted anilines in organic chemistry, where the aromatic system serves as the vinylic part. ${ }^{23} 31 \mathrm{P}$ NMR spectra recorded during the gradual rearrangement of $\mathbf{3 f}$ to $\mathbf{4 f}$ at $80^{\circ} \mathrm{C}$ are shown in Figure 1 . Preliminary investigations show this process to obey simple first-order kinetics, as expected for an intramolecular reaction.

Our synthesis of the dppe complex $\mathbf{4 b}$ deserves some special comment. Best results were achieved when the pure trans isomer was reacted with $\mathrm{NaSbF}_{6}$ (or $\mathrm{NaPF}_{6}$ ) in o- $\mathrm{C}_{6} \mathrm{H}_{4} \mathrm{Cl}_{2}$ at room temperature. This is quite remarkable in that the trans isomer is usually regarded as being inert toward chloride dissociation under these conditions. ${ }^{24}$ The more reactive cis isomer gave $\mathbf{4 b}$ in moderate yield, while the use of $\mathrm{AgPF}_{6}, \mathrm{AgCF}_{3} \mathrm{SO}_{3}$, and $\mathrm{TIPF}_{6}$ as halide abstracting agents gave only intractable mixtures. Pure trans- $\mathrm{RuCl}_{2}$ (dppe) $)_{2}$ is conveniently obtained in high yield, as detailed in the Experimental Section, whereas the cis isomer is al ways contaminated with the trans form. ${ }^{25}$

(23) (a) Bennett, G. B. Synthesis 1977, 589. (b) Heimgartner, H. Hansen, H.-J .; Schmid, H. Adv. Org. Chem. 1979, 9, 655. (c) Lutz, R. P. Chem. Rev. 1984, 84, 205.

(24) Chin, B.; Lough, A. I: Morris, R. H.; Schweitzer, C. T.; D'Agostino, C. Inorg. Chem. 1994, 33, 6278.

(25) Bautista, M.; Capellani, E. P.; Drouin, S. D.; Morris, R. M.; Schweitzer, C. T.; Sella, A.; Zubkowski, J . J . Am. Chem. Soc. 1991, $113,4876$. 


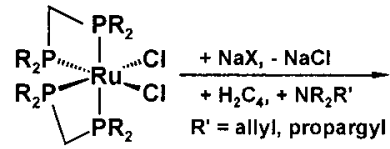

1

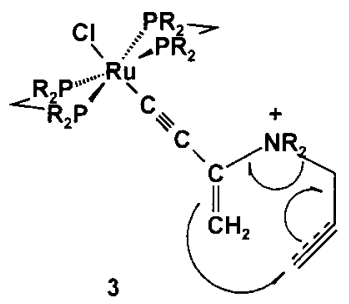

$\underline{[3,3] \text { Aza-Cope }}$

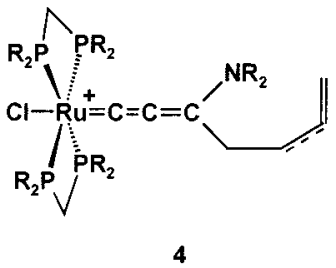

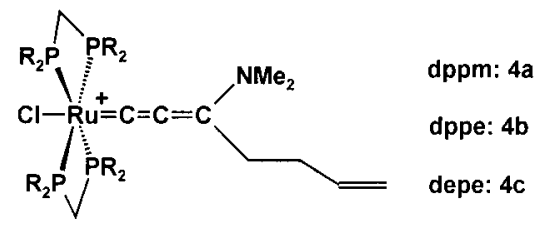<smiles>C=C(C#CC(Cl)(P(c1ccccc1)c1ccccc1)P(=O)(c1ccccc1)c1ccccc1)[NH2+]CC=CCC</smiles>

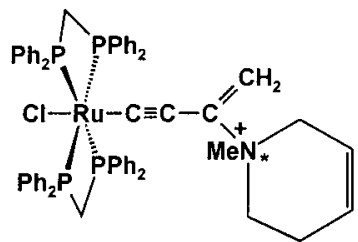

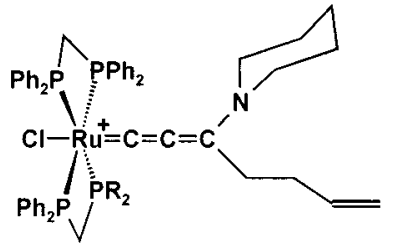<smiles>C=CC(CNC)CC(=C=C=[P+](Cl)(c1ccccc1)c1ccccc1)CP(c1ccccc1)c1ccccc1</smiles><smiles>CCC(C)CC(C)=C=C=[N+](Cc1ccccc1)[PH](Cl)(c1ccccc1)c1ccccc1</smiles>

$4 \mathbf{f}$

medium-intensity IR stretch of the modified alkynyl ligand at ca. $2035 \mathrm{~cm}^{-1}$ and the two doublet signals for the olefinic methylene protons at about $\delta 3.9$ and 4.7 ppm with a geminal coupling of $3 \mathrm{~Hz}$ in the ${ }^{1} \mathrm{H}$ NMR spectrum. The resonance signals of the carbon atoms of the unsaturated $\mathrm{C}_{4}$ chain appear at ca. 146-148 ppm as a quintet with a $\mathrm{P}-\mathrm{C}$ coupling constant of $14 \mathrm{~Hz}\left(\mathrm{C}_{1}\right)$, a singlet at ca. 108 ppm for $\mathrm{C}_{4}$, and a broad signal at ca. 55 ppm assigned to the nitrogen-substituted $C_{3} \cdot C_{2}$ is observed as a broad, unresolved signal for 3 at $\delta 98.5$ ppm but appears as a well-resolved quintet with J $\mathrm{P}-\mathrm{C}$ $=1.84 \mathrm{~Hz}$ at $\delta 95.7 \mathrm{ppm}$ for the tetrahydropyridine derivative $\mathbf{3 g}$. The signals of the additional alkynyl and olefinic carbons in the ammonium side chain are readily identified by appropriate DE PT experiments at $\delta 68$ and $94 \mathrm{ppm}(\mathrm{C} \equiv \mathrm{C}, 3 \mathbf{3 f})$ and $\delta 120$ and $125 \mathrm{ppm}(\mathrm{HC}=\mathrm{CH}$, 3g).

To adequately describe the bonding within aminoallenylidene complexes, two different resonance forms have to be invoked, as illustrated in the Chart 1: the true cumulene type structure $\mathbf{A}$ and the alkynyl type resonance form $\mathbf{B}$. The relative contribution of each individual resonance forms depends, inter alia, on the nature of the heteroatom and its ability to support a

Spectroscopy. Complexes $\mathbf{3 f , g}$ exhibit the spectroscopic features that we al ready established for this class of compounds. ${ }^{13 a, d}$ Of special diagnostic value are the 


\section{Chart 1}

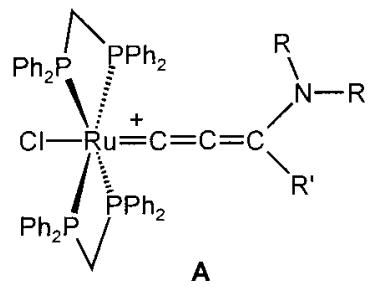

positive charge. ${ }^{13 \mathrm{C}}$ In comparison to other substituents $E R_{n}(E=C, n=3 ; E=N, n=2 ; E=0, S, S e, n=1)$, nitrogen has special donor qualities, enhancing the importance of the iminiumalkynyl resonance form $\mathbf{B}$. Substantial contributions of iminium type resonance forms are frequently invoked whenever electron-rich amino groups are in resonance with $\mathrm{M}=\mathrm{C}$ double bonds such as in aminocarbene complexes, 30 aminoallenylidene complexes as their "cumul ogous" counterparts, 13a,d,27-29 amino-substituted vinyl carbene complexes [Cp(CO)( $\mathrm{Pi}^{\mathrm{i}}$ $\left.\left.\mathrm{Pr}_{3}\right) \mathrm{Ru}=\mathrm{C}\left(\mathrm{NRR}^{\prime}\right) \mathrm{CH}=\mathrm{CPh}_{2}\right]^{+}$(which, in fact, are more adequately described as the 1-azoniabutadienyl complexes $\left.\left[\mathrm{Cp}(\mathrm{CO})\left(\mathrm{P}^{\mathrm{i}} \mathrm{Pr}_{3}\right) \mathrm{Ru}-\mathrm{C}\left(=\mathrm{NRR}^{\prime}\right) \mathrm{CH}=\mathrm{CPh}_{2}\right]^{+}\right),{ }^{31}$ or 4-amino-1-metalla-1,3,5-trienes. ${ }^{32}$ As will be detailed below, our aminoal lenylidene complexes closely adhere to these expectations.

IR spectra of aminoallenylidene complexes $\mathbf{4}$ display an intense CC stretch at ca. $1980-2005 \mathrm{~cm}^{-1}$. This band is at an intermediate position between Ru-alkynyl complexes of the same architecture ${ }^{33,34}\left(v_{\mathrm{C}}=\mathrm{C}=2045-\right.$ $2090 \mathrm{~cm}^{-1}$ with a tendency toward lower values for more electron withdrawing alkynes) and all-carbon-substituted Ru-allenylidene complexes, where this band occurs at $1920-1950 \mathrm{~cm}^{-1} .26 \mathrm{~b}, 27$ This argument requires that in both instances the band arises from the same $\mathrm{C}^{1} \mathrm{C}^{2}$ stretching mode such that the frequency truly provides a measure for the CC bond order at this position. Despite some caveats, this is qualitatively

(26) (a) Touchard, D.; Pirio, N.; Fettouhi, M.; Ouahab, L.; Dixneuf, P. H. Organometallics 1995, 14, 5263. (b) Touchard, D.; Pirio, N.; Dixneuf, P. H. Organometallics 1995, 14, 4920. (c) Werner, H.; Stark, A.; Steinert, P.; Grünwald, C.; Wolf, J . Chem. Ber. 1995, 128, 49.

(27) Bruce, M. I. Chem. Rev. 1998, 98, 2797 and references therein.

(28) (a) Romero, A.; Peron, D.; Dixneuf, P. H. J . Chem. Soc., Chem. Commun. 1990, 1410. (b) Peron, D.; Romero, A.; Dixneuf, P. H. Gazz. Chim. Ital. 1994, 124, 497.

(29) (a) Roth, G.; Fischer, H. Organometallics 1996, 15, 1139. (b) Stein, F.; Duetsch, M.; Pohl, E.; Herbst-Irmer, R.; de Meijere, A. Organometallics 1993, 12, 2556. (c) Duetsch, M.; Stein, F.; Lackmann, R.; Pohl, E.; Herbst-Irmer, R.; de Meijere, A. Chem. Ber. 1992, 125, 2051. (d) Aumann, R.; J asper, B.; Rröhlich, R. Organometallics 1995 $14,3173$.

(30) (a) Fischer, E. O.; Heckl, B.; Werner, H. J . Organomet. Chem. 1971, 28, 359. (b) Fischer, E. O.; Leupold, M. Chem. Ber. 1972, 105, 599. (c) Boland-Lussier, B. E.; Hughes, R. P. Organometallics 1982, 1 , 635. (d) Bianchini, C.; Masi, D.; Romerosa, A.; Zanobini, F .; Peruzzini, M. Organometallics 1999, 18, 2376.

(31) Bernard, D. J .; Esteruelas, M. A.; López, A. M.; Modrego, J .; Puerta, M. C.; Valerga, P. Organometallics 1999, 18, 4995.

(32) Barluenga, J .; Aznar, F.; Gutiérrez, I.; Martín, A.; GarcíaGranda, S.; Lloraca-Baragaño, M. A. J . Am. Chem. Soc. 2000, 122, 1314.

(33) Manna, J .; J ohn, K. D.; Hopkins, M. D. Adv. Organomet. Chem. 1995, 38, 79

(34) (a) Hodge, A. J .; Ingham, S. L.; Kakkar, A. K.; Khan, M. S.; Lewis, J.; Long, N. J .; Parker, D. G.; Raithby, P. R. J. Organomet. Chem. 1995, 488, 205. (b) McDonagh, A. M.; Whittall, I. R.; Humphrey, M. G.; Skelton, B. W.; White, A. H. J . Organomet. Chem. 1996, 519, 229. (c) MCDonagh, A. M.; Cifuentes, M. P.: Whittall, I. R.; Humphrey, M. G.; Samoc, M.; Luther-Davies, B.; Hockless, D. C. R. J . Organomet. Chem. 1996, 526, 99. (d) Whittall, I. R.; Humphrey, M. G.; Houbrechts, S.; Maes, J .; Persoons, A.; Schmid, S. M.; Hockless, D. C. R. J Organomet. Chem. 1997, 544, 277. correct for the alkynyl complexes. ${ }^{33}$ Our DFT calculations (vide infra) indicate that this al so holds for aminosubstituted allenylidene complexes 4 . Within the series of the dimethylallylamine-derived complexes $\mathbf{4 a}-\mathbf{c}$ there is a clear trend to lower $v_{\mathrm{CC}}$ values as the electron richness of the ruthenium center increases (4b, 2005 $\mathrm{cm}^{-1}$; 4a, $\left.1995 \mathrm{~cm}^{-1} ; \mathbf{4 c}, 1979 \mathrm{~cm}^{-1}\right) .35$ This is in line with a higher contribution of the cumulenic resonance form with the positive charge on the metal (and hence a stronger back-bonding to the electron-accepting allenylidene ligand) as the metal center becomes increasingly electron rich. ${ }^{20 b, c}$ Further indication as to the relevance of the iminiumalkynyl type resonance form B (Chart 1) comes from the observation of an intense $\mathrm{C}=\mathrm{N}$ band near $1550 \mathrm{~cm}^{-1}$, the assignment being again supported by theory. Similar bands in the range of 1500-1600 $\mathrm{cm}^{-1}$ were reported for the 1-azoniabutadienyl complexes $\left[\mathrm{Cp}(\mathrm{CO})\left(\mathrm{Pi}^{\mathrm{i}} \mathrm{Pr}_{3}\right) \mathrm{Ru}-\mathrm{C}(=\mathrm{NRR}) \mathrm{CH}=\right.$ $\left.\mathrm{CPh}_{2}\right]^{+31}$ and, although not explicitly assigned there, for neutral aminoallenylidene complexes of chromium. ${ }^{29 b, c}$

The ${ }^{13} \mathrm{C}$ shifts for the unsaturated carbon ligands follow the usual trend $\delta\left(\mathrm{C}_{1}\right)>\delta\left(\mathrm{C}_{3}\right)>\delta\left(\mathrm{C}_{2}\right)^{13 a, c, 26-29}$ with $\delta\left(\mathrm{C}_{1}\right)=202-204 \mathrm{ppm}, \delta\left(\mathrm{C}_{3}\right)=154-157 \mathrm{ppm}$, and $\delta\left(\mathrm{C}_{2}\right)$ = 119-122 ppm for the dppm derived complexes 4a,d,f. Substitution of dppm by other diphosphine chelate ligands as in $\mathbf{4 b}, \mathbf{c}$ has hardly any influence on the remote $\beta$ - and $\gamma$-carbons but shifts $\mathrm{C}_{\alpha}$ by about $10 \mathrm{ppm}$ upfield or downfield with respect to $\mathbf{4 a}$, with the depederived complex $\mathbf{4} \mathbf{c}$ showing the signal at lowest field. The $\mathrm{NMe}_{2}$ substituents of complexes $\mathbf{4 a}-\mathbf{f}$ give rise to two different resonance signals at 40-44 ppm, separated by ca. 3 ppm for each individual compound. Likewise, in their ${ }^{1} \mathrm{H}$ NMR spectra two distinct singlets are observed for the NMe protons. F or the aliphatic depe derivative $\mathbf{4 c}$ these signals appear at 3.18 and $3.28 \mathrm{ppm}$ and are thus at rather similar field, whereas in complexes of phenyl-substituted diphosphine ligands shift differences of some $0.8 \mathrm{ppm}$ are observed for each individual representative. One of these signals is shifted to remarkably high field (2.02-2.21 ppm). We attribute this signal to the methyl group which points toward the $\mathrm{CIRu}\left(\mathrm{L}_{2}\right)_{2}$ moiety. This brings these methyl protons proximate to the center of the arene ring. At this location the field induced by the diamagnetic ring current is antiparallel to the outer field, which accounts for the stronger shielding and for the anomalous highfield shift.

Two separate signals for the $\mathrm{N}$-bound substituents point to hindered rotation around the $\mathrm{C}=\mathrm{N}$ linkage, which must consequently be attributed to some fair degree of double-bond character, consistent with the iminium alkynyl resonance form B (see Chart 1). In fact, the rotational barrier is rather substantial, as shown by dynamic NMR investigations. Even at $363 \mathrm{~K}$ in $\mathrm{CD}_{3-}$ $\mathrm{NO}_{2} \mathbf{4 a}, \mathbf{c}, \mathbf{f}$ reveal no broadening of any of these signals. From the shift differences, values of $72 \mathrm{~kJ} / \mathrm{mol}(\mathbf{4 a}, \mathbf{f})$ and $76 \mathrm{~kJ} / \mathrm{mol}$ (4c) can be derived as conservative estimates for the lower limit for $\Delta G^{*}$.

(35) The basicity differences between the all-phenyl-substituted dppm and dppe ligands largely rely on the large differences in angular strain of their chelate complexes as imposed by the ligand backbone: Szczepura, L. F.; Giambra, J .; See, R. F.; Lawson, H.; J anik, T. S.; J ircitano, A. J .; Churchill, M. R.; Takeuchi, K. J . Inorg. Chim. Acta 1995, 239, 77. 


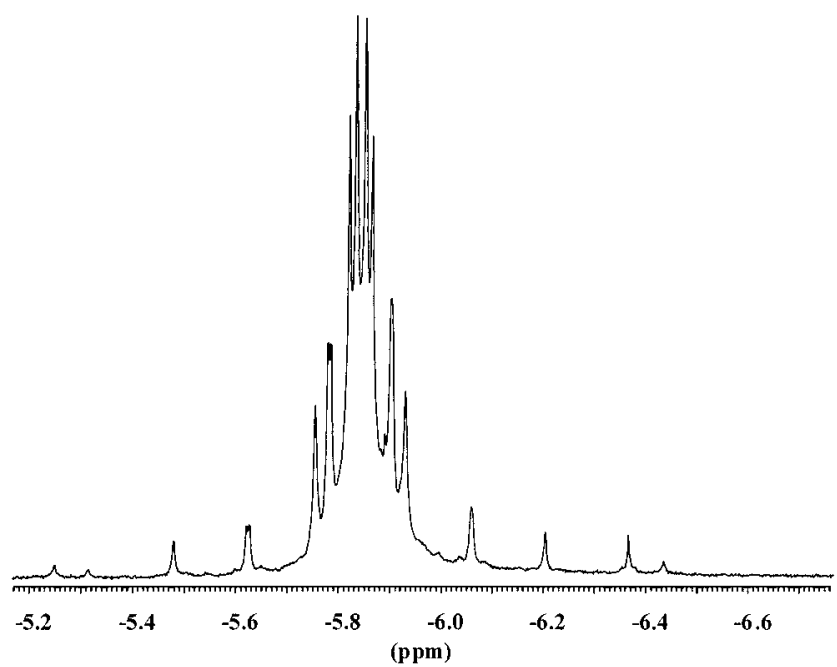

Figure 2. 31P NMR spectrum of complex $\mathbf{3 g}$.

Other ${ }^{13} \mathrm{C}$ resonances of interest include the ol efinic carbon atoms of the butenyl side chain that appear near $\delta 116 \mathrm{ppm}\left(=\mathrm{CH}_{2}\right)$ and $\delta 135 \mathrm{ppm}(=\mathrm{CH})$. The allenyl substituent of $\mathbf{4 f}$ gives rise to signals at $\delta 79.8$ and 100.0 ppm for the outer carbon atoms and $\delta 204.3$ ppm for the internal carbon atoms. The ${ }^{31 P}$ NMR spectra of complexes $\mathbf{4 e}$ and $\mathbf{3 g}$ are remarkable in that $\mathrm{AA}^{\prime} \mathrm{BB}^{\prime}$ multiplets are observed instead of a singlet normally associated with this architecture (Figure 2). This can be traced to the presence of a chirality center residing on either the allylic carbon of the butenyl side chain (4e) or the quaternary nitrogen $(\mathbf{3 g})$.

The UV/vis spectra display, besides the $n / \pi^{*}$ and $\pi / \pi^{*}$ transitions of the phosphine ligands, four different transitions: one broad band of rather low absorptivity ( $\log \epsilon<3$ ) at $620-690 \mathrm{~nm}$, one shoulder at 435-465 $\mathrm{nm}$ with $\log \epsilon \approx 3$, one very intense absorption ( $\log \epsilon>$ 4) at ca. $400 \mathrm{~nm}$, and another moderately intense band at ca. $265 \mathrm{~nm}$, superimposed as a shoulder onto the even more intense phenyl phosphine-based transitions in the case of the dppm- and dppe-derived complexes but clearly visible as an isolated band at $287 \mathrm{~nm}(\log \epsilon=$ 3.06) for the depe derivative $\mathbf{4 C}$ (Figure 3). Comparison of the band positions in $\mathrm{CH}_{2} \mathrm{Cl}_{2}$ and $\mathrm{CH}_{3} \mathrm{CN}$ reveals negative solvatochromism for the main absoption band with $\Delta v$ ranging from 600 to $710 \mathrm{~cm}^{-1}$, indicating a decrease in polarity upon electronic excitation. There is again a marked influence of the metal center on the band positions, mainly on the two low-energy bands which are associated with the symmetry-forbidden $\mathrm{HOMO/LUMO}$ transition and the symmetry-allowed excitation from the second highest occupied level (SHO$\mathrm{MO})$, as will be detailed in a later section. The HOMO/ LUMO and the SHOMO/LUMO transition energies steadily decrease within the series $\mathbf{4 b}>\mathbf{4 a}>\mathbf{4 c}$ from 16000 to 14500 and from 25700 to $25000 \mathrm{~cm}^{-1}$. This mirrors the trend in ${ }^{13} \mathrm{C}$ NMR shifts for the carbon atom $\mathrm{C}_{\alpha}$. It is generally agreed that the characteristic lowfield shifts of carbene, vinylidene, and allenylidene carbon atoms arise from the paramagnetic term which, inter alia, depends on the energy gap between occupied and unoccupied levels to which the carbon atom in question contributes. ${ }^{36}$ The lower the energy gap, the 2016.

(36) Czech, P. T.; Ye, X.-Q.; Fenske, R. F. Organometallics 1990, 9 , more downfield the resonance signal. For a series of compounds so closely related as $\mathbf{4 a}-\mathbf{c}$, one may reasonably expect other factors such as the p-orbital contributions to both levels and the symmetry properties of the transitions in question to be constant such that the energy gap becomes the determining factor.

Crystallography. The molecular structure of complex $4 a$ has been communicated in our previous report. ${ }^{13 a}$ We have also characterized the dppe anal ogue $\mathbf{4 b}$, which crystallizes as a tris(dichloromethane) solvate. Figure 4 gives a graphical representation of the cation. Selected bond distances and angles of the cationic aminoallenylidene complexes $\mathbf{4 a}, \mathbf{b}$ are provided in Table $\mathbf{1}$, while all information pertinent to data collection and refinement for $\mathbf{4} \mathbf{b}$ are collected in Table 2. Apart from the widely differing cisoid $\mathrm{P}-\mathrm{Ru}-\mathrm{P}$ angles due to the constraints imposed by the chelate ligand backbone, the cation structures are very similar. The whole $\mathrm{CIRuC}_{3-}$ $\left(\mathrm{CH}_{3}\right) \mathrm{N}$ entity is essentially coplanar (maxmium deviation $0.096 \AA$ for C 3 ) and almost perpendicular to the best plane $\mathrm{RuP}_{4}$ (interplanar angle $89.3^{\circ}$ ). The $\mathrm{RuC}_{3}$ axis is nearly linear for both cations $(\mathbf{4 a}, \mathbf{b}$ : $\mathrm{Ru}-\mathrm{C} 1-\mathrm{C} 2=$ $\left.175.3(4), 177.8(7)^{\circ} ; \mathrm{C} 1-\mathrm{C} 2-\mathrm{C} 3=175.1(6), 168.7(9)^{\circ}\right)$, with some higher degree of bending at $\mathrm{C} 2$.

From a structural viewpoint one may reasonably expect that a higher contribution of the alkynyl type resonance form should lead to shorter $\mathrm{C} 1-\mathrm{C} 2$ but longer $\mathrm{Ru}-\mathrm{C} 1$ and $\mathrm{C} 2-\mathrm{C} 3$ bond lengths as compared to the cumulenic structure. $\mathbf{4 a , b}$ may therefore be compared with Ru(II)-alkynyl complexes on one hand and allcarbon-substituted allenylidene complexes, which better, but still not perfectly, resemble the genuine cumuIenic structure ${ }^{26}$ on the other. In fact, there is a substantial bond length alternation along the $\mathrm{RuC}_{3} \mathrm{~N}$ chain. The Ru-C1 bond lengths in $\mathbf{4 a , b}$ (1.950(4) and 1.934(8) $\AA$ ) are considerably shorter than those in ruthenium al kynyl complexes (1.994-2.078 $\AA$ ), 27,33,37 a notable exception being trans- $\mathrm{Cl}(\mathrm{dppm})_{2} \mathrm{RuCCH}$, for which a short Ru-C bond of 1.906(9) $\AA$ and a short $C \equiv$ $C$ bond of 1.162(9) $\AA$ have been reported. ${ }^{38}$ They are, however, longer than those in all-carbon-substituted allenylidene complexes of the same or closely related ruthenium(II) fragments $(1.85-1.886 \AA) .{ }^{27}$ The same trend holds for the $\mathrm{C} 1-\mathrm{C} 2$ interatomic distances. The observed values of 1.218(6) $\AA$ in $\mathbf{4 a}$ and $1.203 \AA$ in $\mathbf{4 b}$ are only slightly long with respect to the $C \equiv C$ triple bond in purely organic compounds ( $1.189 \AA$ for the $C \equiv$ $\mathrm{C}$ bond in alkynes, where the sp carbon is conjugated with $\mathrm{sp}^{2}$ carbon atoms) ${ }^{39}$ or those in complexes of $\sigma$-bonded alkynyl ligands, for which an average value of $1.201 \AA$ has been determined for a broad range of

(37) (a) Field, L. D.; George, A. V.; Hockless, D. C. R.; Purches, G. R.; White, A. H. J . Chem. Soc., Dalton Trans. 1996, 2011. (b) Hodge A. J .; Ingham, S. L.; Kakkar, A. K.; Khan, M. S.; Lewis, J .; Long, N. J .; Parker, D. G.; Raithby, P. R. J . Organomet. Chem. 1995, 488, 205. (c) McDonagh, A. M.; Whittall, I. R.; Humphrey, M. G.; Skelton, B. W.; White, A. H.J . Organomet. Chem. 1996, 519, 229. (d) McDonagh, A. M.; Whittall, I. R.; Humphrey, M. G.; Hockless, D. C. R.; Skelton, B. W.; White, A. H. J . Organomet. Chem. 1996, 523, 33. (e) McDonagh, A. M.; Cifuentes, M. P.; Whittall, I. R.; Humphrey, M. G.; Samoc, M.; Luther-Davies, B. J . Organomet. Chem. 1996, 526, 99. (f) Zhu, Y. Millet, D. B.; Wolf, M. O.; Rettig, S. J . Organometallics 1999, 18, 1930. (g) McDonagh, A. M.; Lucas, N. T.; Cifuentes, M. P.; Humphrey, M. G.; Houbrechts, S.; Persoons, A. J . Organomet. Chem. 2000, 605, 193.

(38) Haquette, P.; Pirio, N.; Touchard, D.; Toupet, L.; Dixneuf, P. H. J. Chem. Soc., Chem. Commun. 1993, 163.

(39) Lide, D. R.; Frederikse, H. P. R. CRC Handbook of Chemistry and Physics, 76th ed.; CRC Press: Boca Raton, FL, 1995. 


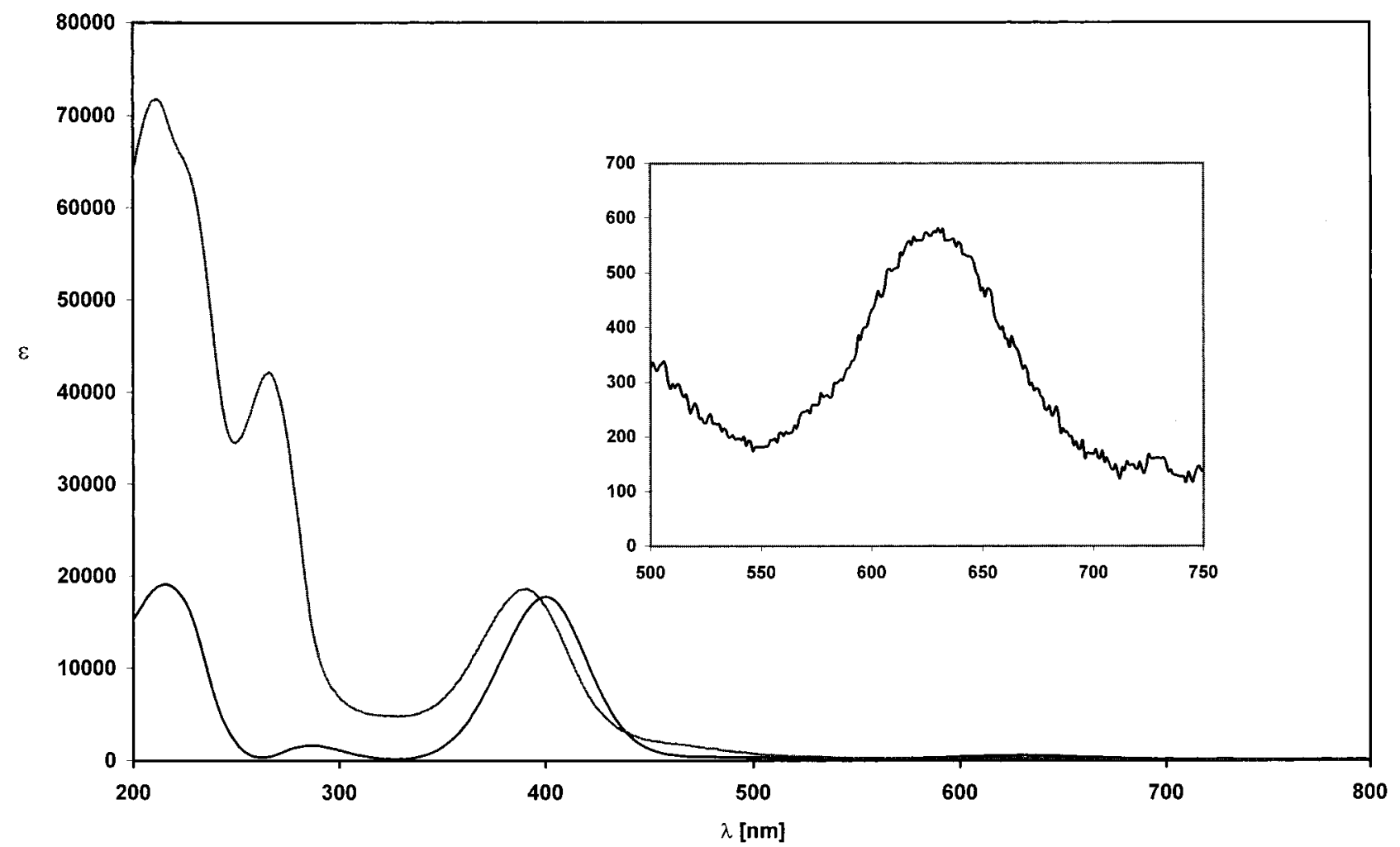

Figure 3. UV/vis spectra of aminoallenylidene complexes $\mathbf{4 c , d}$ in $\mathrm{CH}_{3} \mathrm{CN}$. Insert: $500-750 \mathrm{~nm}$ region for complex $\mathbf{4 c}$ magnified.

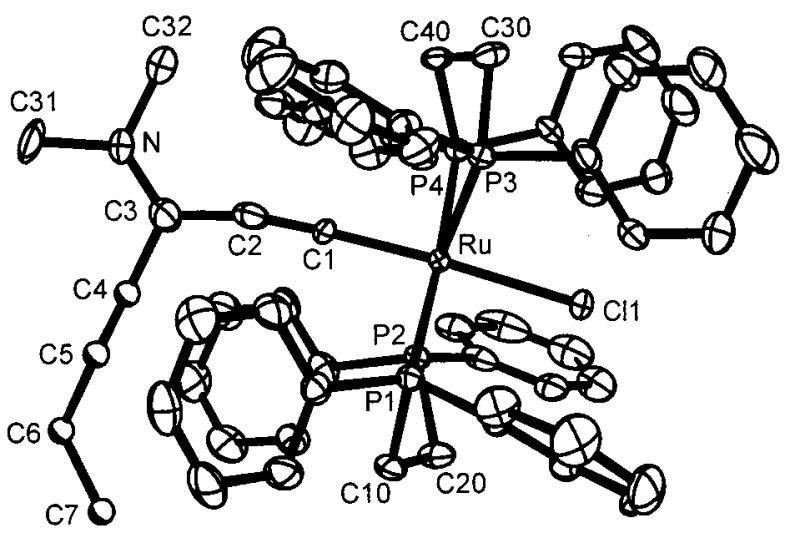

Figure 4. Plot of the cation trans-[Cl(dppe $)_{2} \mathrm{RuCCC}$ $\left.\left(\mathrm{NMe}_{2}\right)\left(\mathrm{C}_{4} \mathrm{H}_{7}\right)\right]^{+}$of complex $\mathbf{4 b}$ with the atomic labeling scheme of the more important atoms.

transition metals. ${ }^{33}$ In neutral mono- or bis(alkynyl) complexes of the trans- $X R u\left(L_{2}\right)_{2}$ fragment, values are typically in the range of 1.190-1.226 $\AA$ (average value $1.203 \AA) .{ }^{37}$ In cationic all-carbon-substituted allenylidene complexes $[\{\mathrm{Ru}\}=\mathrm{C}=\mathrm{C}=\mathrm{CRR}]^{+}$there seems to be a tendency toward longer CC bonds (1.218(6)1.29(3) $\AA$, average $1.259 \AA$ ). ${ }^{27}$ The C2 $-\mathrm{C} 3$ bond lengths of 1.372(9) $\AA$ (4a) and 1.393(13) $\AA$ (4b) are roughly midway between those for a single bond between an spand an sp ${ }^{2}$-hybridized carbon atom (1.431 $\AA$ ) and a $\mathrm{C}=$ $C$ double bond in allenes $(1.307 \AA)^{39}$ but fall within the range observed for all-carbon-substituted allenylidene complexes of the same metal fragments (1.329-1.42 $\AA$ ). ${ }^{27}$ The most revealing part of the structure is, however, the immediate surroundings of the nitrogen atom. Thus, the $\mathrm{N}-\mathrm{C} 3$ bond lengths in $\mathbf{4 a}, \mathbf{b}$ are much shorter than the N-methyl bonds (1.313(13) $\AA$ vs 1.460(11) and 1.466(13) $\AA$ in $\mathbf{4 b}$; comparable bonds in $\mathbf{4 a}$ may
Table 1. Selected Bond Lengths $(\AA)$ and Angles (deg) for $\left[\mathrm{Cl}\left(\mathrm{L}_{2}\right)_{2} \mathrm{RuCCC}\left(\mathrm{NMe}_{2}\right) \mathrm{C}_{4} \mathrm{H}_{7}\right]^{+} \mathrm{EF}_{6} \mathrm{C}^{-}\left(\mathrm{L}_{2}=\right.$ dppm, $\left.E=P, 4 a ; L_{2}=d p p e, E=S b, 4 b\right)$

\begin{tabular}{|c|c|c|}
\hline & $4 a$ & 4b \\
\hline $\begin{array}{l}\mathrm{Ru}-\mathrm{Cl} 1 \\
\mathrm{Ru}-\mathrm{P} 1 \\
\mathrm{Ru}-\mathrm{P} 2 \\
\mathrm{Ru}-\mathrm{P} 3 \\
\mathrm{Ru}-\mathrm{P} 4 \\
\mathrm{Ru}-\mathrm{C} 1 \\
\mathrm{C} 1-\mathrm{C} 2 \\
\mathrm{C} 2-\mathrm{C} 3 \\
\mathrm{~N}-\mathrm{C} 3 \\
\mathrm{C} 31-\mathrm{N} \\
\mathrm{C} 32-\mathrm{N} \\
\mathrm{C} 3-\mathrm{C} 4 \\
\mathrm{C} 4-\mathrm{C} 5 \\
\mathrm{C} 5-\mathrm{C} 6 \\
\mathrm{C} 6-\mathrm{C} 7\end{array}$ & $\begin{array}{c}\text { Bond Lengths a } \\
2.4686(10) \\
2.3651(11) \\
2.3733(11) \\
2.3521(11) \\
2.3570(11) \\
1.950(4) \\
1.218(6) \\
1.372(9) \\
1.244(8) \\
1.505(7) \\
1.495(6) \\
1.499(7) \\
1.470(8) \\
1.499(9) \\
1.317(9)\end{array}$ & $\begin{array}{l}2.457(2) \\
2.394(2) \\
2.392(2) \\
2.411(2) \\
2.396(2) \\
1.934(8) \\
1.232(13) \\
1.393(13) \\
1.320(13) \\
1.460(11) \\
1.466(13) \\
1.48(2) \\
1.52(4) \\
1.56(4) \\
1.34(5)\end{array}$ \\
\hline $\begin{array}{l}\text { P1-Ru-P2 } \\
\text { P3-Ru-P4 } \\
\text { P3-Ru-P1 } \\
\text { P4-Ru-P2 } \\
\text { C1-Ru-Cl1 } \\
\text { C2-C1-Ru } \\
\text { C1-C2-C3 } \\
\text { C2-C3-N }\end{array}$ & $\begin{array}{c}\text { Bond Angles (deg) } \\
70.73(4) \\
71.62(4) \\
108.21(4) \\
109.88(4) \\
175.21(12) \\
175.3(4) \\
175.1(6) \\
126.6(7)\end{array}$ & $\begin{array}{l}83.02(7) \\
82.67(8) \\
97.82(6) \\
96.92(6) \\
176.8(2) \\
177.8(7) \\
168.7(9) \\
123.1(8)\end{array}$ \\
\hline
\end{tabular}

a For the disordered atoms C3, N, C31, C4-C7 (4a) and C4C7 (4b) only the major orientation is given.

beartificially short and long due to disorder of the whole C3-N-C10,C11 butenyl entity). Moreover, the angle sum at nitrogen is exactly $360^{\circ}$, such that the nitrogen clearly has iminium character. This feature seems to be general for all structurally characterized aminoallenylidene complexes irrespective of the exact nature of the metal fragment. $12 \mathrm{~b}, 13 \mathrm{a}, 29 \mathrm{~b}, \mathrm{~d}, 40$

In conclusion, structural and spectroscopic data for aminoallenylidene complexes $\mathbf{4}$ agree well in placing 
Table 2. Crystallographic Data for Complex 4b

\begin{tabular}{ll}
\hline formula & $\mathrm{C}_{61} \mathrm{H}_{61} \mathrm{ClF}_{6} \mathrm{NP}_{4} \mathrm{RuSb} \cdot 3 \mathrm{CH}_{2} \mathrm{Cl}_{2}$ \\
fw & 1559.04 \\
temp & $173(2) \mathrm{K}$ \\
wavel ength & $0.71073 \AA$ \\
cryst syst & monoclinic \\
space group & $\mathrm{Ia}$ \\
$\mathrm{a}$ & $19.162(2) \AA$ \\
$\mathrm{b}$ & $16.458(2) \AA$ \\
$\mathrm{C}$ & $22.685(4) \AA$ \\
$\beta$ & $112.51(8)^{\circ}$ \\
$\mathrm{V}$ & $6608.9(2) \AA^{3}$ \\
$\mathrm{Z}$ & 4 \\
density (calcd) & $1.567 \mathrm{Mg} / \mathrm{m}^{3}$ \\
absorption coeff & $1.074 \mathrm{~mm} \mathrm{~m}^{-1}$ \\
$\mathrm{~F}(000)$ & 3144 \\
cryst size & $0.3 \times 0.25 \times 0.15 \mathrm{~mm}$ \\
$\theta$ range for data collection & $1.57-27.51^{\circ}$ \\
index ranges for data collection & $-22 \leq \mathrm{h} \leq 24,-13 \leq \mathrm{k} \leq 21$, \\
& $-24 \leq \mathrm{I} \leq 29$ \\
no. of rflns msd & 8046 \\
no. of indep rflns & $7775(\mathrm{R}(\mathrm{int})=0.0518)$ \\
refinement method & full-matrix least squares on $\mathrm{F}^{2}$ \\
no. of data/restraints/params & $7775 / 11 / 757$ \\
goodness of fit on $\mathrm{F}^{2}$ & 1.056 \\
final $\mathrm{R}$ indices $(\mathrm{I}>$ 4 $\sigma(\mathrm{I}))$ & $\mathrm{R} 1=0.0505, \mathrm{wR} 2=0.1332$ \\
$\mathrm{R}$ indices (all data) & $\mathrm{R} 1=0.0619$, wR2 $=0.1414$ \\
absolute structure param & $0.62(4)$ \\
largest diff peak and hole & 1.59 and $-1.04 \mathrm{e} / \AA^{3}$ \\
&
\end{tabular}

Table 3. Electrochemistry Data for Complexes $4 a-f$ and $3 f, g$

\begin{tabular}{|c|c|c|c|c|}
\hline compd & solvent & $\begin{array}{c}E_{1 / 2}(O x) \\
(V)\end{array}$ & $\begin{array}{c}E_{1 / 2}(\text { red }) \\
(V)\end{array}$ & $\begin{array}{l}\mathrm{E}_{\text {follow }} \\
(\mathrm{V})\end{array}$ \\
\hline $4 a$ & $\begin{array}{l}\mathrm{CH}_{2} \mathrm{Cl}_{2} \\
\mathrm{THF}\end{array}$ & $\begin{array}{l}+0.57 \\
+0.50\end{array}$ & $\begin{array}{l}-2.14^{\mathrm{a}, \mathrm{b}, \mathrm{e}} \\
-2.155^{\mathrm{b}, \mathrm{e}}\end{array}$ & $-1.38^{d}-1.00^{d}$ \\
\hline $4 b$ & $\mathrm{CH}_{2} \mathrm{Cl}_{2}$ & +0.665 & $-2.11^{\mathrm{a}, \mathrm{b}, \mathrm{e}}$ & $-1425-110 d$ \\
\hline $4 c$ & $\begin{array}{l}\mathrm{CH}_{2} \mathrm{Cl}_{2} \\
\mathrm{THF}\end{array}$ & $\begin{array}{l}+0.425 \\
+0.325\end{array}$ & $\begin{array}{l}<-2.20 \\
-2.16^{\mathrm{b}, \mathrm{e}}\end{array}$ & \\
\hline 4d & $\begin{array}{l}\mathrm{CH}_{2} \mathrm{Cl}_{2} \\
\mathrm{CH}_{3} \mathrm{CN}\end{array}$ & $\begin{array}{l}+0.60^{c} \\
+0.595\end{array}$ & $\begin{array}{l}-2.17^{\mathrm{a}, \mathrm{b}, \mathrm{e}} \\
-2.09^{\mathrm{a}, \mathrm{b}, \mathrm{e}}\end{array}$ & $\begin{array}{l}-1.45^{d}+0.40 \\
-1.375^{d}\end{array}$ \\
\hline $4 e$ & $\mathrm{CH}_{2} \mathrm{Cl}_{2}$ & $+0.645^{\mathrm{a}, \mathrm{e}}$ & $-2.11^{\mathrm{a}, \mathrm{e}}$ & \\
\hline $4 f$ & $\begin{array}{l}\mathrm{CH}_{2} \mathrm{Cl}_{2} \\
\mathrm{THF}\end{array}$ & $\begin{array}{l}+0.57 \\
+0.57\end{array}$ & $\begin{array}{l}-2.18^{\mathrm{a}, \mathrm{b}, \mathrm{e}} \\
-2.08^{\mathrm{a}, \mathrm{b}, \mathrm{e}}\end{array}$ & $-1.47,{ }^{\mathrm{d}}-1.04,^{\mathrm{d}}+0$ \\
\hline $3 f$ & $\begin{array}{l}\mathrm{CH}_{2} \mathrm{Cl}_{2} \\
\mathrm{CH}_{3} \mathrm{CN}\end{array}$ & $\begin{array}{l}+0.365^{c} \\
+0.375^{c}\end{array}$ & $\begin{array}{l}\text { ndg } \\
\text { nd }\end{array}$ & \\
\hline 3g & $\begin{array}{l}\mathrm{CH}_{2} \mathrm{Cl}_{2} \\
\mathrm{THF}\end{array}$ & $\begin{array}{l}+0.33^{e} \\
+0.28^{e}\end{array}$ & $\begin{array}{l}\text { nd } \\
-2.67^{d},-2.90^{d}\end{array}$ & $\begin{array}{l}-0.43^{\mathrm{d}} \\
-1.44, \mathrm{~d}, \mathrm{f}-0.79, \mathrm{~d} \\
\quad+0.23, \mathrm{~d}+0.55\end{array}$ \\
\hline
\end{tabular}

${ }^{a} E_{1 / 2}$ determined at $195 \mathrm{~K} .{ }^{b}$ At $298 \mathrm{~K}$; irreversible $2 \mathrm{e}^{-}$process. c Quasireversible. ${ }^{d}$ Peak potentials of irrversible processes determined at $\mathrm{v}=0.2 \mathrm{~V} / \mathrm{s}$. ${ }^{\mathrm{e}}$ Only partially reversible. ${ }^{f}$ Cathodic peak following oxidation. ${ }^{9} \mathrm{nd}=$ not determined.

them at an intermediate position between "true" allenylidene and 1-azoniabutenynyl complexes with major contributions of the latter resonance form.

Electrochemistry. We have previously reported on the electrochemical behavior of ammoniobutenynyl complexes of type 3. ${ }^{13 \mathrm{~d}} \mathrm{~A}$ combination of cyclic and squarewave voltammetry revealed partially to fully reversible one-electron oxidation to Ru(III) species and irreversible reductions occurring as two closely spaced waves. The reduction processes are accompanied by loss of the free amine, as was inferred from the distinct changes in the anodic response after scanning past the cathodic waves, identical with those imparted by the presence of the free amine. 3f,g behave identically and present no new features. Relevant data are collected in Table 3. Halfwave potentials are reported relative to the internal ferrocene/ferrocenium standard throughout.

(40) Fischer, E. O.; Kalder, H. J .; Frank, A.; Köhler, H.; Huttner, G. Angew. Chem. 1976, 88, 683; Angew. Chem., Int. Ed. Engl. 1976, $15,623$.
The electrochemical responses of aminoallenylidene complexes $\mathbf{4 a -} \mathbf{- g}$ are all rather similar, irrespective of the substituents on the iminium nitrogen or the solvent used in the experiment. Each complex displays a chemically reversible one-electron oxidation, as ascertained by a peak current ratio $i_{p, r e v} / i_{p, f o r w}$ of exactly or close to unity. In several instances the oxidation waves show the signatures of somewhat sluggish electron transfer kinetics, as is occasionally observed for $\mathrm{Ru}(\mathrm{II} / \mathrm{III})$ couples in organometallic environments. ${ }^{13 d, 41,42}$ Diagnostic values such as the peak-widths at half-height for the forward peak or the peak-to-peak separations progressively exceed those measured for the internal Nernstian ferrocene/ferrocenium standard when the sweep rate is increased or the temperature is lowered. ${ }^{43} \mathrm{~F}$ or the dppm-derived complexes $\mathbf{4 a}, \mathbf{d}, \mathbf{f}$ the oxidation potential lies in a rather narrow region between +0.57 and +0.60 $\mathrm{V}$. The only exception is complex $\mathbf{4 e}$, featuring a dangling amino group within the side chain. This species not only calls for higher sweep rates in order to suppress chemical decomposition following electron transfer but also exhibits a somewhat higher $E_{1 / 2}$ value of $+0.645 \mathrm{~V}$. The oxidation potentials are consistently more anodic than those for ammoniobutenynyl complexes 3, which are usually in the range of +0.33 to $+0.36 \mathrm{~V}$ in $\mathrm{CH}_{2} \mathrm{Cl}_{2}$ solution. $13 \mathrm{~d}$ The isomeric couple $3 \mathrm{ff} /$ 4f clearly illustrates this point: $\mathbf{3 f}$ is more easily oxidized by some $200 \mathrm{mV}$ than its rearranged counterpart. This difference is attributed to the positive charge in resonance or even residing on the metal center in complexes 4, while it is further removed from the metal center in ammoniobutenynyl complexes 3 . Such reasoning requires that the oxidation directly involves the metal center. We will later address this issue from a theoretical viewpoint.

All complexes 4 also undergo a single reduction process which shows, however, some peculiarity: at 298 $\mathrm{K}$ and low sweep rates $\mathrm{v}$ this process is chemically irreversible and its peak currents are approximately twice as high as that of the oxidation wave (Figure 5a). As the sweep rate is increased and/or the temperature lowered, the following chemical reaction is gradually suppressed such that the reverse peak for the reoxidation is observed. This allows for the evaluation of thermodynamically meaningful $E_{1 / 2}$ values for the reduction process (Figure $5 b),{ }^{44}$ although full chemical reversibility can rarely be achieved. As the reversibility increases, the forward peak current for the reduction wave more and more resembles that of the oxidation. Similar results were obtained from the $i$ vs $t^{-1 / 2}$ or $i$ vs $\mathrm{t}^{1 / 2}$ plots in chronoamperometry or chronocoulometry measurements on some individuals. ${ }^{45} \mathrm{All}$ this points to the el ectrochemically induced chemical degradation of the reduced species producing other el ectroactive species that are further reduced by one electron at the reduction potential of the parent complex. Indeed, several new features are observed upon scan reversal following reduction. While the absolute response depends on the nature of the solvent (see Table 3 for details), more

(41) Winter, R. F.; Scheiring, T. Z. Anorg. Allg. Chem. 2000, 626, 1196.

(42) al Dulaimi, J . P.; Clark, R. J . H.; Saavedra, M. S.; Salam, M. A. Inorg. Chim. Acta 2000, 300-302, 175.

(43) Nicholson, R. S. Anal. Chem. 1965, 37, 1351.

(44) Nicholson, R. S.; Shain, I. Anal. Chem. 1964, 37, 706. 

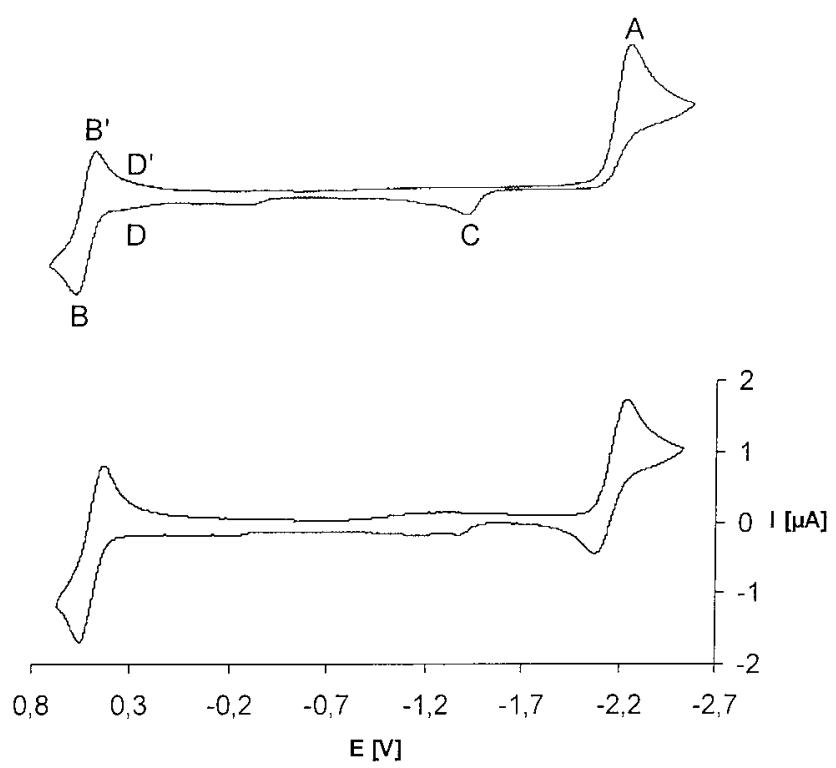

Figure 5. Cyclic voltammograms of complex $\mathbf{4 a}$ in THF solvent at (a, top) $298 \mathrm{~K}$ and $\mathrm{v}=0.2 \mathrm{~V} / \mathrm{s}$ and (b, bottom) $195 \mathrm{~K}$ and $\mathrm{v}=0.1 \mathrm{~V} / \mathrm{s}$.

common features include an irreversible anodic peak at ca. -1.37 to $-1.45 \mathrm{~V}$ (peak $\mathrm{C}$ in Figure $5 \mathrm{~b}$ ) and a more or less reversible couple at ca. +0.32 to $+0.40 \mathrm{~V}$ : i.e., sligthly cathodic of the oxidation wave (peaks D and D'). Since the species responsible for this wave are only generated when the reduction is performed first and much of this species is lost by diffusion into the bulk of solution during the reverse scan (note that the potential difference between this feature and the reduction potential exceeds $2 \mathrm{~V}$ ), the peak heights are very small. Therefore, peaks $D$ and $D^{\prime}$ appear only as shoulders superimposed on the original oxidation wave, peaks $B$ and $B^{\prime}$. All waves of electrogenerated species gradually disappear as the reduction becomes more reversible.

Electrochemical half-wave potentials provide an even more direct measure for the electron density on the metal fragment, providing the actual redox process deeply involves the metal. Our data point in this direction: as the electron donation of the diphosphine ligands increases, the $E_{1 / 2}$ values of both the oxidation and the reduction processes experience a cathodic shift. From our admittedly limited data set the effect on the oxidation potential seems to exceed that on the reduction, and this may reflect a higher metal contribution to the HOMO as compared to the LUMO. This is indeed found in our calculations (vide infra).

Spectroelectrochemistry. With their characteristic $\mathrm{C} \equiv \mathrm{C}$ and $\mathrm{C}=\mathrm{N}$ IR bands and their charge-transfer absorption in the visible region aminoallenylidene com-

(45) In chronoamperometry, the diffusional current is given by the Cottrell equation $i=n F A D^{1 / 2} c /(\pi t)^{1 / 2}, n$ being the number of electrons involved, A the active electrode area, F the Faraday constant, D the diffusion constant of the analyte, and c the analyte concentration. Plots of $i$ vs $t^{-1 / 2}$ give a straight line. From its slope $D$ can be determined once $n$ is known. For 4 e, $D$ values of $0.62 \times 10^{-5}$ and $0.14 \times 10^{-5} \mathrm{~cm}^{2}$ $\mathrm{s}^{-1}$ were determined in $0.25 \mathrm{mM} \mathrm{NBu}_{4} \mathrm{PF}_{6}$ in $\mathrm{CH}_{2} \mathrm{Cl}_{2}$ at 298 and 215 $\mathrm{K}$, respectively, on the basis of the oxidation. If the analyte undergoes two different electron-transfer processes, the ratio of the slopes equals the ratio of electrons transferred in these steps, provided the measure ments are performed under identical experimental conditions. See also: Bard, A. J .; Faulkner, L. R. Electrochemical Methods: Fundamentals and Applications; Wiley: New York, 1980; Chapter 5.9. plexes trans- $\left[\mathrm{Cl}\left(\mathrm{L}_{2}\right)_{2} \mathrm{RuCCC}\left(\mathrm{NR}_{2}\right) \mathrm{R}^{\prime}\right]^{+}$(4) possess highly intense spectroscopic labels that are sensitive toward the spin and charge distribution within the molecule. Since most representatives are reversibly oxidized to their respective dications, combining electrochemistry with various spectroscopic techniques should allow us to probe for the effect of electron transfer upon the bonding and the structure. We were able to record the UV/vis and IR spectra of the oxidized dications for complexes $\mathbf{4 a}, \mathbf{c}, \mathbf{d}, \mathbf{f}$ and the EPR spectra of the oxidized forms of complexes $\mathbf{4 a , d}$ generated directly in the EPR tube. The results of the UV/Vis and IR spectroelectrochemical experiments are summarized in Table 4. In each case we checked for chemical reversibility by rereducing the oxidized forms to the parent compounds. In general, the optical yield of the starting material was higher than $85 \%$ for optical and higher than $75 \%$ for the IR methods, the differences being due to the higher concentrations (and the concomitant longer el ectrolysis times) required in IR spectroscopy. In every case re reduced samples displayed in the spectral region of interest no features other than those of the parent material, such that we feel confident that the traces obtained after exhaustive oxidation really originate from the oxidized species.

Figure 6 documents the changes in the optical spectra during the oxidation of compounds $\mathbf{4 c}$, $\mathbf{d}$. Most striking is a blue shift of the prominent absorption band by about $4300 \mathrm{~cm}^{-1}$ upon oxidation. A plausible explanation is the preferential lowering of the occupied level (which in this instance is the second highest occupied molecular orbital (SHOMO), as will be discussed later) with respect to the LUMO upon oxidation, provided that the origin of this band remains unaffected by the electrontransfer process. The similar extinction coefficients in both oxidation states agree favorably with this assumption. We have already reported a shift of identical magnitude of this band during the second oxidation of the aminoallenylidene complex trans-[Cl(dppm) ${ }_{2} \mathrm{RuCCC}$ $\left(\mathrm{NMe}_{2} \mathrm{C}_{2} \mathrm{H}_{4} \mathrm{~F} \mathrm{C}\right]^{+}$, where the appended ferrocenyl moiety $(\mathrm{Fc})$ is oxidized first. ${ }^{13 \mathrm{~b}}$ The HOMO/LUMO band located at $630-650 \mathrm{~nm}$ also shifts during oxidation and is then observed as a much stronger band at ca. $2000 \mathrm{~cm}^{-1}$ lower energy. Again, this has precedent in the ferrrocenyl ethyl-substituted anal ogue. ${ }^{13 b}$ This new band was tentatively assigned to a $d-d$ transition within the $d^{5}$ configuration of $\mathrm{Ru}(\mathrm{III})$ but, in light of our theoretical results (vide infra), involves the metal and the unsaturated ligand and displays considerable charge-transfer characteristics.

In IR spectroelectrochemistry the highly intense allenylidene stretch bleaches during oxidation and is replaced by a new band at $1950-1920 \mathrm{~cm}^{-1}$, as shown for the allylpiperidine-derived complex $\mathbf{4 d}$ in Figure 7. This feature is so weak that high concentrations up to the upper detection limit of the IR spectrometer are mandatory in order to observe it. We wish to emphasize again that the largely reduced absorptivity of this feature is an intrinsic property of our systems and is not due to extensive decomposition, as ascertained by back-electrolysis. In contrast to the $\mathrm{C} \equiv \mathrm{C}$ stretch, the $\mathrm{C}=\mathrm{N}$ band retains its absorptivity while also being shifted upon oxidation. The direction of this shift is, however, not uniform. A lowering of the $\mathrm{C}=\mathrm{N}$ frequen- 
Table 4. Spectroelectrochemical Results on Complexes 4

\begin{tabular}{|c|c|c|c|c|c|}
\hline \multirow[b]{2}{*}{ compd } & \multirow[b]{2}{*}{ solvent ${ }^{a}$} & \multicolumn{2}{|c|}{ prior to oxidn } & \multicolumn{2}{|c|}{ after oxidn ${ }^{b}$} \\
\hline & & $\lambda_{\max }(\mathrm{nm})\left(\epsilon\left(\mathrm{mol}^{-1} \mathrm{~cm}^{-1}\right)\right)$ & $v\left(\mathrm{~cm}^{-1}\right)$ & $\lambda_{\max }(\mathrm{nm})\left(\epsilon\left(\mathrm{mol}^{-1} \mathrm{~cm}^{-1}\right)\right)$ & $v\left(\mathrm{~cm}^{-1}\right)$ \\
\hline $4 a$ & DCE & $\begin{array}{l}640 \text { (310) } \\
396 \text { (16 800) }\end{array}$ & $\begin{array}{l}1995 \text { (vs, CC) } \\
1572(\mathrm{~s}, \mathrm{CN})\end{array}$ & $\begin{array}{l}567(940) \\
402(\mathrm{sh})(4300) \\
338(16800)\end{array}$ & $\begin{array}{l}1948(w, C C) \\
1554(s, C N)\end{array}$ \\
\hline 4c & $\mathrm{CH}_{3} \mathrm{CN}$ & $\begin{array}{l}630(380) \\
400(17400) \\
287(1150)\end{array}$ & $\begin{array}{l}1979 \text { (vs, CC) } \\
1564(\mathrm{~s}, \mathrm{CN})\end{array}$ & $\begin{array}{l}557(1020) \\
396(\text { sh, 6300) } \\
341(12700) \\
284(6100)\end{array}$ & $\begin{array}{l}n^{c} \mathrm{c} \\
1532(\mathrm{~s}, \mathrm{CN})\end{array}$ \\
\hline $\mathbf{4 d}$ & DCE & $\begin{array}{l}654(150) \\
395(21500) \\
268 \text { (49 000) }\end{array}$ & $\begin{array}{l}1990 \text { (vs, CC) } \\
1547 \text { (s, CN) }\end{array}$ & $\begin{array}{l}567(1400) \\
339(10850) \\
288(25600) \\
277(24500)\end{array}$ & $\begin{array}{l}1942(\mathrm{w}, \mathrm{CC}) \\
1590(\mathrm{~s}, \mathrm{CN})\end{array}$ \\
\hline $4 f$ & DCE & $\begin{array}{l}628(630) \\
400(11800) \\
264(32500)\end{array}$ & $\begin{array}{l}1997 \text { (vs, CC) } \\
1927 \text { (m, CC) } \\
1573(\mathrm{~s}, \mathrm{CN})\end{array}$ & $\begin{array}{l}571(1500) \\
403(\mathrm{sh})(5100) \\
340(9150)\end{array}$ & $\begin{array}{l}1919(\mathrm{vw}, \mathrm{CC}) \\
1545(\mathrm{~s}, \mathrm{CN})\end{array}$ \\
\hline
\end{tabular}

${ }^{a} \mathrm{DCE}=1,2-\mathrm{Cl}_{2} \mathrm{C}_{2} \mathrm{H}_{4} \cdot{ }^{\mathrm{b}} \epsilon$ values of oxidized species represent lower limits because of some decomposition during oxidation. ${ }^{\mathrm{c}}$ nd $=$ not determined.
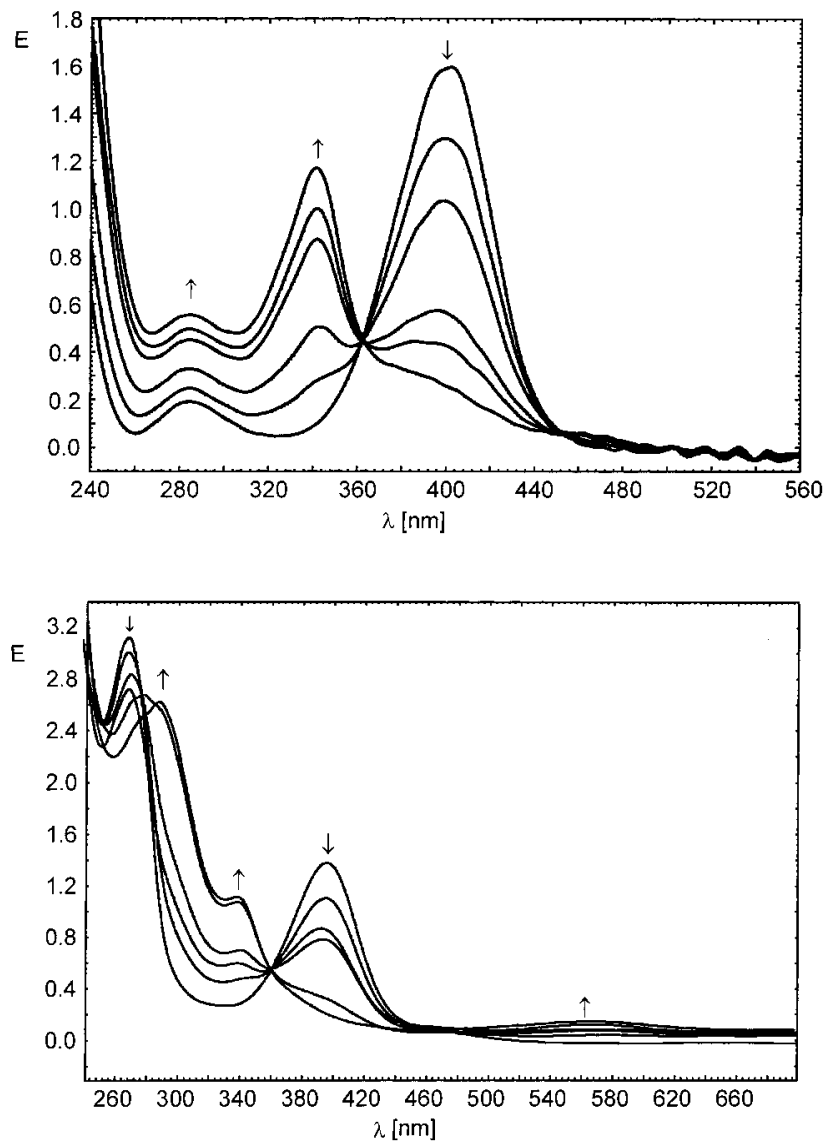

Figure 6. UV/vis spectra recorded during the anodic oxidation of (a, top) compound $\mathbf{4 c}$ and (b, bottom) compound 4d in an OTTLE cell.

cies is observed for complexes where the iminium nitrogen is substituted by two methyl groups, while the frequency increases for $\mathbf{4 d}$, where the iminium nitrogen is part of a saturated six-membered ring.

The most conclusive result as to the oxidation site within complexes $\mathbf{4}$ is expected from EPR spectroscopy. At $95 \mathrm{~K}$ oxidized samples display rhombic patterns with considerable spread of the individual g components and average $g$ values far removed from that of the free electron, indicating a primarily metal-centered oxidation (4c, $g_{x}=2.400, g_{y}=2.067, g_{z}=1.888, g_{a v}=2.118 ; 4 f$, $\left.g_{\mathrm{x}}=2.135, \mathrm{~g}_{\mathrm{y}}=2.022, \mathrm{~g}_{\mathrm{z}}=1.999, \mathrm{~g}_{\mathrm{av}}=2.052\right)$. U pon thawing, EPR activity is reversibly lost.

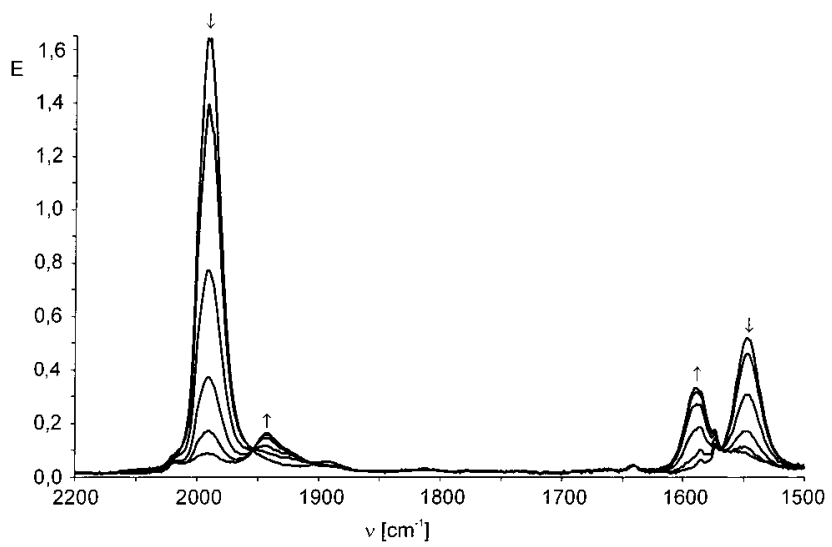

Figure 7. IR spectra recorded during the anodic oxidation of compound $\mathbf{4 c}$ in an OTTLE cell.

Theoretical Calculations. At this point we felt it highly desirable to augment our experimental studies with theoretical calculations. To restrict computational time to a reasonable limit, these were performed on simplified models by replacing the chelating phenyl- or ethyl substituted diphosphine ligands by $\mathrm{PH}_{3}$ and introducing a methyl substituent on the terminal carbon instead of the actual ones in complexes $\mathbf{4 a - f}$. While the latter simplification is expected to have only very minor effects, phosphine substitution certainly has a larger influence due to the differences in electronic properties and PRuP angles ${ }^{4 \mathrm{~b}}$ between the model and our real systems.

(a) The Butatrienylidene Intermediate. While this work was in progress, an exhaustive investigation on cumulene complexes $(\mathrm{CO})_{5} \mathrm{Cr}=\mathrm{C}_{n}=\mathrm{CH}_{2}(\mathrm{n}=1-9)$ on essentially the same theoretical level was published, including the butatrienylidene analogue. ${ }^{18}$ This provides us now with the opportunity to compare crucial parameters of the metallabutatrienylidene entities for $d^{6}$ metal fragments with vastly different electronic properties. Table 5 shows the G98/B3LYP and ADF/BP calculated bond lengths of the ruthenium model complex along with those of its $\mathrm{Cr}(\mathrm{CO})_{5}$ analog ${ }^{18}$ and the experimental structures of trans-[Cl(dppe $\left.)_{2} \mathrm{RuC}_{5} \mathrm{Ph}_{2}\right]^{+11 \mathrm{~b}}$ and of trans$\mathrm{Cl}\left(\mathrm{PiPr}_{3}\right)_{2} \mathrm{IrC}_{4} \mathrm{Ph}_{2}$, the only terminal butatrienylidene complex that has been structurally characterized to date. ${ }^{9}$ The calculated bond lengths within the $\mathrm{C}_{4} \mathrm{H}_{2}$ fragment clearly indicate a cumulenic structure with only a slight progression toward the terminal $\mathrm{CH}_{2}$ 
Table 5. Comparison of Calculated Bond Lengths of $\left[R u C l\left(\mathrm{PH}_{3}\right)_{4} \mathrm{C}_{4} \mathrm{H}_{2}\right]^{+}$with Those for $(\mathrm{CO})_{5} \mathrm{CrC}_{4} \mathrm{H}_{2}{ }^{18}$ and the Experimental Structures of trans-[CI(dppe) $\left.{ }_{2} \mathrm{RuC}_{5} \mathrm{Ph}_{2}\right]^{+11 b}$ and trans-CIIr $\left(\mathrm{PiPr}_{3}\right)_{2} \mathrm{C}_{5} \mathrm{Ph}_{2}{ }^{\mathbf{9}}$

\begin{tabular}{cccccc}
\hline bond & calcd ADF/BP & calcd G98/ B3LYP & calcd $^{a}(\mathrm{CO})_{5} \mathrm{CrC}_{4} \mathrm{H}_{2}$ & {$\left[\mathrm{Cl}(\mathrm{dppe})_{2} \mathrm{RuC}_{5} \mathrm{Ph}_{2}\right]^{+}$} & $\left.\mathrm{ClIr}_{(\mathrm{P}} \mathrm{Pr}_{3}\right)_{2} \mathrm{C}_{5} \mathrm{Ph}_{2}$ \\
\hline $\mathrm{M}-\mathrm{Cl}$ & 2.458 & 2.468 & & $2.430(3)$ & $2.356(2)$ \\
$\mathrm{M}-\mathrm{P}$ & 2.390 & 2.390 & & $2.421(\mathrm{av})$ & $2.353(\mathrm{av})$ \\
$\mathrm{Ru}-\mathrm{C} 1$ & 1.886 & 1.886 & & $1.891(9)$ & $1.816(6)$ \\
$\mathrm{C} 1-\mathrm{C} 2$ & 1.282 & 1.282 & 1.279 & $1.25(1)$ & $1.283(8)$ \\
$\mathrm{C} 2-\mathrm{C} 3$ & 1.290 & 1.297 & 1.285 & $1.30(1)$ & $1.275(8)$ \\
$\mathrm{C} 3-\mathrm{C} 4$ & 1.309 & 1.309 & 1.309 & $1.39^{\mathrm{b}}$ & $1.339(8)$
\end{tabular}

a On the ADF/BP level. b Terminal C.

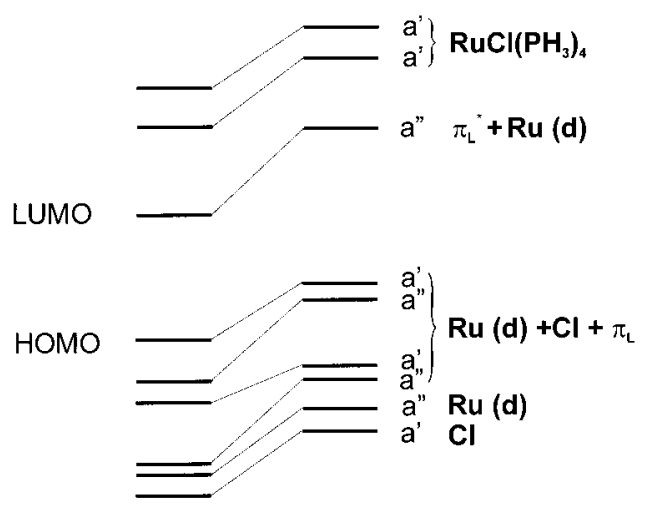

$\{\mathrm{Ru}\} \mathrm{CCCCH}_{2}^{+} \quad\{\mathrm{Ru}\} \mathrm{CCC}\left(\mathrm{N}\left(\mathrm{CH}_{3}\right)_{2}\right) \mathrm{CH}_{3}{ }^{+}$

Figure 8. $\mathrm{MO}$ schemes for the butatrienylidene model complex $\left[\mathrm{Cl}\left(\mathrm{PH}_{3}\right)_{4} \mathrm{RuC}_{4} \mathrm{H}_{2}\right]^{+}$(left) and the aminoallenylidene model complex $\left[\mathrm{Cl}\left(\mathrm{PH}_{3}\right)_{4} \mathrm{RuC}_{3}\left\{\mathrm{~N}\left(\mathrm{CH}_{3}\right)_{2}\right\}\left(\mathrm{CH}_{3}\right)\right]$ (right).

group. Our data are virtually identical with those obtained by Sgamellotti et al. for the $\mathrm{Cr}(\mathrm{CO})_{5}$ derivative and also favorably agree with the experimentally determined data with larger deviations for the terminal $\mathrm{CC}$ bond involving the substituted $\mathrm{sp}^{2}$ center, as expected. The metrical parameters of the butatrienylidene ligand therefore appear to be rather insensitive to the electronic properties of the metal fragment to which it is attached.

A graphic representation of the MO scheme as calculated by the ADF/BP method is given on the left-hand side of Figure 8. As for the $\mathrm{Cr}(\mathrm{CO})_{5}$ analogue of our model complex, the HOMO and the LUMO result from the interaction of the metal fragment $(\mathrm{Cl}, \mathrm{Ru}$, and $\mathrm{P})$ with the occupied or unoccupied $\pi$-orbitals of the cumulene ligand, the HOMO being orthogonal and the LUMO parallel to the plane of the terminal $\mathrm{CH}_{2}$ group. Plots of the frontier orbitals are provided as Figure 9, and the orbital composition is represented in Table 6, while the first row of Table 7 lists the atomic charges from Mulliken analysis. Our ruthenium intermediate follows the same pattern as that established for the $\mathrm{Cr}$ $(\mathrm{CO})_{5}$ complex: the HOMO is dominated by contributions from the metal (30\% in our complex vs 39\% for the $\mathrm{Cr}$ complex) and carbon atoms located at even positions within the $\mathrm{C}_{4}$ chain ( $16 \%$ and $20 \%$ vs $16.5 \%$ and $19 \%$ for $\mathrm{C}_{2}$ and $\mathrm{C}_{4}$, respectively). The opposite holds for the LUMO: here the metal contributes significantly less (17\% for our complex, $13 \%$ for the $\mathrm{Cr}$ system) while more than $70 \%$ arises from the cumulene ligand with dominant contributions from carbon atoms $C_{1}$ and $C_{3}$.

This has a direct bearing on the site of nucleophilic addition to the allenylidene ligand. In principle, the reactivity of our butatrienylidene intermediate could be charge or orbital controlled with either one single factor

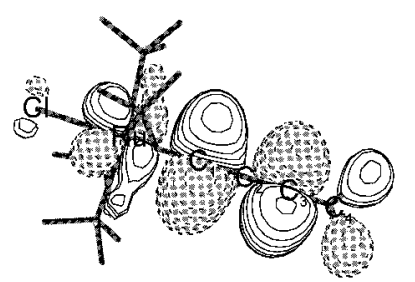

LUMO

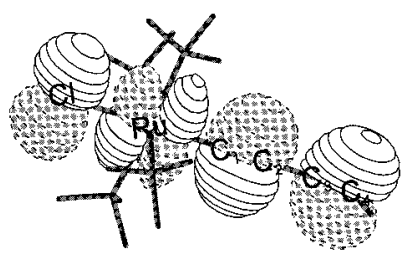

HOMO

Figure 9. Graphic representations of the frontier orbitals of the butatrienylidene model complex $\left[\mathrm{Cl}\left(\mathrm{PH}_{3}\right)_{4} \mathrm{RuC}_{4} \mathrm{H}_{2}\right]^{+}$.

Table 6. ADF Calculated One-E lectron Energies and Percentage Composition of Selected Highest

Occupied and Lowest Unoccupied Molecular Orbitals of [ $\left.\mathrm{Cl}\left(\mathrm{PH}_{3}\right)_{4} \mathrm{RuC}_{4} \mathrm{H}_{2}\right]^{+}$Expressed in Terms of Composing F ragments

\begin{tabular}{|c|c|c|c|c|c|c|c|}
\hline MO & $E(e V)$ & prevailing character & $\mathrm{Ru}$ & $C_{1} C_{2}$ & $\mathrm{C}_{3}$ & $\mathrm{C}_{4}$ & \\
\hline $\begin{array}{l}10 b_{1} \\
\text { occupied }\end{array}$ & -6.99 & $\mathrm{C}_{4} \mathrm{H}_{2}+\mathrm{d}_{\mathrm{Ru}}$ & 17 (d) & 343 & 35 & & \\
\hline & $\begin{array}{l}-8.48 \\
-9.10\end{array}$ & $\mathrm{Ru}+\mathrm{Cl}+\pi^{*} \mathrm{C}_{4} \mathrm{H}_{2}$ & $\begin{array}{l}30(\mathrm{~d}) \\
12(\mathrm{~d})\end{array}$ & $\begin{array}{rr}6 & 16 \\
2 & 2\end{array}$ & 5 & & $\begin{array}{l}22 \\
73\end{array}$ \\
\hline
\end{tabular}

dominating or both being equally important contributors. Charge-control led reactivity requires a significant charge accumulation on one specific center. As shown by Mulliken analysis (see Table 7), the charge differences are rather small, again paralleling the results on the $(\mathrm{CO})_{5} \mathrm{Cr}$ system. ${ }^{18}$ This points to orbital control. There remains, however, the question of why no additi on to the carbon atom adjacent to the metal has been observed to date for butatrienylidene complexes even though the LUMO indicates a rather unselective addition to either $C_{1}$ or $C_{3}$. In fact, cationic allenylidene complexes may display both modes of reactivity, depending on the nature of the metal fragment and the entering nucleophile. ${ }^{26 a}$, $46-51$ Addition to $C_{1}$ requires, however, a metal fragment of only limited steric bulk, offering at least one "open" side with a smaller size ligand for the approach of the incoming nucleophile (e.g. $\left\{\left(\eta^{6} \text {-arene }\right) \mathrm{Ru}\left(\mathrm{PR}_{3}\right) \mathrm{Cl}\right\}^{+}, 50\left\{\left(\eta^{5} \text {-indenyl }\right) \mathrm{Ru}\left(\mathrm{PPh}_{3}\right)(\mathrm{CO})\right\}^{+}, 47 \mathrm{c}$ and $\left.\left\{\mathrm{CpRu}\left(\mathrm{PPh}_{3}\right)(\mathrm{CO})\right\}^{+} 35 \mathrm{~b}, 48 \mathrm{e}, \mathrm{f}\right)$. The only exception seemingly is $\left[\left(\eta^{5} \text {-indenyl }\right) \mathrm{L}_{2} \mathrm{Ru}=\mathrm{C}=\mathrm{C}=\mathrm{CPhH}\right]^{+}\left(\mathrm{L}_{2}=\right.$

(46) (a) Cadierno, V.; Gamasa, M. P.; Gimeno, J.; López-González, M. C.; Borge, J .; García-Granda, S. Organometallics 1997, 16, 4453. (b) Esteruelas, M. E.; Gómez, A. V.; Lahoz, F. J .; López, A. M.; Oñate, E.; Oro, L. A. Organometallics 1996, 15, 3423. 
Table 7. ADF/BP Calculated Mulliken Charges within $\left[\mathrm{Cl}\left(\mathrm{PH}_{3}\right)_{4} \mathrm{RuC}{ }_{3} \mathrm{RR}^{\prime}\right]^{+}$Complexes

\begin{tabular}{|c|c|c|c|c|c|}
\hline \multicolumn{2}{|l|}{$\mathrm{R} / \mathrm{R}^{\prime}$} & \multicolumn{2}{|c|}{$\mathrm{Ru}$} & $\mathrm{C}_{1}$ & $\mathrm{C}_{2}$ \\
\hline \multicolumn{2}{|c|}{$\begin{array}{l}\mathrm{CH}_{2} /- \\
\mathrm{N}\left(\mathrm{CH}_{3}\right)_{2} / \mathrm{CH}_{3}\end{array}$} & \multicolumn{2}{|c|}{$\begin{array}{l}0.605 \\
0.836\end{array}$} & $\begin{array}{l}-0.251 \\
-0.255\end{array}$ & $\begin{array}{l}-0.061 \\
-0.265\end{array}$ \\
\hline \multicolumn{6}{|c|}{$\begin{array}{l}\text { Table 8. ADF-BP Calculated Bond Lengths for } \\
{\left[R \mathbf{u}(\mathrm{CI})\left(\mathrm{PH}_{3}\right)_{4} \mathrm{C}_{3} \mathrm{CH}_{3} \mathrm{~N}\left(\mathrm{CH}_{3}\right)_{2}\right]^{\mathrm{n}+}}\end{array}$} \\
\hline \multirow[b]{2}{*}{ bond } & \multirow[b]{2}{*}{ calcd } & \multicolumn{2}{|c|}{ exptl } & \multirow[b]{2}{*}{ calcd ${ }^{2} A^{\prime}$ state } & \multirow[b]{2}{*}{ calcd ${ }^{2} A^{\prime \prime}$ state } \\
\hline & & $4 a$ & $4 b$ & & \\
\hline $\mathrm{Ru}-\mathrm{Cl}$ & 2.470 & 2.469 & 2.457 & 2.364 & 2.376 \\
\hline Ru-P (av) & 2.349 & 2.350 & 2.399 & 2.405 & 2.395 \\
\hline $\mathrm{Ru}-\mathrm{Cl}$ & 1.957 & 1.950 & 1.934 & 1.951 & 1.971 \\
\hline $\mathrm{C} 1-\mathrm{C} 2$ & 1.256 & 1.218 & 1.232 & 1.257 & 1.251 \\
\hline C2-C3 & 1.379 & 1.372 & 1.393 & 1.394 & 1.402 \\
\hline C3-C4 & 1.504 & 1.499 & 1.48 & 1.500 & 1.497 \\
\hline $\mathrm{C} 3-\mathrm{N}$ & 1.347 & 1.244 & 1.320 & 1.331 & 1.335 \\
\hline $\mathrm{N}-\mathrm{C}\left(\mathrm{CH}_{3}\right)$ & 1.468 & 1.500 & 1.463 & 1.470 & 1.475 \\
\hline
\end{tabular}

dppm, dppe), which adds methanol across the $\mathrm{C}_{1}=\mathrm{C}_{2}$ double bond.20a If, however, two $\mathrm{PPh}_{3}$ ligands are present instead, the nucleophile again adds to $C_{3}$. All this underlines that in rationalizing the regioselectivity of nucleophilic addition on the basis of theory, steric effects cannot be neglected and may even determine the regiochemistry.

(b) Aminoallenylidene Complexes 4. The orbital scheme of the model complex trans- $\left[\mathrm{Cl}\left(\mathrm{PH}_{3}\right)_{4} \mathrm{RuCCC}\right.$ $\left.\left(\mathrm{CH}_{3}\right) \mathrm{N}\left(\mathrm{CH}_{3}\right)_{2}\right]^{+}$, representing our real aminoallenylidene compl exes $\mathbf{4 a - f}$, is displayed on the right-hand side of Figure 8. As shown by the comparison in Table 8, the DFT-optimized geometry reproduces the key features of the experimental structures with reasonable accuracy. While most bond parameters agree within the standard deviations, larger differences are observed for the individual $\mathrm{C}-\mathrm{N}$ bonds, which, however, suffer from some disorder of the $\mathrm{NMe}_{2}$ unit and the butenyl side chain in the experimental structures.

Again, the crucial orbital interactions in the frontier orbitals involve the metal fragment and the unsaturated ligand. As shown in Table 9, the highest occupied levels are largely made up of the ruthenium and chlorine atoms (SHOMO, 80\%; HOMO, 79\%; SHOMO = second

(47) (a) Cadierno, V.; Gamasa, M. P.; Gimeno, J .; Lastra, E. J Organomet. Chem. 1994, 474, C27. (b) Cadierno, V.; Gamasa, M. P.; Gimeno, J .; Borge, J .; Garcĺa-Granda, S. J . Chem. Soc., Chem. Commun. 1994, 2495. (c) Gamasa, M. P.; Gimeno, J .; GonzálezBernardo, C.; Borge, J .; García-Granda, S. Organometallics 1997, 16, 2483. (d) Cadierno, V.; Gamasa, M. P.; Borge, J . Organometallics 1997, 16, 3178. (e) Cadierno, V.; Gamasa, M. P.; Gimeno, J .; López-González, M. C.; Borge, J .; García-Granda, S. Organometallics 1997, 16, 4453. (f) Cadierno, V.; Gamasa, M. P.; Gimeno, J .; Pérez-Carreño, E.; I lenco, E. Organometallics 1998, 17, 5216

(48) (a) Pirio, N.; Touchard, D.; Dixneuf, P. H. J . Chem. Soc., Chem. Commun. 1991, 980. (b) Pirio, N.; Touchard, D.; Dixneuf, P. H. J. Organomet. Chem. 1993, 462, C18. (c) Touchard, D.; Pirio, N.; Dixneuf, P. H. Organometallics 1995, 14, 4920. (d) Esteruelas, M. E.; Gómez, A. V.; López, A. M.; Puerta, M. C.; Valerga, P. Organometallics 1998, 17, 4959. (e) Esteruelas, M. E.; Gómez, A. V.; López, A. M.; Modrego, J .; Oñate, E. Organometallics 1998, 17, 5434. (f) Bernard, D. J.; Esteruelas, M. E.; López, A. M.; Modrego, J .; Puerta, M. C.; Valerga, P. Organometallics 1999, 18, 4995

(49) (a) Werner, H.; Wiedemann, R.; Laubender, M.; Wolf, J .; Windmüller, B. J . Chem. Soc., Chem. Commun. 1996, 1413. (b) Werner, H.; Wiedemann, R.; Steinert, P.; Wolf, J . Chem. Eur. J . 1997, 3, 127. (c) Laubender, M.; Werner, H. Ángew. Chem. 1998, 110, 158.

(50) Ouzzine, K.; Dixneuf, P. H. J . Chem. Soc., Chem. Commun. 1989, 219. (b) Pilette, D.; Ouzzine, K.; Le Bozec, H.; Dixneuf, P. H.; Rickard, C. E. F.; Roper, W. E. Organometallics 1992, 11, 809. (c) Touchard, D.; Pirio, N.; Dixneuf, P. H. Organometallics 1995, 14, 4920.

(51) Bruce, M. I.; Low, P. J .; Tiekink, E. R. T. J . Organomet. Chem. $1999,572,3$.

charge on

\begin{tabular}{ccccc}
\multicolumn{1}{c}{$\mathrm{C}_{3}$} & $\mathrm{R}$ & $\mathrm{R}^{\prime}$ & $\mathrm{Cl}$ & $\mathrm{PH}_{3}$ \\
\hline 0.111 & $-0.074(\mathrm{C})$ & & -0.371 & 0.260 \\
-0.118 & $-0.128(\mathrm{~N})$ & $-0.128(\mathrm{C})$ & -0.420 & 0.120
\end{tabular}

Table 9. ADF Calculated One-Electron Energies and Percentage Composition of Selected Highest Occupied and Lowest Unoccupied Molecular Orbitals of $\left[\mathrm{Cl}\left(\mathrm{PH}_{3}\right)_{4} \mathrm{RuC}_{3}\left(\mathrm{CH}_{3}\right)\left(\mathrm{N}_{\left.\left.\left(\mathrm{CH}_{3}\right)_{2}\right)\right]^{+}}\right.\right.$ Expressed in Terms of Composing Fragments

\begin{tabular}{|c|c|c|c|c|c|c|c|c|}
\hline MO & $E(e V)$ & $\begin{array}{l}\text { prevailing } \\
\text { character }\end{array}$ & Ru & $\mathrm{C}_{1}$ & $\mathrm{C}_{2}$ & $\mathrm{C}_{3}$ & $\mathrm{~N}\left(\mathrm{CH}_{3}\right)_{2}$ & $\mathrm{Cl}$ \\
\hline \multicolumn{9}{|l|}{ unocc } \\
\hline $33 a^{\prime}$ & -4.61 & $\mathrm{Ru}(\mathrm{Cl})\left(\mathrm{PH}_{3}\right)_{4}$ & $32(d)$ & & & & & 12 \\
\hline $32 a^{\prime}$ & -5.00 & $\mathrm{Ru}(\mathrm{Cl})\left(\mathrm{PH}_{3}\right)_{4}$ & 41 (d) & & & & & \\
\hline 16a" & -5.90 & $\pi^{*} \mathrm{R}^{\prime}+\mathrm{d}_{\mathrm{Ru}}$ & 10 (d) & 27 & 2 & 34 & 18 & 1 \\
\hline \multicolumn{9}{|l|}{ OCC } \\
\hline $31 a^{\prime}$ & -7.85 & $\mathrm{Ru}+\mathrm{Cl}+\pi^{*} \mathrm{R}^{\prime}$ & $35(d)$ & 1 & 14 & 1 & 0 & 44 \\
\hline $15 a^{\prime \prime}$ & -8.06 & $\mathrm{Ru}(\mathrm{Cl})\left(\mathrm{PH}_{3}\right)_{4}$ & 23 (d) & 0 & 6 & 2 & 5 & 57 \\
\hline $30 a^{\prime}$ & -8.88 & $\mathrm{Ru}+\mathrm{Cl}+\pi^{*} \mathrm{R}^{\prime}$ & 13 & 11 & 20 & 1 & 0 & 41 \\
\hline $14 a^{\prime \prime}$ & -9.06 & $\mathrm{Ru}+\mathrm{Cl}+\pi^{*} \mathrm{R}^{\prime}$ & 17 & 6 & 19 & 1 & 14 & 28 \\
\hline 13a" & -9.44 & $\mathrm{Ru}(\mathrm{Cl})\left(\mathrm{PH}_{3}\right)_{4}$ & 74 & & & & & \\
\hline
\end{tabular}

highest occupied molecular orbital) with only smaller contributions of the aminoallenylidene ligand (SHOMO, $13 \%$; HOMO, 16\%) mainly arising from $\mathrm{C}_{2}$. The LUMO, in contrast, is delocalized over the unsaturated ligand (81\%) with major contributions from $\mathrm{C}_{1}, \mathrm{C}_{3}$, and the $\mathrm{N}\left(\mathrm{CH}_{3}\right)_{2}$ substituent. The contributions of the metal and the chlorine are concomitantly small (10\%). This pattern qualitatively agrees with that for the related all-carbonsubstituted al lenylidene complexes [Cp(CO) $\left(\mathrm{PH}_{3}\right)=\mathrm{C}=$ $\left.\mathrm{C}=\mathrm{CH}_{2}\right]^{+20 \mathrm{~b}}$ and $\left[\mathrm{CpL}(\mathrm{PH})_{3} \mathrm{Os}=\mathrm{C}=\mathrm{C}=\mathrm{CH}_{2}\right]^{\mathrm{n}+}(\mathrm{L}=\mathrm{Cl}$, $\left.\mathrm{n}=0 ; \mathrm{L}=\mathrm{PH}_{3}, \mathrm{CO}, \mathrm{n}=1\right)^{20 \mathrm{c}}$ calculated at the $\mathrm{EHT}$ level, where the allenylidene ligand contributes about $25-30 \%$ to the HOMO and some $60-64 \%$ to the LUMO. Introducing an amino substituent at $\mathrm{C}_{3}$ seemingly has a 2-fold effect in comparison to all-carbon-substituted analogues: the HOMO and the LUMO are even more localized on the metal and the allenylidene ligand, respectively. Second, as based on Mulliken analysis (see Table 7), the charge is distributed much more evenly over the aminoallenylidene ligand, as compared to related complexes of the parent allenylidene ligand, which indicates a somewhat smaller polarization of the unsaturated chain.

The close-lying occupied 15a" and 31a' and the lowest unoccupied 16a" orbitals deserve some more comment, since they form the key to undestanding the optical properties of our aminoallenylidene complexes. Plots of these frontier orbitals are presented in Figure 10. In the SHOMO and the LUMO the $\pi$-system of the aminoallenylidene ligand is orthogonal to the $\mathrm{RuC}_{3}\left(\mathrm{CH}_{3}\right)$ $\left(\mathrm{N}\left(\mathrm{CH}_{3}\right)_{2}\right)$ plane, while it is parallel for the HOMO. The HOMO/LUMO transition is thus symmetry-forbidden, while the SHOMO/LUMO transition is symmetryallowed, as is experimentally observed. Foll owing from the above discussion, both transitions have strong MLCT character. The two other features in our experimental spectra are assigned as follows. The less intense absorption at ca. $450 \mathrm{~nm}$ superimposed on the lowenergy side of the SHOMO/LUMO absorption band is proposed to arise from the spin-forbidden singlet-triplet SHOMO/LUMO transition. The rather intense highenergy band at ca. 265-290 nm, often obscured by the $\mathrm{PPh}_{2}$-based transitions but cl early visible as an isolated 


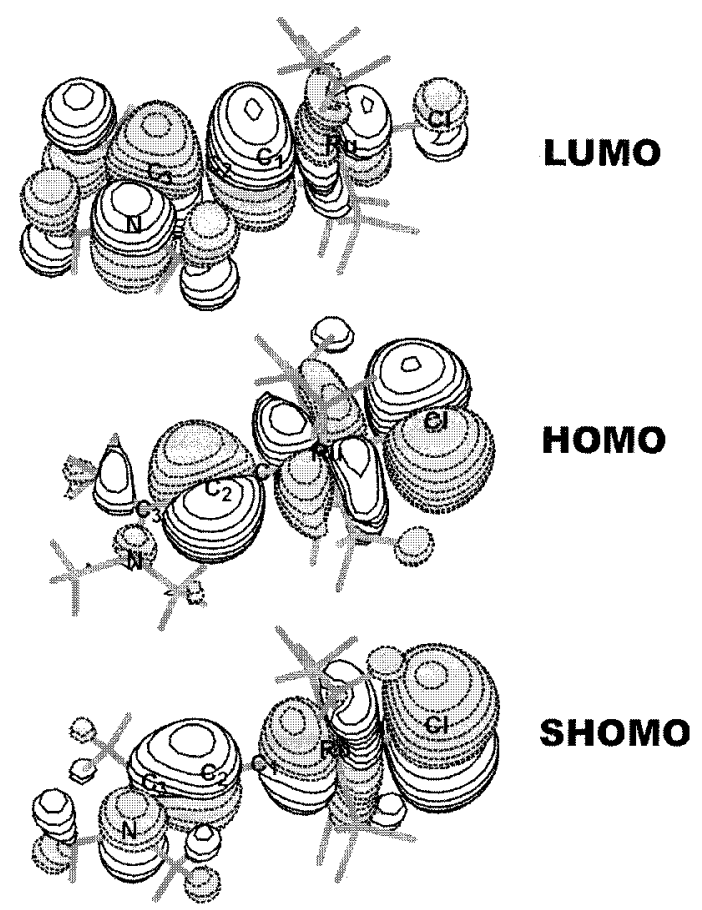

Figure 10. Graphic representations of the frontier orbitals of the aminoallenylidene model complex $\left[\mathrm{Cl}\left(\mathrm{PH}_{3}\right)_{4} \mathrm{RuC}_{3}-\right.$ $\left.\left\{\mathrm{N}\left(\mathrm{CH}_{3}\right)_{2}\right\}\left(\mathrm{CH}_{3}\right)\right]^{+}$.

band for the depe complex $\mathbf{4 c}$, results from an excitation into the LUMO from the lower lying 14a" level. To further support our assignments, the energetically lowest transitions as well as their oscillator strengths were calculated by time-dependent (TD) DFT methods within the G98/B3LYP and the ADF/BP approximations. The results reasonably agree with our experimental data, as shown by the comparison in Table 10. Although the absolute values of transition energies and oscillator strengths clearly depend on the computational method employed, the data correctly reproduce the sequence of transitions and, at least qualitatively, the relative band intensities.

One last point concerns the assignment of the two prominent infrared bands in the $2000-1500 \mathrm{~cm}^{-1}$ region. Frequency calculations based on the G98/B3LYP method place the first band at $1998 \mathrm{~cm}^{-1}$. This band is essentially the symmetric stretch of the $\mathrm{C}_{1} \mathrm{C}_{2}$ bond invol ving the carbon atom directly attached to the metal. The second feature is calculated to occur at $1524 \mathrm{~cm}^{-1}$. It arises from the $\mathrm{C}=\mathrm{N}$ stretch coupled with the bending of the three methyl groups surrounding the iminium moiety.

Consequences of Electron Transfer on the Bonding. One important question is how electron transfer from aminoall enylidene complexes $\mathbf{4}$ affects the bonding within these systems. Geometry optimization of the oxidized forms was performed in the ${ }^{2} A^{\prime}$ and ${ }^{2} A^{\prime \prime}$ states, which differ in the ordering of the 16a" and 32a' levels. We note that the UV/vis spectra suggest that the level ordering 16a" < 32a' is maintained in the oxidized state. Our calculations indicate that most of the structural reorganization is confined to the $\mathrm{CIP}_{4} \mathrm{Ru}$ fragment (see Table 8). The most important structural changes are the shortening of the $\mathrm{Ru}-\mathrm{Cl}$ bond by about $0.1 \AA$ and the lengthening of the Ru-P bonds by about $0.05 \AA$. This is easily understood on the basis of our DFT calculations and the $\mathrm{Ru}(\mathrm{II} / \mathrm{III})$ character of the oxidation process. The highest lying occupied levels are both $\mathrm{Ru}-\mathrm{Cl}$ antibonding in nature: hence, the $\mathrm{Ru}-\mathrm{Cl}$ bond shortening. U pon oxidation, the metal center loses electron density, which leads to smaller back-donation to the $\pi$-acidic phosphine ligands, in accord with the lengthening of the Ru-P bonds. This is consistent with experimental evidence from the complexes $\left[\mathrm{MXY}\left(\mathrm{L}_{2}\right)_{2}\right]\left(\mathrm{X}, \mathrm{Y}=\mathrm{CN}, \mathrm{Cl}, \mathrm{L}_{2}=2\right.$ $\mathrm{PR}_{3}$, chelating diphosphine), which have been characterized crystallographically in both adjacent oxidation states. ${ }^{52}$ In contrast, the metrical parameters of the aminoal lenylidene ligand change to only a very minor degree with some lengthening of the $\mathrm{C}_{2}-\mathrm{C}_{3}$ and some shortening of the $\mathrm{C}_{3}-\mathrm{N}$ bond. These structural changes taken per se are best interpreted in terms of an even higher weight of the iminium alkynyl type resonance form in the oxidized state, i.e., trans- $\left[\mathrm{Cl}(\mathrm{dppm})_{2} \mathrm{Ru}^{\prime}-\mathrm{C} \equiv\right.$ $\left.\mathrm{CC}\left(=\mathrm{NMe}_{2}\right) \mathrm{CH}_{3}\right]^{2+}$, consistent with a metal-based oxidation process.

With their characteristic and intense $\mathrm{C} \equiv \mathrm{C}$ and $\mathrm{C}=\mathrm{N}$ IR bands, aminoallenylidene complexes 4 appear especially well suited to monitor changes in the bonding sequence al ong the unsaturated ligand by spectroelectrochemistry. The direction of the band shift is of special relevance: For mononuclear alkynyl complexes a moderate shift of the $\mathrm{C} \equiv \mathrm{C}$ stretch to higher energies usually accompanies oxidation, although some results to the contrary have also been reported. ${ }^{33}$ In particular, the latter situation holds if the oxidation leads to a higher contribution of a cumulene type resonance form, as observed for ferrocenyl- or ruthenocenyl-acetylide complexes ${ }^{52}$ or with $\mathrm{C}_{4}$-bridged dimetal complexes. ${ }^{2-5}$ Band shifts are considerably higher in this case, often exceeding $100 \mathrm{~cm}^{-1}$. With reference to Table 4, it is difficult to reconcile our experimental data with the results from theory. In every case the CC band is displaced to considerably lower energy upon oxidation. With the exception of the piperidine-substituted complex 4d, where the piperidine ring may act as a stronger donor in the oxidized state, the same also holds for the $\mathrm{C}=\mathrm{N}$ stretch. Both observations rather agree with a higher cumulenic character in the Ru(III) state. On the other hand, we have observed an exactly opposite shift of $v_{\mathrm{CC}}$ from 1997 to $2022 \mathrm{~cm}^{-1}$ for the second, rutheniumbased oxidation of the aminoallenylidene complex [Cl$\left.(\mathrm{dppm})_{2} \mathrm{Ru}-\mathrm{C} \equiv \mathrm{CC}\left(=\mathrm{NMe}_{2}\right) \mathrm{C}_{2} \mathrm{H}_{4} \mathrm{FC}\right]^{+}$with an appended redox-active ferrocenyl ( $\mathrm{FC}$ ) moiety. At this point we cannot offer a conclusive explanation for this apparently controversial behavior. Another striking observation is the large decrease in absorptivity of the CC band upon oxidation to the Ru(III) di cations. Our working hypothesis is as follows: in the oxidized state the $C_{1} C_{2}$ unit bridges two positively charged centers (the metal and the heteroatom), and this is expected to decrease the di pol e moment change during the symmetric stretch as opposed to the monocationic Ru(II) state. Interestingly, and in good agreement with this view, the CC band is

(52) (a) Carvalho, M. F. N. N.; Duarte, M. T.; Galvão, A. M.; Pombeiro, A. J . L.; Henderson, R.; Fuess, H.; Svoboda, I.J . Organomet. Chem. 1999, 583, 56. (b) Salih, T. A.; Duarte, M. T.; Fraústo da Silva, J. J. R.; Galvão, A. M.; Guedes da Silva, M. F. C.; Hitchcock, P. B.; Hughes, D. L.; Pickett, C. J .; Pombeiro, A. J . L.; Richards, R. L. J . Chem. Soc., Dalton Trans. 1993, 3015. 
Table 10. Lowest Calculated TD DFT Excitation Energies (eV) for $\left[\mathrm{Cl}\left(\mathrm{PH}_{3}\right)_{4} \mathrm{RuC}_{3}\left(\mathrm{CH}_{3}\right)\left(\mathrm{N}_{(}\left(\mathrm{CH}_{3}\right)_{2}\right)\right]^{+}$

\begin{tabular}{|c|c|c|c|c|c|c|c|}
\hline \multirow[b]{2}{*}{ state } & \multirow[b]{2}{*}{ main components } & \multicolumn{2}{|c|}{ G98/B3LYP } & \multicolumn{2}{|c|}{ ADF/BP } & \multirow[b]{2}{*}{$\begin{array}{c}\text { exptl transition, } \\
\mathbf{4 c}(\mathrm{eV})\end{array}$} & \multirow[b]{2}{*}{$\log \epsilon$} \\
\hline & & $\begin{array}{l}\text { transition } \\
\text { energy }(\mathrm{eV})\end{array}$ & osc ${ }^{a}$ str & $\begin{array}{l}\text { transition } \\
\text { energy }(\mathrm{eV})\end{array}$ & osc $^{\mathrm{a}} \mathrm{str}$ & & \\
\hline${ }^{3} A^{\prime \prime}$ & $99 \%\left(31 a^{\prime} \rightarrow 16 a^{\prime \prime}\right)$ & 2.29 & & 1.91 & & & \\
\hline${ }^{1} A^{\prime \prime}$ & $99 \%\left(31 a^{\prime} \rightarrow 16 a^{\prime \prime}\right)$ & 2.43 & 0.000 & 1.98 & 0.0001 & 1.97 & 2.58 \\
\hline${ }^{3} A^{\prime}$ & $98 \%\left(15 a^{\prime \prime} \rightarrow 16 a^{\prime \prime}\right)$ & 2.48 & & 2.04 & & 2.52 & 2.55 \\
\hline${ }^{1} A^{\prime}$ & $88 \%\left(15 a^{\prime \prime} \rightarrow 16 a^{\prime \prime}\right)$ & 3.31 & 0.271 & 2.53 & 0.120 & 3.10 & 4.34 \\
\hline${ }^{1} A^{\prime}$ & $98 \%\left(31 a^{\prime} \rightarrow 32 a^{\prime}\right)$ & 3.51 & 0.007 & 2.96 & 0.001 & nob & no \\
\hline${ }^{1} A^{\prime}$ & 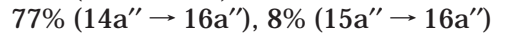 & 4.106 & 0.201 & 3.85 & 0.285 & 4.32 & 3.06 \\
\hline${ }^{1} A^{\prime}$ & $98 \%\left(30 a^{\prime} \rightarrow 32 a^{\prime}\right)$ & & & 3.95 & 0.001 & & \\
\hline
\end{tabular}

reported to also be much weaker in neutral allenylidene complexes than in monocationic ones. ${ }^{54}$

\section{Conclusion}

Aminoallenylidene complexes trans-[Cl $\left(\mathrm{L}_{2}\right)_{2} \mathrm{RuCCC}$ $\left.\left(\mathrm{NR}_{2}\right)\left(\mathrm{CH}_{2} \mathrm{R}^{\prime}\right)\right]^{+}(\mathbf{4})$ are accessible by a one-pot procedure where the unsaturated $\mathrm{C}_{7} \mathrm{~N}$ ligand is assembled from butadiyne and an allylic or propargylic amine via primary butatrienylidene complexes trans- $\left[\mathrm{Cl}\left(\mathrm{L}_{2}\right)_{2} \mathrm{Ru}=\right.$ $\left.\mathrm{C}=\mathrm{C}=\mathrm{C}=\mathrm{CH}_{2}\right]^{+}$as the reactive intermediates and amine adducts trans- $\left[\mathrm{Cl}\left(\mathrm{L}_{2}\right)_{2} \mathrm{Ru}-\mathrm{C} \equiv \mathrm{CC}\left(\mathrm{NR}_{2} \mathrm{R}^{\prime}\right)=\mathrm{CH}_{2}\right]^{+}$formed by nucleophilic addition to the cumulated $\mathrm{C}_{4}$ ligand. If $\mathrm{R}^{\prime}$ is an allylic moiety, the amine adducts rearrange under mild conditions via an Aza-Cope type process to their aminoallenylidene isomers, whereas in the propargylic case the barrier is higher such that the primary adduct is isolable and its rearrangement can be independently studied. Along the continuum between true cumulenic $\left[\{\mathrm{Ru}\}=\mathrm{C}=\mathrm{C}=\mathrm{C}\left(\mathrm{ER}_{\mathrm{n}}\right) \mathrm{R}^{\prime}\right]^{+}$and alkynyl type $\left[\{\mathrm{Ru}\}-\mathrm{C} \equiv \mathrm{CC}\left(=\mathrm{ER} \mathrm{R}_{\mathrm{n}}\right) \mathrm{R}^{\prime}\right]^{+}$resonance descriptions, ${ }^{13 \mathrm{c}}$ aminoallenylidene complexes so far display the highest alkynyl character of the whole series $E R_{n}=N R_{2}, O R$, $\mathrm{SR}, \mathrm{SeR}, \mathrm{CR}_{3}$. Indications are the energy barriers for rotation around the $\mathrm{C}=\mathrm{N}$ bond in NMR spectroscopy, the position of the $\mathrm{Ru}-\mathrm{C}_{1} \mathrm{C}_{2}$ stretch and the intense $\mathrm{C}=$ $\mathrm{N}$ band at ca. $1550 \mathrm{~cm}^{-1}$ in their IR spectra, and the considerable bond length alternation along the $\mathrm{RuC}_{3} \mathrm{~N}$ entity with a short $\mathrm{C} 3-\mathrm{N}$ bond and planar coordination of the iminium nitrogen, as established by X-ray crystallography. The role of the metal center is evident from complexes $\mathbf{4 a}-\mathbf{c}$, which only differ in their diphosphine chelate ligands. A more basic metal fragment enhances the cumulenic character of the allenylidene chain.

DFT calculations on a simplified model of our proposed butatrienylidene intermediate establish that combined orbital (i.e. the orbital coefficients at the LUMO) and steric (i.e. the shielding of $C_{1}$ by the bulky coligands on the metal) effects are responsible for the highly regiosel ective nucleophilic attack on $\mathrm{C}_{3}$. Our results on the aminoallenylidene model complex trans- $\left[\mathrm{Cl}\left(\mathrm{PH}_{3}\right)_{4}{ }^{-}\right.$ RuCCC $\left.\left\{\mathrm{N}\left(\mathrm{CH}_{3}\right)_{2}\right\}\left(\mathrm{CH}_{3}\right)\right]^{+}$support the idea of a metalbased oxidation and a ligand-based reduction, ${ }^{13 c}$ which is fully consistent with our experimental results. These calculations also aid in the assignment of the main absorption bands in their electronic and IR spectra.

(53) (a) Sato, M.; Hayashi, Y.; Kumakura, S.; Shimizu, N.; Katada, M.; Kawata, S. Organometallics 1996, 15, 761. (b) Sato, M.; Kawata Y.: Shintate, H.; Habata, Y.; Akabori, S.; Unoura, K. Organometallics 1997, 16, 1693. (c) Sato, M.; I wai, A.; Watanabe, M. Organometallics 1999, 18, 3208.

(54) Harlow, K. J .; Hill, A. F.; Wilton-Ely, J . D. E. T. J . Chem. Soc., Dalton Trans. 1999, 285.

\section{Experimental Section}

All manipulations were performed by standard Schlenk techniques under an argon atmosphere. Dichloromethane, hexanes, and acetonitrile were dried by disitillation from $\mathrm{CaH}_{2}$; xylene was dried over sodium. o-Dichlorobenzene was used without further purification. All solvents were degassed by either at least three freeze-pump-thaw cycles or saturation with argon prior to use. $\mathrm{RuCl}_{2}(\mathrm{dmso})_{4}{ }^{55}$ and cis- $\mathrm{RuCl}_{2}(\mathrm{dppm})_{2}{ }^{56}$ were obtained according to literature methods, while trans$\mathrm{RuCl}_{2}(\mathrm{dppe})_{2}$ was prepared as outlined below. Butadiyne was prepared from 1,4-dichloro-2-butyne as detailed in an earlier publication ${ }^{13 d}$ and isolated at $195 \mathrm{~K}$ as a white, crystalline solid. Caution! Butadiyneshould behandled and stored under rigorous exclusion of air and at temperatures bel ow $230 \mathrm{~K}$. The respective amines were obtained from commercial sources or prepared from their hydrochlorides by standard procedures and distilled from $\mathrm{KOH}$ before use. Yields given for complexes $\mathbf{3 f ,} \mathbf{g}$ and $\mathbf{4 a}-\mathbf{f}$ are based on cis- $\mathrm{RuCl}_{2}(\mathrm{dppm})_{2}$. I nfrared spectra were obtained on a Perkin-Elmer Paragon 1000 PC FT-IR instrument. ${ }^{1} \mathrm{H}(250.13 \mathrm{MHz}),{ }^{13} \mathrm{C}(62.90 \mathrm{MHz})$, and ${ }^{31} \mathrm{P} \mathrm{NMR}$ spectra $(101.26 \mathrm{MHz})$ were recorded on a Bruker AC 250 spectrometer at $303 \mathrm{~K}$ in the solvent indicated. The spectra were referenced to residual protonated solvent $\left({ }^{1} \mathrm{H}\right)$, the solvent signal itself ${ }^{13} \mathrm{C}$ ), or external $\mathrm{H}_{3} \mathrm{PO}_{4}\left({ }^{31} \mathrm{P}\right)$. The assignment of ${ }^{13} \mathrm{C}$ NMR spectra was aided by DEPT-135 experiments. UV/ vis spectra were obtained on a Shimadzu UV-160 spectrometer or an Omega 10 spectrometer from Bruins Instruments. The EPR equipment consists of a Bruker ESP 3000 spectrometer equipped with an HP frequency counter 5350 B, a Bruker NMR gaussmeter ER $035 \mathrm{M}$, and a continuous flow cryostat ESR 900 from Oxford I nstruments for low-temperature work. Elemental analyses $(\mathrm{C}, \mathrm{H}, \mathrm{N})$ were performed at in-house facilities. All electrochemical experiments were performed in a home-built cylindrical vacuumtight one-compartment cell. A spiral-shaped Pt wire and an Ag wire as the counter and reference electrodes are sealed directly into opposite sides of the glass wall while the respective working electrode (Pt or glassy carbon $1.1 \mathrm{~mm}$ polished with $0.25 \mu \mathrm{m}$ diamond paste (Buehler-Wirtz) before each experiment) is introduced via a Teflon screw cap with a suitable fitting. The cell may be attached to a conventional Schlenk line via two side arms equipped with Teflon screw valves and allows experiments to be performed under an atmosphere of argon with approximately $2.5 \mathrm{~mL}$ of analyte solution. Solvents for electrochemistry were obtained in the highest available purity from commercial sources $\left(\mathrm{CH}_{2} \mathrm{Cl}_{2}\right.$ and $1,2-\mathrm{C}_{2} \mathrm{H}_{4} \mathrm{Cl}_{2}$ from Fluka (Burdick\&J ackson brand), $\mathrm{CH}_{3} \mathrm{CN}$ (HPLC gradient grade) from Roth, THF (99.9\%) from Aldrich) and freshly distilled from $\mathrm{CaH}_{2}\left(\mathrm{CH}_{2} \mathrm{Cl}_{2}, 1,2-\mathrm{C}_{2} \mathrm{H}_{4} \mathrm{Cl}_{2}, \mathrm{CH}_{3} \mathrm{CN}\right)$ or $\mathrm{K}$ (THF) before use. $\mathrm{NBu}_{4} \mathrm{PF}_{6}(0.25 \mathrm{mM})$ was used as the supporting electrolyte. All potentials are reported relative to the internal ferrocene/ferrocenium couple. Electrochemical data were ac-

(55) Evans, I. P.; Spencer, A.; Wilkinson, G. J . Chem. Soc., Dalton Trans. 1973, 204.

(56) Chaudret, B.; Commenges, G.; Poilblanc, R. J . Chem. Soc., Dalton Trans. 1984, 1635. 
quired with a computer-controlled EG\&G Model 273 potenti ostat utilizing the EG\&G 250 software package. The OTTLE cell was also home-built and comprises a Pt-mesh working and counter el ectrode and a thin silver wire as a pseudo-reference electrode sandwiched between the $\mathrm{CaF}_{2}$ windows of a conventional liquid IR cell. The working electrode is positioned in the center of the spectrometer beam.

Calculations. Ground-state el ectronic structure calculations on $\left[\mathrm{Cl}\left(\mathrm{PH}_{3}\right)_{4} \mathrm{RuC}_{3}\left\{\mathrm{~N}\left(\mathrm{CH}_{3}\right)_{2}\right\} \mathrm{CH}_{3}\right]^{+}$and $\left[\mathrm{CIRu}\left(\mathrm{PH}_{3}\right)_{4} \mathrm{C}_{4} \mathrm{H}_{2}\right]^{+}$ have been performed by density functional theory (DFT) methods using the Amsterdam density functional (ADF 1999) ${ }^{57,58}$ and Gaussian $98^{59}$ program packages. The lowest excited states of the closed-shell complexes were calculated by the timedependent DFT method (ADF-RESPONSE ${ }^{60}$ program and Gaussian 98). Within Gaussian 98 Dunning's valence double- $\xi$ functions ${ }^{60}$ with polarization functions were used for $\mathrm{C}, \mathrm{N}$, and $\mathrm{H}$ atoms and the effective quasirelativistic effective core pseudopotentials and corresponding optimized set of basis functions for $\mathrm{P},{ }^{61} \mathrm{Cl},{ }^{61}$ and $\mathrm{Ru}^{62}$ atoms. A hybrid Becke threeparameter functional with Lee, Yang, and Parr correlation functional (B3LYP)63 was used in Gaussian 98 calculations (G98/B3LYP). Within the ADF program Slater type orbital (STO) basis sets of double $\xi$ quality with polarization functions for $\mathrm{H}, \mathrm{C}, \mathrm{N}, \mathrm{P}$, and $\mathrm{Cl}$ atoms and triple- $\xi$ functions for Ru were employed. Inner shells were treated within the frozen-core approximation (1s for $\mathrm{C}$ and $\mathrm{N}, 1 \mathrm{~s}-2 \mathrm{p}$ for $\mathrm{P}$ and $\mathrm{Cl}, 1 \mathrm{~s}-3 \mathrm{~d}$ for $\mathrm{Ru}$ ). Local density approximation (LDA) with VWN parametrization of electron gas data, including Becke's gradient correction ${ }^{64}$ to the local exchange expression in conjunction with Perdew's gradient correction ${ }^{65}$ to the LDA correlation, was used (ADF/BP). The scalar relativistic (SR) zero-order regular approximation (ZORA) was used within this study. The adiabatic local density approximation (ALDA), with the frequency dependence ignored, was used in post-SCF timedependent DFT calculations (TD-DFT). The calculated IR frequencies were scaled as recommended for DFT calculations with the double- $\xi$ basis set. ${ }^{66}$ Due to their size the real complexes were approximated by model systems where Pcontaining ligands were replaced by $\mathrm{PH}_{3}$ groups. The sym-

(57) Baerends, E. J .; Bérces, A.; Bo, C.; Boerrigter, P. M.; Cavallo, L.; Deng, L.; Dickson, R. M.; Ellis, D. E.; Fan, L.; Fischer, T. H.; Fonseca Guerra, C.; van Gisbergen, S. J . A.; Groeneveld, J . A.; Gritsenko, O. V.; Harris, F. E.; van den Hoek, P.; J acobsen, H.; van Kessel, G.; Kootstra, F.; van Lenthe, E.; Osinga, P. V.; Philipsen, P. H. T.; Post, D.; Pye, C. C.; Ravenek, W.; Ros, P.; Schipper, P. R. T.; Schreckenbach, G.; Snijders, J . G.; Sola, M.; Swerhone, D.; te Velde, G.; Vernooijs, P.; Versluis, L.; Visser, O.; van Wezenbeek, E.; Wiesenekker, G.; Wolff, S. K.: Woo, T. K.: Ziegler, T. ADF 1999.01; Amsterdam, 1999.

(58) Fonseca Guerra, C.; Snijders, J . G.; te Velde, G.; Baerends, E. J . Theor. Chem. Acc. 1998, 99, 391.

(59) Frisch, M. J .; Trucks, G. W.; Schlegel, H. B.; Scuseria, G. E.; Robb, M. A.; Cheeseman, J . R.; Zakrzewski, V. G.; Montgomery, J . A., J r.; Stratmann, R. E.; Burant, J . C.; Dapprich, S.; Millam, J. M.; Daniels, A. D.; Kudin, K. N.; Strain, M. C.; Farkas, O.; Tomasi, J .; Barone, V.: Cossi, M.; Cammi, R.; Mennucci, B.; Pomelli, C.; Adamo, C.; Clifford, S.; Ochterski, J .; Petersson, G. A.; Ayala, P. Y.; Cui, Q.; Morokuma, K.; Malick, D. K.; Rabuck, A. D.; Raghavachari, K.; Foresman, J . B.; Cioslowski, J .; Ortiz, J . V.; Stefanov, B. B.; Liu, G.; Liashenko, A.; Piskorz, P.; Komaromi, I.; Gomperts, R.; Martin, R. L.; Fox, D. J .; Keith, T.; Al-Laham, M. A.; Peng, C. Y.; Nanayakkara, A.; Gonzalez, C.; Challacombe, M.; Gill, P. M. W.; J ohnson, B.; Chen, W.; Wong, M. W.; Andres, J . L.; Gonzalez, C.; Head-Gordon, M.; Replogle, E. S.; Pople, I. A. Gaussian 98, Revision A.7; Gaussian, Inc.: Pittsburgh, PA, 1998.

(60) Woon, D. E.; Dunning, T. H., J r. J . Chem. Phys. 1993, 98, 1358. (61) Bergner, A.; Dolg, M.; Kuechle, W.; Stoll, H.; Preuss, H. Mol. Phys. 1993, 80, 1431.

(62) Andrae, D.; Haeussermann, U.; Dolg, M.; Stoll, H.; Preuss, H.

Theor. Chim. Acta 1990, 77, 123.

(63) Stephens, P. J .; Devlin, F. J .; Cabalowski, C. F .; Frisch, M. J

J . Phys. Chem. 1994, 98, 11623.

(64) Becke, A. D. Phys. Rev. A 1988, 38, 3098.

(65) Perdew, J. P. Phys. Rev. A 1986, 33, 8822.

(66) Wong, M. W. Chem. Phys. Lett. 1996, 256, 391

(67) Sheldrick, G. M. SHELX-97: Program for Crystal Structure Determination from Diffraction Data; University of Göttingen: Göttingen, Germany, 1997. metry was constrained to $\mathrm{C}_{\mathrm{s}}$ or $\mathrm{C}_{2 \mathrm{v}}$ point groups throughout the calculations.

trans-RuCl (dppe) $_{2}$. $\mathrm{RuCl}_{2}(\mathrm{dmso})_{4}(0.848 \mathrm{~g}, 1.75 \mathrm{mmol})$ and 1,2-bis(diphenyl phosphino)ethane (dppe, $1.44 \mathrm{~g}, 3.5 \mathrm{mmol}$ ) were suspended in xylene $(70 \mathrm{~mL})$ and put under reflux. Within few minutes a dear yellow solution was obtained which gradually darkened to orange-yellow with the concomitant formation of some dark yellow precipitate. After $7 \mathrm{~h}$ the suspension was cooled to room temperature and then stored at $+4{ }^{\circ} \mathrm{C}$ overnight. The dark yellow solid was collected by filtration, washed with three $15 \mathrm{~mL}$ portions of ether and hexanes each, and then dried in vacuo. A second crop was obtained after concentrating the mother liquor to about $8 \mathrm{~mL}$ and precipitating with ether. Combined yield: $1.485 \mathrm{~g}, 87.6 \%$.

trans- $\left[\mathrm{Cl}(\mathrm{dppm})_{2} \mathrm{RuC}_{3}\left(\mathrm{NMe}_{2}\right) \mathbf{C}_{2} \mathrm{H}_{4} \mathbf{C H}=\mathbf{C H}_{2}\right]^{+}$(4a). To a mixture of solid cis-RuCl${ }_{2}(\mathrm{dppm})_{2}(0.136 \mathrm{~g}, 0.145 \mathrm{mmol})$ and $\mathrm{NaPF}_{6}(0.097 \mathrm{~g}, 0.578 \mathrm{mmol})$ was added excess butadiyne dissolved in $\mathrm{CH}_{2} \mathrm{Cl}_{2}(30 \mathrm{~mL})$. After approximately 30 min the reaction mixture turned green. At this point $\mathrm{NMe}_{2} \mathrm{C}_{3} \mathrm{H}_{5}(100$ $\mu \mathrm{L}, 0.85 \mathrm{mmol}$ ) was added by syringe. The solution was stirred under ambient conditions under occasional IR control. When the intensity of the allenylidene band near $1900 \mathrm{~cm}^{-1}$ remained unchanged (ca. $22 \mathrm{~h}$ ), excess $\mathrm{NaPF}_{6}$ and the $\mathrm{NaCl}$ formed were removed by cannula filtration and the solvent was driven off under reduced pressure. Purification was achieved by column chromatography on basic alumina (eluant $\mathrm{CH}_{2} \mathrm{Cl}_{2} / \mathrm{CH}_{3} \mathrm{CN}$ 12: 1). The first, intensely yellow-green fraction was collected. The oily residue that remained after evaporation of solvents was triturated with ether, and the resulting green powder was dried in vacuo to give $0.087 \mathrm{~g}(0.073 \mathrm{mmol}, 51 \%)$ of 4 a. ${ }^{1} \mathrm{H}$ NMR $\left(\mathrm{CDCl}_{3}\right): \delta 1.35\left(\mathrm{~m}, \mathrm{CH}_{2}\right.$ (butenyl), $\left.2 \mathrm{H}\right), 1.52\left(\mathrm{~m}, \mathrm{CH}_{2}\right.$ (butenyl), $2 \mathrm{H}), 2.02\left(\mathrm{~s}, \mathrm{NCH}_{3}, 3 \mathrm{H}\right), 2.82\left(\mathrm{~s}, \mathrm{NCH}_{3}, 3 \mathrm{H}\right), 4.77$ (dd, trans $\mathrm{HC}=\mathrm{CHH},{ }^{2} \mathrm{H}_{\mathrm{H}-\mathrm{H}}=1.4 \mathrm{~Hz},{ }^{3} \mathrm{H}_{\mathrm{H}} \mathrm{H}=17.0 \mathrm{~Hz}, 1 \mathrm{H}$ ), $4.77\left(\mathrm{~m}, \mathrm{CH}_{2}(\mathrm{dppm}), 2 \mathrm{H}\right), 4.92\left(\mathrm{dd}, \mathrm{cis}-\mathrm{HC}=\mathrm{CHH},{ }^{2} \mathrm{~J} \mathrm{H}-\mathrm{H}^{=}\right.$ $1.4 \mathrm{~Hz}$, 3 $\mathrm{H}-\mathrm{H}=10.2 \mathrm{~Hz}, 1 \mathrm{H}$ ), 5.09 (dquint, $\mathrm{CH}_{2}$ (dppm), J $\mathrm{H}-\mathrm{H}$ $\left.=14.9 \mathrm{~Hz},{ }^{2} \mathrm{P}_{\mathrm{P}-\mathrm{H}}=3 \mathrm{~J}_{\mathrm{P}-\mathrm{H}}=4.4 \mathrm{~Hz}, 2 \mathrm{H}\right), 5.34\left(\mathrm{~m}, \mathrm{HC}=\mathrm{CH}_{2}\right.$, $1 \mathrm{H}), 7.13$ (m, aryl H (dppm), 8H), 7.23 (m, aryl H (dppm), 20H), 7.41 (m, aryl H (dppm), 4H ), 7.53 (m, aryl H (dppm), 8H). ${ }^{13} \mathrm{C}-$ $\left\{{ }^{1} \mathrm{H}\right\} \mathrm{NMR}\left(\mathrm{CDCl}_{3}\right): \delta 28.9\left(\mathrm{CH}_{2}\right.$ (butenyl)), $35.5\left(\mathrm{CH}_{2}\right.$ (bute nyl)), $40.4\left(\mathrm{CH}_{3} \mathrm{~N}\right), 43.2\left(\mathrm{CH}_{3} \mathrm{~N}\right), 48.7$ (vquint, $\mathrm{CH}_{2}$ (dppm), $\left.\mathrm{N}_{\mathrm{P}-\mathrm{C}}=11.1 \mathrm{~Hz}\right), 116.2\left(\mathrm{C}=\mathrm{CH}_{2}\right.$ (butenyl)), 118.7 (C2), 127.9 $\left(\mathrm{m}, \mathrm{m}-\mathrm{C}_{6} \mathrm{H}_{5}, \mathrm{~N}_{\mathrm{P}-\mathrm{C}}=2.3 \mathrm{~Hz}\right), 128.5\left(\mathrm{~m}, \mathrm{~m}-\mathrm{C}_{6} \mathrm{H}_{5}, \mathrm{~N}_{\mathrm{P}-\mathrm{C}}=2.2\right.$ $\mathrm{Hz}$ ), 130.0, $130.7\left(\mathrm{p}-\mathrm{C}_{6} \mathrm{H}_{5}\right), 132.5$ (vquint, ipso- $\mathrm{C}_{6} \mathrm{H}_{5}, \mathrm{~N}_{\mathrm{P}-\mathrm{C}}=$ $11.7 \mathrm{~Hz}), 133.0\left(\mathrm{~m}, \mathrm{o}-\mathrm{C}_{6} \mathrm{H}_{5}, \mathrm{~N}_{\mathrm{p}-\mathrm{C}}=2.9 \mathrm{~Hz}\right), 133.4\left(\mathrm{~m}, \mathrm{o}-\mathrm{C}_{6} \mathrm{H}_{5}\right.$ $\mathrm{N}_{\mathrm{P}-\mathrm{C}}=2.8 \mathrm{~Hz}$ ), 134.1 (vquint, ipso- $\mathrm{C}_{6} \mathrm{H}_{5}, \mathrm{~N}_{\mathrm{P}-\mathrm{C}}=11.2 \mathrm{~Hz}$ ), $135.2\left(\mathrm{C}=\mathrm{CH}_{2}\right.$ (butenyl)), 156.9 (C3), 202.1 (quint, $\mathrm{C} 1$, J $\mathrm{p}-\mathrm{C}=$ $13.9 \mathrm{~Hz}) ;{ }^{31} \mathrm{P}\left\{{ }^{1} \mathrm{H}\right\} \mathrm{NMR}\left(\mathrm{CDCl}_{3}, \mathrm{H}_{3} \mathrm{PO}_{4}(\mathrm{ext})\right): \delta-8.2(\mathrm{~s}, \mathrm{P}$ (dppm)), -143.6 (sept, $\mathrm{PF}_{6}{ }^{-}$, J P-F $\left.=708 \mathrm{~Hz}\right)$. IR $\left(\mathrm{KBr} ; \mathrm{cm}^{-1}\right)$ : $v(\mathrm{CC}) 1995(\mathrm{~s}), v(\mathrm{C}=\mathrm{N}) 1572(\mathrm{~m}) . \mathrm{UV} / \mathrm{vis}\left(\mathrm{CH}_{3} \mathrm{CN} ; \lambda_{\max }, \mathrm{nm}\right.$ $(\log \epsilon)): 209$ (4.94), 229 (4.86), 264 (sh), 384 (4.13), 465 (sh, 2.89), 635 (2.48). Anal. Calcd for $\mathrm{C}_{59} \mathrm{H}_{57} \mathrm{ClF}_{6} \mathrm{NP}_{5} \mathrm{Ru}$ : C,59.78; $\mathrm{H}, 4.84 ; \mathrm{N}, 1.18$. Found: $\mathrm{C}, 59.05 ; \mathrm{H}, 4.82 ; \mathrm{N}, 1.21$.

trans-[Cl(dppe) $\left.{ }_{2} \mathrm{RuC}_{3}\left(\mathrm{NMe}_{2}\right) \mathrm{C}_{2} \mathrm{H}_{4} \mathbf{C H}=\mathrm{CH}_{2}\right]^{+} \mathrm{SbF}_{6}{ }^{-}$(4b). trans-RuCl${ }_{2}$ (dppe) $)_{2}(0.248 \mathrm{~g}, 0.256 \mathrm{mmol})$ and $\mathrm{NaSbF}_{6}(0.290$ $\mathrm{g}, 1.12 \mathrm{mmol}$ ) were suspended in $\mathrm{O}-\mathrm{C}_{6} \mathrm{H}_{4} \mathrm{Cl}_{2}$, and excess butadiyne (ca. $700 \mu \mathrm{L}$ ) was added. The suspension was stirred for $45 \mathrm{~min}$ at room temperature, and $\mathrm{NMe}_{2} \mathrm{C}_{3} \mathrm{H}_{5}(90 \mu \mathrm{L}, 0.76$ $\mathrm{mmol}$ ) was added by syringe. After 3 days a clear orange solution with some white preci pitate (excess $\mathrm{NaSbF}_{6}$ and $\mathrm{NaCl}$ ) had formed, which exhibited an intense IR absorption band at $1983 \mathrm{~cm}^{-1}$. After filtration the solvent was driven off in vacuo and the oily residue was repeatedly washed with $5 \mathrm{~mL}$ portions of hexanes. The orange-red powdery residue was then recrystallized from $\mathrm{CH}_{2} \mathrm{Cl}_{2} /$ hexane to yield orange-red crystals of $\mathbf{4 b} \cdot 3 \mathrm{CH}_{2} \mathrm{Cl}_{2}$. Two more batches were obtained upon further concentration of the mother liquors to give a total yield of 0.335 $\mathrm{g}(83.9 \%)$. ${ }^{1} \mathrm{H}$ NMR $\left(\mathrm{CD}_{2} \mathrm{Cl}_{2}\right): \delta 1.27$ (m, $\mathrm{CH}_{2}$ (butenyl), $\left.2 \mathrm{H}\right)$, 1.46 (m, $\mathrm{CH}_{2}$ (butenyl), 2H), 2.62 (br, $\mathrm{CH}_{2}$ (dppe), 4H), 2.78 (s, $\left.\mathrm{NCH}_{3}, 3 \mathrm{H}\right), 2.92\left(\mathrm{br}, \mathrm{CH}_{2}\right.$ (dppe), 4H), $3.30\left(\mathrm{~s}, \mathrm{NCH}_{3}, 3 \mathrm{H}\right), 5.05$ (dd, trans $\mathrm{HC}=\mathrm{CHH}, 2 \mathrm{~J}_{\mathrm{H}-\mathrm{H}}=1.1 \mathrm{~Hz}$, 3 $\mathrm{J}_{\mathrm{H}-\mathrm{H}}=17.2 \mathrm{~Hz}, 1 \mathrm{H}$ ), $5.11\left(\mathrm{dd}, \mathrm{cis}-\mathrm{HC}=\mathrm{CHH},{ }^{2} \mathrm{~J}_{\mathrm{H}-\mathrm{H}}=1.1 \mathrm{~Hz},{ }^{3} \mathrm{~J}-\mathrm{H}=10.3 \mathrm{~Hz}, 1 \mathrm{H}\right)$, 
$5.33\left(\mathrm{CH}_{2} \mathrm{Cl}_{2}\right), 5.72$ (ddd, $\mathrm{HC}=\mathrm{CH}_{2}, 1 \mathrm{H},{ }^{2} \mathrm{~J}_{\mathrm{H}-\mathrm{H}}=1.1 \mathrm{~Hz},{ }^{3} \mathrm{~J}-\mathrm{H}$ $=10.3,6.2 \mathrm{~Hz}), 6.63(\mathrm{~m}$, aryl H (dppm), 8H ), 7.15 (t, aryl H (dppm), 3 $\left.{ }_{\mathrm{H}-\mathrm{H}}=7.6 \mathrm{~Hz}, 8 \mathrm{H}\right), 7.30\left(\mathrm{t}\right.$, aryl $\mathrm{H}(\mathrm{dppm}), 3_{\mathrm{H}-\mathrm{H}}=$ $7.6 \mathrm{~Hz}, 8 \mathrm{H}), 7.41$ (t, aryl $\left.\mathrm{H}(\mathrm{dppm}),{ }^{3} \mathrm{H}_{-\mathrm{H}}=7.3 \mathrm{~Hz}, 4 \mathrm{H}\right), 7.51$ (t, aryl H (dppm), 尚 $\mathrm{H}-\mathrm{H}=7.3 \mathrm{~Hz}, 4 \mathrm{H}), 7.65$ (br, aryl H (dppm), $8 \mathrm{H}) .{ }^{13} \mathrm{C}\left\{{ }^{1} \mathrm{H}\right\} \mathrm{NMR}\left(\mathrm{CDCl}_{3}\right): \delta 30.2\left(\mathrm{CH}_{2}\right.$ (butenyl)), 30.3 (quint, $\mathrm{CH}_{2}$ (dppe), J p-C $\left.=7.0 \mathrm{~Hz}\right), 36.4\left(\mathrm{CH}_{2}\right.$ (butenyl)), $42.1\left(\mathrm{CH}_{3} \mathrm{~N}\right)$, $44.8\left(\mathrm{CH}_{3} \mathrm{~N}\right), 117.6\left(\mathrm{C}=\mathrm{CH}_{2}\right.$ (butenyl)), 118.8 (quint, $\mathrm{C} 2$, J $\mathrm{p}-\mathrm{C}$ $=1.6 \mathrm{~Hz}$ ), 129.1 (quint, $m-\mathrm{C}_{6} \mathrm{H}_{5}, \mathrm{~N}_{\mathrm{P}-\mathrm{C}}=2.4 \mathrm{~Hz}$ ), 129.3 (quint, $m-\mathrm{C}_{6} \mathrm{H}_{5}, \mathrm{~N}$ p-c $=2.1 \mathrm{~Hz}$ ), 131.2, $132.2\left(\mathrm{p}-\mathrm{C}_{6} \mathrm{H}_{5}\right), 131.6$ (quint, ipso- $\mathrm{C}_{6} \mathrm{H}_{5}, \mathrm{~N}_{\mathrm{p}-\mathrm{C}}=10.6 \mathrm{~Hz}$ ), 132.5 (quint, $\mathrm{o}-\mathrm{C}_{6} \mathrm{H}_{5}, \mathrm{~N}_{\mathrm{p}-\mathrm{C}}=2.2$ $\mathrm{Hz}$ ), 132.8 (quint, ipso- $\mathrm{C}_{6} \mathrm{H}_{5}, \mathrm{~N}_{\mathrm{P}-\mathrm{C}}=11.5 \mathrm{~Hz}$ ), 134.3 (quint, $\left.\mathrm{N}_{\mathrm{P}-\mathrm{C}}=2.8 \mathrm{~Hz}, \mathrm{o}-\mathrm{C}_{6} \mathrm{H}_{5}\right), 134.7\left(\mathrm{C}=\mathrm{CH}_{2}\right.$ (butenyl)), 160.2 (quint, $\mathrm{C} 3$, J $\mathrm{P}-\mathrm{C}=1.2 \mathrm{~Hz}$ ), 189.5 (quint, $\mathrm{Cl}$, J $\mathrm{P}-\mathrm{C}=14.5 \mathrm{~Hz}$ ). ${ }^{31 \mathrm{P}}\left\{{ }^{1} \mathrm{H}\right\}$ NMR (CDCl 3 ): $\delta 46.6$ (s, P (dppe)). IR (KBr; $\left.\mathrm{cm}^{-1}\right): v(\mathrm{CC}) 2005$ (s), $v(\mathrm{C}=\mathrm{N}) 1585(\mathrm{~m})$. UV/vis $\left(\mathrm{CH}_{3} \mathrm{CN} ; \lambda_{\max }, \mathrm{nm}(\log \epsilon)\right): 203$ (4.87), 223 (sh, 4.70), 253 (4.61), 268 (sh, 4.43), 325 (sh, 3.78), 364 (4.12), 415 (sh, 3.32), 688 (1.90). Anal. Calcd for $\mathrm{C}_{61} \mathrm{H}_{61}$ $\mathrm{ClF}_{6} \mathrm{NP}_{4} \mathrm{RuSb} \cdot 3 \mathrm{CH}_{2} \mathrm{Cl}_{2}$ : C, 49.30; $\mathrm{H}, 4.33 ; \mathrm{N}, 0.90$. Found: $\mathrm{C}$, 48.93; $\mathrm{H}, 4,34 ; \mathrm{N}, 1.05$.

trans- $\left[\mathrm{Cl} \text { (depe) }{ }_{2} \mathrm{RuC}_{3}\left(\mathrm{NMe}_{2}\right) \mathrm{C}_{2} \mathrm{H}_{4} \mathrm{CH}=\mathrm{CH}_{2}\right]^{+} \mathbf{P F}_{6}{ }^{-}$(4c). The synthesis was performed in analogy to compound $\mathbf{4 a}$, but starting from cis-RuCl ${ }_{2}$ (depe) ${ }_{2}(0.156 \mathrm{~g}, 0.267 \mathrm{mmol}), \mathrm{NaPF}_{6}$ $(0.178 \mathrm{~g}, 1.06 \mathrm{mmol})$, butadiyne, and NMe allyl (190 $\mu \mathrm{L}, 1.61$ mmol); $\mathrm{CH}_{2} \mathrm{Cl}_{2} / \mathrm{CH}_{3} \mathrm{CN}$ (8:1) was used as the eluant in the chromatographic workup. After removal of the solvent a dark green oil was obtained which solidified after trituration with $\mathrm{Et}_{2} \mathrm{O}$. Yield: $0.078 \mathrm{~g}, 0.094 \mathrm{mmol}, 35 \%$. ${ }^{1} \mathrm{H} \mathrm{NMR}\left(\mathrm{CDCl}_{3}\right): \delta$ $1.12\left(\mathrm{~m}, \mathrm{CH}_{3}\right.$ (depe), 24H), $1.80\left(\mathrm{~m}, \mathrm{CH}_{2}\right.$ (depe), $\left.16 \mathrm{H}\right), 2.05$ (vsext, $\mathrm{CH}_{2}$ (depe), ${ }^{3} \mathrm{P}_{\mathrm{P}-\mathrm{H}}={ }^{3} \mathrm{~J} \mathrm{C}-\mathrm{H}^{2}{ }^{2} \mathrm{~J} \mathrm{C}-\mathrm{H}=7.4 \mathrm{~Hz}, 4 \mathrm{H}$ ), 2.28 (m, $\mathrm{CH}_{2}$ (butenyl), 2H), 2.31 (vsext, $\mathrm{CH}_{2}$ (depe), ${ }^{3} \mathrm{~J}-\mathrm{H}=3 \mathrm{~J} \mathrm{c}-\mathrm{H}$ $\left.={ }^{2} \mathrm{C}_{\mathrm{C}-\mathrm{H}}=7.6 \mathrm{~Hz}, 4 \mathrm{H}\right), 2.51\left(\mathrm{~m}, \mathrm{CH}_{2}\right.$ (butenyl), $\left.2 \mathrm{H}\right), 3.18(\mathrm{~s}$, $\left.\mathrm{NCH}_{3}, 3 \mathrm{H}\right), 3.28\left(\mathrm{~s}, \mathrm{NCH}_{3}, 3 \mathrm{H}\right), 5.01$ (dd, trans-HC=CHH,

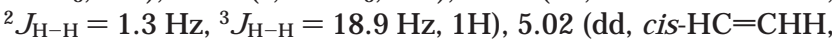
2) $\left.{ }_{\mathrm{H}-\mathrm{H}}=1.3 \mathrm{~Hz}, 3 \mathrm{H}-\mathrm{H}=12.5 \mathrm{~Hz}, 1 \mathrm{H}\right), 5.27\left(\mathrm{~s}, \mathrm{CH}_{2} \mathrm{Cl}_{2}\right), 5.75$ (m, $\mathrm{HC}=\mathrm{CH}_{2}$ (butenyl), $\left.1 \mathrm{H}\right) \cdot{ }^{13} \mathrm{C}\left\{{ }^{1} \mathrm{H}\right\} \mathrm{NMR}\left(\mathrm{CDCl}_{3}\right): \delta$ 9.0, 9.1 $\left(\mathrm{CH}_{3}\right.$ (depe)), $17.10\left(\mathrm{~m},\left(\mathrm{CH}_{2}\right.\right.$ (depe), $\left.\left.\mathrm{N}_{\mathrm{P}-\mathrm{C}}=6.3 \mathrm{~Hz}\right)\right), 19.8(\mathrm{~m}$, $\left(\mathrm{CH}_{2}\right.$ (depe), $\left.\left.\mathrm{N}_{\mathrm{P}-\mathrm{C}}=6.6 \mathrm{~Hz}\right)\right), 20.4\left(\mathrm{~m}, \mathrm{PCH}_{2} \mathrm{CH}_{2} \mathrm{P}, \mathrm{N} \mathrm{P}-\mathrm{C}=11.7\right.$ $\mathrm{Hz}), 30.9\left(\mathrm{CH}_{2}\right.$ (butenyl)), $37.4\left(\mathrm{CH}_{2}\right.$ (butenyl)), $40.7\left(\mathrm{NCH}_{3}\right)$, $44.4\left(\mathrm{NCH}_{3}\right), 116.5\left(\mathrm{HC}=\mathrm{CH}_{2}\right), 117.9(\mathrm{C} 2), 135.3\left(\mathrm{HC}=\mathrm{CH}_{2}\right)$, 155.4 (C3), 211.1 (quint, $\mathrm{Cl}, \mathrm{J}-\mathrm{P}-\mathrm{C}=13.7 \mathrm{~Hz}$ ). ${ }^{31} \mathrm{P}\left\{{ }^{1} \mathrm{H}\right\} \mathrm{NMR}$ $\left(\mathrm{CDCl}_{3}\right): \delta 47.58$ (s, P (depe)), -144.0 (sept, $\mathrm{PF}_{6}^{-} \mathrm{J}_{\mathrm{P}-\mathrm{F}}=707$ Hz). IR (KBr; cm ${ }^{-1}$ ): v(CC) 1979 (vs), v(C=N) 1564 (s). UV/vis $\left(\mathrm{CH}_{3} \mathrm{CN} ; \lambda_{\max }, \mathrm{nm}(\log \epsilon)\right): 215$ (4.27), 287 (3.06), 400 (4.24), 491 (sh, 2.55), 626 (2.58). Anal. Calcd for $\mathrm{C}_{29} \mathrm{H}_{61} \mathrm{ClF}_{6} \mathrm{NP}_{5} \mathrm{Ru}$. $0.5 \mathrm{CH}_{2} \mathrm{Cl}_{2}$ : C, 40.65; $\mathrm{H}, 7.17 ; \mathrm{N}, 1.61$. Found: $\mathrm{C}, 40.84 ; \mathrm{H}$, 6,$94 ; \mathrm{N}, 1.59$.

trans-[Cl(dppm) $\left.)_{2} \mathrm{RuC}_{3}\left(\mathrm{NC}_{5} \mathrm{H}_{10}\right) \mathrm{C}_{2} \mathrm{H}_{4} \mathrm{CH}=\mathrm{CH}_{2}\right]^{+} \mathrm{SbF}_{6}$ (4d). This compound was prepared as described for $\mathbf{4 a}$. With $0.175 \mathrm{~g}(0.186 \mathrm{mmol})$ of cis-RuCl${ }_{2}(\mathrm{dppm})_{2}, 0.186 \mathrm{~g}$ of $\mathrm{NaSbF}_{6}$ $(0.72 \mathrm{mmol})$, and $112 \mathrm{mg}$ of allylpiperidine $(0.89 \mathrm{mmol})$ as the starting materials, $0.152 \mathrm{~g}(0.116 \mathrm{mmol}, 62.4 \%)$ of $\mathbf{4 d}$ was obtained as a yellow-green powder after chromatographic workup on silica gel $\left(\mathrm{CH}_{2} \mathrm{Cl}_{2} / \mathrm{CH}_{3} \mathrm{CN}\right.$ (10:1) v/v) as eluant). ${ }^{1} \mathrm{H}$ NMR $\left(\mathrm{CD}_{3} \mathrm{CN}\right.$ ): $\delta 1.0$ (quint (br), $\mathrm{CH}_{2}$ (pip), $2 \mathrm{H}, \mathrm{J}_{\mathrm{H}-\mathrm{H}}=4.9$ $\mathrm{Hz}$ ), 1.43-1.52 (m, $\mathrm{CH}_{2}$ (pip) and $\mathrm{CH}_{2}$ (butenyl), 8H), 2.70 (dd, $\left.\mathrm{NCH}_{2}, 2 \mathrm{H}, \mathrm{J}_{\mathrm{H}-\mathrm{H}}=6.3,5.9 \mathrm{~Hz}\right), 3.21\left(\mathrm{~m}, \mathrm{br} \mathrm{NCH} \mathrm{NCH}_{2}, 2 \mathrm{H}\right), 4.85$ (dquint, $\mathrm{CH}_{2}$ (dppm), J $\mathrm{H}-\mathrm{H}=15.1 \mathrm{~Hz},{ }^{2} \mathrm{~J}_{\mathrm{P}-\mathrm{H}}=3 \mathrm{~J}_{\mathrm{P}-\mathrm{H}}=4.3 \mathrm{~Hz}$, $2 \mathrm{H}$ ), 4.86 (ddt, trans $\mathrm{HC}=\mathrm{CHH},{ }^{2} \mathrm{~J} \mathrm{H}-\mathrm{H}^{2}=1.7 \mathrm{~Hz},{ }^{3} \mathrm{~J} \mathrm{H}-\mathrm{H}=16.9$ $\left.\mathrm{Hz},{ }^{4} \mathrm{H}-\mathrm{H}=0.8 \mathrm{~Hz}, 1 \mathrm{H}\right), 4.96\left(\mathrm{ddd}\right.$, cis- $\mathrm{HC}=\mathrm{CHH},{ }^{2} \mathrm{~J} \mathrm{H}-\mathrm{H}^{-}$ $1.7 \mathrm{~Hz}$, 3 ${ }_{\mathrm{H}-\mathrm{H}}=10.2 \mathrm{~Hz}, 4 \mathrm{~J}_{\mathrm{H}-\mathrm{H}}=0.8 \mathrm{~Hz}, 1 \mathrm{H}$ ), 5.22 (dquint, $\mathrm{CH}_{2}(\mathrm{dppm}), \mathrm{J} \mathrm{H}-\mathrm{H}=15.1 \mathrm{~Hz},{ }^{2} \mathrm{~J} \mathrm{P}-\mathrm{H}=3 \mathrm{~J}_{\mathrm{P}-\mathrm{H}}=4.6 \mathrm{~Hz}, 2 \mathrm{H}$ ), $5.39\left(\mathrm{~m}, \mathrm{HC}=\mathrm{CH}_{2}, 1 \mathrm{H}\right), 7.21(\mathrm{~m}$, aryl $\mathrm{H}(\mathrm{dppm}), 8 \mathrm{H}), 7.31-$ 7.47 (m, aryl H (dppm), 24H), 7.57 (m, aryl H (dppm), 8H). ${ }^{13} \mathrm{C}\left\{{ }^{1} \mathrm{H}\right\} \operatorname{NMR}\left(\mathrm{CD}_{3} \mathrm{CN}\right): \delta 23.6,27.2,27.4\left(\mathrm{CH}_{2}\right.$ (pip), 31.5, $36.4\left(\mathrm{CH}_{2}\right.$ (butenyl)), 48.9 (quint, $\mathrm{CH}_{2}$ (dppm), $\mathrm{N}_{\mathrm{P}-\mathrm{C}}=11.84$ $\mathrm{Hz}), 50.7,51.7\left(\mathrm{CH}_{2} \mathrm{~N}\right.$ (pip), $116.8\left(\mathrm{C}=\mathrm{CH}_{2}\right.$ (butenyl)), 119.4 (quint, $\mathrm{C} 2$, J $\mathrm{p}-\mathrm{C}=1.57 \mathrm{~Hz}$ ), 128.9, 129.5 (quint, $\mathrm{m}-\mathrm{C}_{6} \mathrm{H}_{5}, \mathrm{~N}_{\mathrm{P}-\mathrm{C}}$ $=2.6 \mathrm{~Hz}$ ), $131.1,131.6\left(\mathrm{~s}, \mathrm{p}-\mathrm{C}_{6} \mathrm{H}_{5}\right), 133.9$ (quint, $\mathrm{o}-\mathrm{C}_{6} \mathrm{H}_{5}, \mathrm{~N}_{\mathrm{p}-\mathrm{C}}$ $=3.1 \mathrm{~Hz}$ ), 134.1 (quint, o- $\mathrm{C}_{6} \mathrm{H}_{5}, \mathrm{~N}_{\mathrm{p}-\mathrm{C}}=3.2 \mathrm{~Hz}$ ), 135.6 (quint, ipso- $\left.\mathrm{C}_{6} \mathrm{H}_{5}, \mathrm{~N}_{\mathrm{P}-\mathrm{C}}=11.3 \mathrm{~Hz}\right), 136.6\left(\mathrm{CH}=\mathrm{CH}_{2}\right.$ (butenyl)), 156.2 (quint, $\mathrm{C} 3$, J $\mathrm{p}-\mathrm{C}=1.1 \mathrm{~Hz}$ ), 202.2 (quint, $\mathrm{C} 1$, J $\mathrm{p}-\mathrm{C}=13.9 \mathrm{~Hz}$ ). ${ }^{31} \mathrm{P}\left\{{ }^{1} \mathrm{H}\right\} \mathrm{NMR}\left(\mathrm{CDCl}_{3}, \mathrm{H}_{3} \mathrm{PO}_{4}(\mathrm{ext})\right): \delta-8.1$ (s, $\left.\mathrm{P}(\mathrm{dppm})\right)$. IR $\left(\mathrm{KBr} ; \mathrm{cm}^{-1}\right): v(\mathrm{CC}) 1995$ (vs), $v(\mathrm{C}=\mathrm{N}) 1553$ (s). UV/vis $\left(\mathrm{CH}_{3-}\right.$ $\left.\mathrm{CN} ; \lambda_{\max }, \mathrm{nm}(\log \epsilon)\right): 211$ (4.86), 227 (sh), 4.81), 266 (4.62), 391 (4.26), 435 (sh, 3.18), 654 (2.15). Anal. Calcd for $\mathrm{C}_{62} \mathrm{H}_{61-}$ $\mathrm{CIF}_{6} \mathrm{NP}_{4} \mathrm{RuSb}$ : C, 56.57; $\mathrm{H}, 4.67 ; \mathrm{N}, 1.06$. Found: $\mathrm{C}, 57.04$; $\mathrm{H}, 4.62 ; \mathrm{N}, 1.07$.

trans-[Cl(dppm) ${ }_{2} \mathrm{RuC}_{3}\left(\mathrm{NMe}_{2}\right) \mathrm{CH}_{2} \mathrm{CH}\left(\mathrm{CH}_{2} \mathrm{NMe}_{2}\right)(\mathrm{CH}=$ $\left.\left.\mathbf{C H}_{2}\right)\right]^{+}$SbF $_{6}{ }^{-}$(4e). cis-RuCl $(\mathrm{dppm})_{2}(0.181 \mathrm{~g}, 0.191 \mathrm{mmol})$ and $\mathrm{NaSbF}_{6}(0.199 \mathrm{~g}, 0.77 \mathrm{mmol})$ were suspended in o-dichlorobenzene, and excess $\mathrm{HC}_{4} \mathrm{H}$ was added. After the mixture was stirred for $45 \mathrm{~min}$, the solution color had changed to apple green. At this point $0.681 \mathrm{~g}(85 \mu \mathrm{L}, 0.48 \mathrm{mmol})$ of 1,4-bis(dimethylamino)but-2-ene was added by syringe. The reaction was stopped after the initial I R band at $2024 \mathrm{~cm}^{-1}$ of the simple adduct had totally disappeared and the much more intense absorption of the $C_{3}$ unit of the rearranged product at 1991 $\mathrm{cm}^{-1}$ remained unchanged (2 days). After filtration, the solvent was distilled off in vacuo. The tarry residue was vigorously stirred with ether $(3 \times 15 \mathrm{~mL})$ and hexanes $(2 \times 10 \mathrm{~mL})$ and then dried in vacuo to give the pure product as an orange yell ow powder. Yield: $0.234 \mathrm{~g}, 92 \%$. ${ }^{1} \mathrm{H} \mathrm{NMR}\left(\mathrm{CD}_{2} \mathrm{Cl}_{2}\right): \delta 1.27$ (dd $(b r),{ }^{2} \mathrm{~J}-\mathrm{H}=21.1$, 3 $\left.\mathrm{J}_{\mathrm{H}-\mathrm{H}}=12.3 \mathrm{~Hz}, 1 \mathrm{H}\right), 1.95\left(\mathrm{~m}, \mathrm{CH}_{2}\right.$, $4 \mathrm{H}), 2.09(\mathrm{~s}, 3 \mathrm{H}, \mathrm{NMe}), 2.17\left(\mathrm{~s}, 6 \mathrm{H}, \mathrm{NMe}_{2}\right), 2.94(\mathrm{~s}, \mathrm{NMe}, 3 \mathrm{H})$, $3.21(\mathrm{~m}, \mathrm{CH}, 1 \mathrm{H}), 4.76\left(\mathrm{dd}\right.$, trans $\mathrm{HC}=\mathrm{CHH},{ }^{2} \mathrm{H}_{-\mathrm{H}}=2.1 \mathrm{~Hz}$, 3) $\mathrm{H}-\mathrm{H}=16.5 \mathrm{~Hz}, 1 \mathrm{H}), 4.86$ (dquint, $\mathrm{CH}_{2}(\mathrm{dppm}), \mathrm{J} \mathrm{H-H}=14.9$ $\left.\mathrm{Hz},{ }^{2} \mathrm{~J}_{\mathrm{P}-\mathrm{H}}={ }^{3} \mathrm{~J} \mathrm{P}-\mathrm{H}=4.4 \mathrm{~Hz}, 2 \mathrm{H}\right), 4.94\left(\mathrm{dd}, \mathrm{cis}-\mathrm{HC}=\mathrm{CHH},{ }^{2} \mathrm{~J} \mathrm{H}-\mathrm{H}\right.$ $=2.1 \mathrm{~Hz}$, 3 $\left.\mathrm{H}-\mathrm{H}_{\mathrm{H}}=10.2 \mathrm{~Hz}, 1 \mathrm{H}\right), 5.04\left(\mathrm{~m}, \mathrm{HC}=\mathrm{CH}_{2}, 1 \mathrm{H}\right), 5.23$ (dquint, $\mathrm{CH}_{2}$ (dppm), J H-H $=14.9 \mathrm{~Hz},{ }^{2} \mathrm{~J}-\mathrm{H}=3 \mathrm{~J}-\mathrm{H}=4.6 \mathrm{~Hz}$ 2H) $7.23\left(\mathrm{~m}, 7.21\right.$ (t, aryl H (dppm), $\left.{ }^{3} \mathrm{H}_{\mathrm{H}} \mathrm{H}=7.3 \mathrm{~Hz}, 8 \mathrm{H}\right), 7.39$ (m, aryl H (dppm), 18H), 7.50 (m, aryl H (dppm), 6H), 7.63 (m, aryl $\mathrm{H}(\mathrm{dppm}), 8 \mathrm{H}) \cdot{ }^{13} \mathrm{C}\left\{{ }^{1} \mathrm{H}\right\} \mathrm{NMR}\left(\mathrm{CD}_{2} \mathrm{Cl}_{2}\right): \delta 39.8\left(\mathrm{CH}_{2}\right)$, $40.6(\mathrm{CH}), 40.8,43.3\left(\mathrm{NCH}_{3}\right), 45.7\left(\mathrm{~N}\left(\mathrm{CH}_{3}\right)_{2}\right), 48.1$ (quint, $\mathrm{CH}_{2}$ $\left.(\mathrm{dppm}), \mathrm{N}_{\mathrm{p}-\mathrm{C}}=11.2 \mathrm{~Hz}\right), 63.5\left(\mathrm{CH}_{2} \mathrm{~N}\right), 116.7\left(\mathrm{C}=\mathrm{CH}_{2-}\right.$ (butenyl)), $120.8(\mathrm{t}, \mathrm{C} 2, \mathrm{~J} \mathrm{p}-\mathrm{C}=1.1 \mathrm{~Hz}), 127.9\left(\mathrm{t}, \mathrm{m}-\mathrm{C}_{6} \mathrm{H}_{5}, \mathrm{~J} \mathrm{p}-\mathrm{C}\right.$ $=4.7 \mathrm{~Hz}$ ), $128.0\left(\mathrm{t}, \mathrm{m}-\mathrm{C}_{6} \mathrm{H}_{5}, \mathrm{~J} \mathrm{p}-\mathrm{C}=5.3 \mathrm{~Hz}\right), 128.6\left(\mathrm{t}, \mathrm{m}-\mathrm{C}_{6} \mathrm{H}_{5}\right.$, $\left.\mathrm{J}_{\mathrm{P}-\mathrm{C}}=4.2 \mathrm{~Hz}\right), 128.71\left(\mathrm{t}, \mathrm{m}-\mathrm{C}_{6} \mathrm{H}_{5}, \mathrm{~J} \mathrm{P}-\mathrm{C}=4.7 \mathrm{~Hz}\right), 130.1,130.3$, 130.7, $130.9\left(\mathrm{p}-\mathrm{C}_{6} \mathrm{H}_{5}\right), 132.4\left(\mathrm{~m}, \mathrm{ipso}-\mathrm{C}_{6} \mathrm{H}_{5}\right), 132.8,133.1$ (t, $\left.\mathrm{o}^{-\mathrm{C}_{6}} \mathrm{H}_{5}, \mathrm{~J} \mathrm{p}-\mathrm{C}=5.5 \mathrm{~Hz}\right), 133.3\left(\mathrm{t}, \mathrm{o}-\mathrm{C}_{6} \mathrm{H}_{5}, \mathrm{~J} \mathrm{p}-\mathrm{C}=6.3 \mathrm{~Hz}\right), 133.5$ $\left(\mathrm{t}, \mathrm{o}-\mathrm{C}_{6} \mathrm{H}_{5}, \mathrm{~J} \mathrm{p}-\mathrm{C}=5.8 \mathrm{~Hz}\right), 134.2,134.8\left(\mathrm{~m}, \mathrm{ipso}-\mathrm{C}_{6} \mathrm{H}_{5}, \mathrm{~J}\right.$ p-C $=$ $11.3 \mathrm{~Hz}), 137.2\left(\mathrm{CH}=\mathrm{CH}_{2}\right.$ (butenyl)), $156.7(\mathrm{br}, \mathrm{C} 3), 202.3$ (quint, $\mathrm{Cl}$, J $\left.{ }_{\mathrm{P}-\mathrm{C}}=15.5 \mathrm{~Hz}\right) .{ }^{31} \mathrm{P}\left\{{ }^{1} \mathrm{H}\right\} \mathrm{NMR}\left(\mathrm{CD}_{2} \mathrm{Cl}_{2}\right): \delta-7.8$ (AA'BB' spin system, P (dppm)). IR (KBr; cm $\left.{ }^{-1}\right): v(C C) 1985$ (vs), $v(\mathrm{C}=\mathrm{N}) 1582(\mathrm{~m})$. UV/vis $\left(\mathrm{CH}_{3} \mathrm{CN} ; \lambda_{\max }, \mathrm{nm}(\log \epsilon)\right): 217$ (4.74), 228 (sh, 4.73), 265 (4.58), 325 (sh, 3.69), 388 (4.19), 465 (sh, 3.05). Anal. Calcd for $\mathrm{C}_{62} \mathrm{H}_{64} \mathrm{ClF}_{6} \mathrm{~N}_{2} \mathrm{P}_{4} \mathrm{RuSb}: \mathrm{C}, 55.85 ; \mathrm{H}$, 4.84; N, 2.10. Found: C, 55.25; $\mathrm{H}, 4.68 ; \mathrm{N}, 2.14$

trans-[CIRu(dppm) ${ }_{2} \mathrm{C} \equiv \mathrm{CC}\left(\mathrm{N} \mathrm{Me}_{2} \mathrm{CH}_{2} \mathrm{C} \equiv \mathrm{CEt}\right)=$ $\left.\mathbf{C H}_{\mathbf{2}}\right]^{+} \mathbf{P F}_{\mathbf{6}}{ }^{-}$(3f). Solid cis-RuCl${ }_{2}(\mathrm{dppm})_{2}(0.220 \mathrm{~g}, 0.234 \mathrm{mmol})$ and $\mathrm{NaSbF}_{6}(0.242 \mathrm{~g}, 0.93 \mathrm{mmol})$ were suspended in a solution of excess butadiyne in $\mathrm{CH}_{2} \mathrm{Cl}_{2}(30 \mathrm{~mL}$ ). Within the next 40 min a color change from yellow to intense green was observed. The suspension was then cooled to $+4{ }^{\circ} \mathrm{C}$, and 1-(dimethylamino)pent-2-yne (250 $\mu \mathrm{L}, 0.202 \mathrm{~g}, 1.81 \mathrm{mmol}$ ) was added. The solution was stirred for 4 days at this temperature with occasional IR monitoring. Then it was filtered via a papertipped cannula and the solvent removed in vacuo. The oily residue was triturated with ether $(2 \times 15 \mathrm{~mL})$, and the residual powdery solid was dried in vacuo. This crude product was then chromatographed on a silica column maintained at $-3^{\circ} \mathrm{C} . \mathrm{CH}_{2^{-}}$ $\mathrm{Cl}_{2} / \mathrm{CH}_{3} \mathrm{CN}(25: 2 \mathrm{v} / \mathrm{v})$ eluted a bluish green band, which was collected. (A second olive green fraction provided a complex mixture of several compounds and was discarded.) The solvents were driven off in vacuo, and the remaining solid was washed with small portions of ether and dried to give $0.082 \mathrm{~g}$ (27\%) of pure 3f. ${ }^{1} \mathrm{H} \mathrm{NMR}\left(\mathrm{CDCl}_{3}\right): \delta 1.12\left(\mathrm{t}, \mathrm{CH}_{2} \mathrm{CH}_{3},{ }^{3} \mathrm{~J} \mathrm{H}-\mathrm{H}\right.$ $=7.5 \mathrm{~Hz}, 3 \mathrm{H}$ ), 2.22 (qt, $\left.\mathrm{CH}_{2} \mathrm{CH}_{3}, 3\right)_{\mathrm{H}-\mathrm{H}}=7.5 \mathrm{~Hz}, 5 \mathrm{~J}_{\mathrm{H}-\mathrm{H}}=2.2$ $\mathrm{Hz}, 2 \mathrm{H}), 2.28\left(\mathrm{~s}, 6 \mathrm{H}, \mathrm{NMe}_{2}\right), 2.78\left(\mathrm{t}, \mathrm{CH}_{2} \mathrm{~N}, 5 \mathrm{~J} \mathrm{H}-\mathrm{H}=2.2 \mathrm{~Hz}\right.$, $2 \mathrm{H}), 3.92\left(\mathrm{~d}, \mathrm{C}=\mathrm{CHH},{ }^{2} \mathrm{~J}-\mathrm{H}=3.1 \mathrm{~Hz}, 1 \mathrm{H}\right), 4.74(\mathrm{~d}, \mathrm{C}=\mathrm{CHH}$, 2) $\left.{ }_{\mathrm{H}-\mathrm{H}}=3.1 \mathrm{~Hz}, 1 \mathrm{H}\right), 4.73$ (dquint, $\mathrm{CH}_{2}(\mathrm{dppm})$, J $\mathrm{H}-\mathrm{H}=14.5$ $\mathrm{Hz},{ }^{2} \mathrm{~J}_{\mathrm{P}-\mathrm{H}}={ }^{4} \mathrm{~J}_{\mathrm{p}^{\prime}-\mathrm{H}}=4.6 \mathrm{~Hz}, 2 \mathrm{H}$ ), 4.96 (dquint, $\mathrm{CH}_{2}$ (dppm), 
$\left.\mathrm{J}_{\mathrm{H}-\mathrm{H}}=14.5 \mathrm{~Hz},{ }^{2} \mathrm{~J}_{\mathrm{P}-\mathrm{H}}={ }^{4} \mathrm{~J}_{\mathrm{P}^{\prime}-\mathrm{H}}=4.7 \mathrm{~Hz}, 2 \mathrm{H}\right), 7.09$ (t, aryl $\mathrm{H}$

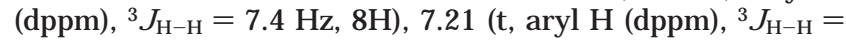
$7.4 \mathrm{~Hz}, 10 \mathrm{H}), 7.27-7.33$ (m, aryl H (dppm), 14H), 7.39 (m, aryl $\mathrm{H}(\mathrm{dppm}), 8 \mathrm{H}) .{ }^{13} \mathrm{C}\left\{{ }^{1} \mathrm{H}\right\} \mathrm{NMR}\left(\mathrm{CDCl}_{3}\right): \delta 12.5\left(\mathrm{CH}_{2} \mathrm{CH}_{3}\right), 13.3$ $\left(\mathrm{CH}_{2} \mathrm{CH}_{3}\right), 49.5\left(\mathrm{~N}\left(\mathrm{CH}_{3}\right)_{2}\right), 49.8$ (quint, $\mathrm{CH}_{2}$ (dppm), $\mathrm{N}_{\mathrm{P}-\mathrm{C}}=$ $10.8 \mathrm{~Hz}), 54.7(\mathrm{C} 3), 67.79\left(\mathrm{NCH}_{2}\right), 67.9,94.3(\mathrm{C} \equiv \mathrm{C}), 98.5(\mathrm{br}$, $\mathrm{C} 2$ ), $106.8\left(\mathrm{C}=\mathrm{CH}_{2}\right), 127.7,128.4$ (quint, $\mathrm{m}-\mathrm{C}_{6} \mathrm{H}_{5}, \mathrm{~N} \mathrm{p}_{-\mathrm{C}}=2.2$ $\mathrm{Hz}), 129.8,130.1\left(\mathrm{p}-\mathrm{C}_{6} \mathrm{H}_{5}\right), 133.8$ (quint, o- $\mathrm{C}_{6} \mathrm{H}_{5}, \mathrm{~N}-\mathrm{c}=3.0$ $\mathrm{Hz}$ ), 132.9 (quint, ipso- $\mathrm{C}_{6} \mathrm{H}_{5}, \mathrm{~N}_{\mathrm{P}-\mathrm{C}}=11.2 \mathrm{~Hz}$ ), 133.6 (quint, $\mathrm{o}-\mathrm{C}_{6} \mathrm{H}_{5}, \mathrm{~N}_{\mathrm{P}-\mathrm{C}}=2.8 \mathrm{~Hz}$ ), 135.28 (quint, ipso- $\mathrm{C}_{6} \mathrm{H}_{5}, \mathrm{~N}_{\mathrm{p}-\mathrm{C}}=11.1$ $\mathrm{Hz}$ ), 148.5 (quint, $\mathrm{C} 1, \mathrm{~J}-\mathrm{P}-\mathrm{C}=13.2 \mathrm{~Hz}) .{ }^{31} \mathrm{P}\left\{{ }^{1} \mathrm{H}\right\} \mathrm{NMR}(101.3$ $\mathrm{MHz}): \delta-5.8(\mathrm{~s}, \mathrm{P}(\mathrm{dppm}))$. IR ( $\left.\mathrm{KBr} ; \mathrm{cm}^{-1}\right): v(\mathrm{C} \equiv \mathrm{C}) 2033(\mathrm{~m})$, $v(\mathrm{C}=\mathrm{C}=\mathrm{C}) 1996(\mathrm{~m}), 1922(\mathrm{w}), v(\mathrm{C}=\mathrm{C}) 1603(\mathrm{w}) . \mathrm{UV} / \mathrm{vis}\left(\mathrm{CH}_{2^{-}}\right.$ $\left.\mathrm{Cl}_{2} ; \lambda_{\max }, \mathrm{nm}(\log \epsilon)\right): 266$ (4.54), 319 (3.89), 640 (3.12). Anal. Calcd for $\mathrm{C}_{61} \mathrm{H}_{59} \mathrm{ClF}_{6} \mathrm{NP}_{4} \mathrm{RuSb}$ : C, 56.26; $\mathrm{H}, 4.57 ; \mathrm{N}, 1.08$. Found: C, 55.89; $\mathrm{H}, 4.52 ; \mathrm{N}, 1.07$.

trans-[CI (dppm $)_{2} \mathrm{RuC}_{3}\left(\mathrm{NMe}_{2}\right) \mathrm{CH}_{2} \mathrm{C}\left(\mathrm{C}_{2} \mathrm{H}_{5}\right)=\mathrm{C}=$ $\mathbf{C H}_{2}{ }^{+} \mathbf{S b F}_{6}{ }^{-}$(4f). Solid cis-RuCl $2(\mathrm{dppm})_{2}(0.250 \mathrm{~g}, 0.266 \mathrm{mmol})$ and $\mathrm{NaSbF}_{6}(0.258 \mathrm{~g}, 1.0 \mathrm{mmol})$ were suspended in odichlorobenzene $(50 \mathrm{~mL})$ to which excess butadiyne had been added. After the suspension had taken on a green coloration, $110 \mu \mathrm{L}(0.089 \mathrm{~g}, 0.80 \mathrm{mmol})$ of 1-(dimethylamino)-2-pentyne was added by syringe. After $23 \mathrm{~h}$ of stirring under ambient conditions the pale green solution showed an IR band at 2032 $\mathrm{cm}^{-1}$ indicative of the formation of the primary adduct 3 . The reaction vessel was immersed in an oil bath maintained at 65 ${ }^{\circ} \mathrm{C}$, and the progress of the rearrangement was monitored by IR. This process was accompanied by a col or change to intense yellow-green and the formation of a much more intense absorption at $1996 \mathrm{~cm}^{-1}$ at the expense of the $2032 \mathrm{~cm}^{-1}$ band. After $23 \mathrm{~h}$ excess $\mathrm{NaSbF}_{6}$ and $\mathrm{NaCl}$ were filtered off and the solvent was removed by vacuum distillation. The slightly tarry residue was vigorously stirred with $10 \mathrm{~mL}$ portions of ether (three times), and the resulting brownish green microcrystalline solid was dried in vacuo to give $0.306 \mathrm{~g}(0.240 \mathrm{mmol}, 90 \%)$ of pure 4f. ${ }^{1} \mathrm{H} N M R\left(\mathrm{CDCl}_{3}\right): \delta 1.09\left(\mathrm{t}, \mathrm{CH}_{3}, 3 \mathrm{H}\right), 1.80\left(\mathrm{~m}, \mathrm{CH}_{2}\right.$, $2 \mathrm{H}), 2.21\left(\mathrm{~s}, \mathrm{NCH}_{3}, 3 \mathrm{H}\right), 2.31\left(\mathrm{~m}, \mathrm{CH}_{2}, 2 \mathrm{H}\right), 2.96\left(\mathrm{~s}, \mathrm{NCH}_{3}\right.$, $3 \mathrm{H}), 4.81,4.83\left(\mathrm{~d},=\mathrm{CHH},{ }^{2} \mathrm{~J}_{\mathrm{H}}=3.7 \mathrm{~Hz}, 1 \mathrm{H}\right), 5.18$ (dquint, $\left.\mathrm{CH}_{2}(\mathrm{dppm}), \mathrm{J} \mathrm{H}-\mathrm{H}^{2}=15.2 \mathrm{~Hz},{ }^{2} \mathrm{~J}_{\mathrm{P}-\mathrm{H}}={ }^{3} \mathrm{~J}_{\mathrm{P}-\mathrm{H}}=4.3 \mathrm{~Hz}, 2 \mathrm{H}\right)$, 5.36 (dquint, $\mathrm{CH}_{2}$ (dppm), J $\mathrm{H}_{-\mathrm{H}}=15.2 \mathrm{~Hz}, \mathrm{~J}_{\mathrm{p}-\mathrm{H}}=3 \mathrm{~J}_{\mathrm{p}-\mathrm{H}}=$ $4.7 \mathrm{~Hz}, 2 \mathrm{H}), 7.37\left(\mathrm{t}\right.$, aryl $\left.\mathrm{H}(\mathrm{dppm}),{ }^{3} \mathrm{~J}-\mathrm{H}^{2}=7.4 \mathrm{~Hz}, 8 \mathrm{H}\right), 7.48$ (m, aryl H (dppm), 12H), 7.59 (m, aryl H (dppm), 12H), 7.78 (m, aryl $\mathrm{H}(\mathrm{dppm}), 8 \mathrm{H}),{ }^{13} \mathrm{C}\left\{{ }^{1} \mathrm{H}\right\} \mathrm{NMR}\left(\mathrm{CD}_{2} \mathrm{Cl}_{2}\right): \delta 11.7\left(\mathrm{CH}_{3}-\right.$ (Et), $25.2\left(\mathrm{CH}_{2}(\mathrm{Et})\right), 40.4\left(\mathrm{CH}_{2}\right.$ (allenyl)), 40.6, $43.0\left(\mathrm{CH}_{3} \mathrm{~N}\right)$, 48.5 (vquint, $\mathrm{CH}_{2}$ (dppm), $\left.\mathrm{N}_{\mathrm{P}-\mathrm{C}}=11.3 \mathrm{~Hz}\right), 79.85\left(\mathrm{C}=\mathrm{CH}_{2}\right.$, allenyl), 100.0 ( $\mathrm{EtC}=\mathrm{C}$, allenyl), 121.9 (quint, $\mathrm{C} 2, \mathrm{~J} \mathrm{p}-\mathrm{C}=1.8$ $\mathrm{Hz}$ ), 128.3, 128.8 (quint, $\mathrm{m}-\mathrm{C}_{6} \mathrm{H}_{5}, \mathrm{~N}_{\mathrm{p}-\mathrm{C}}=2.4 \mathrm{~Hz}$ ), 130.5, 130.9 $\left(\mathrm{p}-\mathrm{C}_{6} \mathrm{H}_{5}\right.$ ), 133.0 (quint, ipso- $\mathrm{C}_{6} \mathrm{H}_{5}, \mathrm{~N}_{\mathrm{p}-\mathrm{C}}=10.8 \mathrm{~Hz}$ ), 133.2, 133.6 (quint, o- $\mathrm{C}_{6} \mathrm{H}_{5}, \mathrm{~N}_{\mathrm{P}-\mathrm{C}}=3.0 \mathrm{~Hz}$ ), 134.3 (quint, ipso- $\mathrm{C}_{6} \mathrm{H}_{5}, \mathrm{~N}_{\mathrm{P}-\mathrm{C}}$ $=11.2 \mathrm{~Hz}$ ), 153.7 (quint, $\mathrm{C} 3, \mathrm{~J} \mathrm{p}-\mathrm{C}=1.1 \mathrm{~Hz}$ ), $204.3(\mathrm{C}=\mathrm{C}=\mathrm{C}$, allenyl), 207.0 (quint, $\mathrm{C} 1, \mathrm{~J}_{\mathrm{P}-\mathrm{C}}=13.7 \mathrm{~Hz}$ ). ${ }^{13} \mathrm{C}$ ( $\mathrm{H}$ coupled) NMR: $\delta 204.3$ (vquint, ${ }^{3} \mathrm{CH}=4.5 \mathrm{~Hz}$ ), $78.9\left(\mathrm{C}=\mathrm{CH}_{2}\right.$, allenyl, $\left.\mathrm{J}_{\mathrm{C}-\mathrm{H}}=167.6 \mathrm{~Hz}\right), 48.5$ (tquint, J $\left.\mathrm{C}-\mathrm{H}=136.3 \mathrm{~Hz}\right), 43.0\left(\mathrm{NCH}_{3}\right.$, $\left.\mathrm{J}_{\mathrm{C}-\mathrm{H}}=141.5 \mathrm{~Hz}\right), 40.6\left(\mathrm{NCH}_{3}, \mathrm{~J}_{\mathrm{C}-\mathrm{H}}=141.2 \mathrm{~Hz}\right), 25.2\left(\mathrm{CH}_{2}, \mathrm{t}\right.$, $\mathrm{br}, \mathrm{J} \mathrm{J}-\mathrm{H}=128.1 \mathrm{~Hz}), 11.7\left(\mathrm{CH}_{3}\right.$, tquart, J $\mathrm{C}-\mathrm{H}=126.6 \mathrm{~Hz},{ }^{3} \mathrm{~J}-\mathrm{H}$ $=4.2 \mathrm{~Hz}) .{ }^{31} \mathrm{P}\left\{{ }^{1} \mathrm{H}\right\} \mathrm{NMR}\left(\mathrm{CD}_{3} \mathrm{CN}\right): \delta-8.0(\mathrm{~s}, \mathrm{P}(\mathrm{dppm}))$. IR (KBr; cm $\left.{ }^{-1}\right): v(\mathrm{CC}) 1995(\mathrm{~s}), 1920(\mathrm{~m}), v(\mathrm{C}=\mathrm{N}) 1572(\mathrm{~m}) . \mathrm{UV} /$ vis $\left(\mathrm{CH}_{3} \mathrm{CN} ; \lambda_{\max }, \mathrm{nm}(\log \epsilon)\right): 211$ (4.71), 227 (4.66), 266 (4.48), 391 (4.02), 460 (sh, 2.92), 623 (2.78). Anal. Calcd for $\mathrm{C}_{61} \mathrm{H}_{59-}$ $\mathrm{CIF}_{6} \mathrm{NP}_{4} \mathrm{RuSb}$ : C, 56.26; $\mathrm{H}, 4.57 ; \mathrm{N}, 1.08$. Found: $\mathrm{C}, 55.92$; $\mathrm{H}, 4.51 ; \mathrm{N}, 1.07$.

trans-[CIRu(dppm) $\left.{ }_{2} \mathrm{C} \equiv \mathbf{C C}\left(\mathrm{NMeC}_{5} \mathrm{H}_{8}\right)=\mathrm{CH}_{2}\right]^{+} \mathrm{PF}_{6}{ }^{-}$(3g). This compound was prepared from cis- $\mathrm{RuCl}_{2}(\mathrm{dppm})_{2}(0.221 \mathrm{~g}$, $0.23 \mathrm{mmol}$ ), $\mathrm{NaSbF}_{6}(0.243 \mathrm{~g}, 0.94 \mathrm{mmol})$, and 1-methyl-1,2,5,6tetrahydropyridine $(110 \mu \mathrm{L})$ in o-dichlorobenzene as solvent. The suspension was stirred for 3 days under ambient conditions and then filtered. The solvent was then removed by vacuum distillation at $45^{\circ} \mathrm{C}$. The crude, oily product was repeatedly stirred with $10 \mathrm{~mL}$ portions of hexane and then dried to give crude $\mathbf{3 g}$ as a turqoise, powdery residue. This was loaded on a silica gel column and eluted with $\mathrm{CH}_{2} \mathrm{Cl}_{2} / \mathrm{CH}_{3^{-}}$ $\mathrm{CN}(8: 1)$ as a green band. After this band was dried under vacuum, $0.163 \mathrm{~g}(55.0 \%)$ was obtained as a green powder. ${ }^{1} \mathrm{H}$ NMR $\left(\mathrm{CD}_{3} \mathrm{CN}\right): \delta 1.83\left(\mathrm{~m}, \mathrm{br}, \mathrm{CH}_{2}, 2 \mathrm{H}\right), 2.13$ (s, NMe, 3H), 2.56 (oct, $\mathrm{CH}_{2} \mathrm{~N}, 3 \mathrm{~J}_{\mathrm{H}-\mathrm{H}}=4 \mathrm{~J}_{\mathrm{H}-\mathrm{H}}=6.2 \mathrm{~Hz}, 2 \mathrm{H}$ ), 3.02 (dvquint, $\mathrm{NCH},{ }^{2} \mathrm{~J}-\mathrm{H}=17.0 \mathrm{~Hz}$, 丁 $_{\mathrm{P}-\mathrm{H}}=2.5 \mathrm{~Hz}, 1 \mathrm{H}$ ), 3.33 (d mult br, $\left.\mathrm{NCH},{ }^{2} \mathrm{~J} \mathrm{H-H}=17.0 \mathrm{~Hz}, 1 \mathrm{H}\right), 3.82\left(\mathrm{~d} \mathrm{br}, \mathrm{C}=\mathrm{CHH},{ }^{2} \mathrm{~J} H-\mathrm{H}=3.0\right.$ $\mathrm{Hz}, 1 \mathrm{H}), 4.73(\mathrm{~d}, \mathrm{C}=\mathrm{CHH}$, 2 $\mathrm{H}-\mathrm{H}=3.0 \mathrm{~Hz}, 1 \mathrm{H}), 4.87$ (dvquint, $\mathrm{CH}_{2}$ (dppm), J $\mathrm{H}-\mathrm{H}=14.9 \mathrm{~Hz},{ }^{2} \mathrm{~J}_{\mathrm{P}-\mathrm{H}}=4 \mathrm{~J}_{\mathrm{P}^{\prime}-\mathrm{H}}=4.4 \mathrm{~Hz}, 2 \mathrm{H}$ ), 5.09 (dvquint, $\mathrm{CH}_{2}$ (dppm), $\mathrm{J} \mathrm{H}-\mathrm{H}_{\mathrm{H}}=14.9 \mathrm{~Hz},{ }^{2} \mathrm{~J} \mathrm{P}-\mathrm{H}=4 \mathrm{~J}_{\mathrm{P}^{\prime}-\mathrm{H}}=$ $4.6 \mathrm{~Hz}$ ), 5.33 (d mult, br, $=\mathrm{CH}, 3_{\mathrm{H}-\mathrm{H}}=10.3 \mathrm{~Hz}, 1 \mathrm{H}$ ), 5.70 (dhpt, $\left.=\mathrm{CH}, 3 \mathrm{~J}_{\mathrm{H}-\mathrm{H}}=10.3 \mathrm{~Hz}, 3 \mathrm{~J}_{\mathrm{H}-\mathrm{H}}=4 \mathrm{~J}_{\mathrm{H}-\mathrm{H}}=1.9 \mathrm{~Hz}, 1 \mathrm{H}\right)$, 7.19-7.30 (m, aryl H (dppm), 16H), 7.38 (m, aryl H (dppm), 8H), 7.46 (m, aryl H (dppm), 8H), 7.56 (m, aryl H (dppm), 8H ). ${ }^{13} \mathrm{C}\left\{{ }^{1} \mathrm{H}\right\} \mathrm{NMR}\left(\mathrm{CDCl}_{3}\right): \delta 22.6\left(\mathrm{NCH}_{2} \mathrm{CH}_{2}\right), 49.7$ (vquint, $\mathrm{CH}_{2}$ $\left.(\mathrm{dppm}), \mathrm{N}_{\mathrm{P}-\mathrm{C}}=11.1 \mathrm{~Hz}\right), 50.5\left(\mathrm{~N}\left(\mathrm{CH}_{3}\right)\right), 55.2(\mathrm{C} 3), 57.1,58.3$ $\left(\mathrm{NCH}_{2}\right), 95.7$ (vquint, J $\left.\mathrm{P}-\mathrm{C}=1.8 \mathrm{~Hz}, \mathrm{C} 2\right), 108.3\left(\mathrm{C}=\mathrm{CH}_{2}\right), 119.9$, $125.3(=\mathrm{CH}), 128.7,128.7,129.2,129.3,\left(\mathrm{~m}, \mathrm{~m}-\mathrm{C}_{6} \mathrm{H}_{5}\right), 130.67$, $130.76,130.86,130.94\left(\mathrm{p}-\mathrm{C}_{6} \mathrm{H}_{5}\right), 133.67,133.70,134.06,134.23$ $\left(\mathrm{m}, \mathrm{o}-\mathrm{C}_{6} \mathrm{H}_{5}\right), 134.84,135.02,136.44,136.65\left(\mathrm{~m}, \mathrm{ipso}-\mathrm{C}_{6} \mathrm{H}_{5}\right)$, 146.2 (vquint, $\mathrm{Cl}$, J $\mathrm{P}-\mathrm{C}=14.2 \mathrm{~Hz}) .{ }^{31} \mathrm{P}\left\{{ }^{1} \mathrm{H}\right\} \mathrm{NMR}\left(\mathrm{CDCl}_{3}\right): \delta$ -6.1 (AA'BB' spin system; $\mathrm{P}(\mathrm{dppm}))$. IR $\left(\mathrm{KBr} ; \mathrm{cm}^{-1}\right): v(\mathrm{C} \equiv \mathrm{C})$ $2037(\mathrm{~m}), v(\mathrm{C}=\mathrm{C}) 1602(\mathrm{~m}), 1585(\mathrm{w}), 1572(\mathrm{w}) . \mathrm{UV} / \mathrm{vis}\left(\mathrm{CH}_{3^{-}}\right.$ $\left.\mathrm{CN} ; \lambda_{\max }, \mathrm{nm}(\log \epsilon)\right): 228$ (4.80), 265 (4.56), 313 (4.00), 607 (2.74), 677 (2.55). Anal. Calcd for $\mathrm{C}_{60} \mathrm{H}_{57} \mathrm{ClF}_{6} \mathrm{NP}_{4} \mathrm{RuSb}: \mathrm{C}$, 55.93; H, 4.46; N, 1.09. Found: C, 54.94; H, 4.44; N, 1.15.

X-ray Crystallographic Analysis of $\mathbf{4 b}$. Table 2 reports details of the structure analysis for $\mathbf{4 b}$. An orange-red crystal of $\mathbf{4 b}$, obtained by crystallization from a $\mathrm{CH}_{2} \mathrm{Cl}_{2} /$ hexane mixture, was fixed with Nujol on top of a glass fiber and transferred to the cold stream of the low-temperature device of a Siemens P4 automated four-circle diffractometer. Cell constants were calculated from 52 well-centered reflections with $2 \theta$ angles ranging from 23.7 to $25^{\circ}$. Data were collected at $173 \mathrm{~K}$ using $\omega$-scans. Two check reflections measured at regular intervals showed no loss of intensity at the end of data collection. An empirical absorption correction based on $\psi$-scans was applied (12 reflections, maximum and minimum transmissi on factors 0.892 and 0.612 ). The structure was solved by direct methods, which revealed the positions of most of the non-hydrogen atoms. The missing ones were located in subsequent difference Fourier syntheses. Most of them were refined with anisotropic thermal parameters. The atoms $\mathrm{C} 4$, C5, C6, and C7, which are statistically disordered about two positions ( $f=0.57 / 0.43$ ) were refined with isotropic thermal parameters- equivalent bond lengths and angles were re strained to be equal within an arbitrary standard deviation of $0.01 \AA$. Hydrogen atoms were added at calculated positions and assigned isotropic displacement parameters equal to 1.2 $\left(\mathrm{CH}, \mathrm{CH}_{2}\right)$ or 1.5 times $\left(\mathrm{CH}_{3}\right)$ the $U_{\text {iso }}$ value of their respective parent carbon atoms and treated with appropriate riding models during the refinement.

Acknowledgment. R.F.W. wishes to acknowledge financial support of this work by the Deutsche Forschungsgemeinschaft, the F onds der Chemischen Industrie, and J ohnson\&Matthey for a generous loan of $\mathrm{RuCl}_{3}$. Collaboration between R.F.W. and S.Z. was sponsored by VW-Stiftung within the project on "I ntraand Intermolecular Electron Transfer".

Supporting Information Available: Tables of atom coordinates, thermal parameters, and bond lengths and angles for $\mathbf{4} \mathbf{b}$ and figures displaying the atomic displacement during the vibrations within the $2000-1500 \mathrm{~cm}^{-1}$ range. This material is available free of charge via the Internet at http://pubs.acs.org.

OM000925N 